h. IED

OCI U O 1995

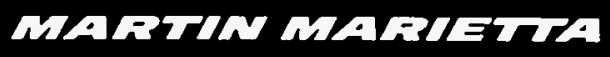

\section{WASTE \\ MANAGEMENT \\ PROGRAM}

OSTI

Pollution Prevention Opportunity Assessment for the K-25 Site Toxic Substances Control Act Incinerator Operations-Level III
MANAGED BY

MARTIN MARIETTA ENERGY SYSTEMS, INC.

FOR THE UNITED STATES

DEPARTMENT OF ENERGY 


\section{DISCLAIMER}

This report was prepared as an account of work sponsored by an agency of the United States Government. Neither the United States Government nor any agency thereof, nor any of their employees, makes any warranty, express or implied, or assumes any legal liability or responsibility for the accuracy, completeness, or usefulness of any information, apparatus, product, or process disclosed, or represents that its use would not infringe privately owned rights. Reference herein to any specific commercial product. process, or service by trade name, trademark, manufacturer, or otherwise, does not necessarily constitute or imply its endorsement, recommendation, or favoring by the United States Government or any agency thereof. The views and opinions of authors expressed herein do not necessarily state or reflect those of the United States Government or any agency thereof. 


\section{DISCLAIMER}

Portions of this document may be illegible in electronic image products. Images are produced from the best available original document. 
K-25 Waste Management Division

\title{
Pollution Prevention Opportunity Assessment for the K-25 Site Toxic Substances Control Act Incinerator Operations-Level III
}

Date Issued-September 1995

\author{
Prepared by \\ PAI Corporation \\ 116 Milan way
}

Oak Ridge, Tennessee 37830

under Support Services contract

to the U.S. Department of Energy

Contract number DE-AC05-88OR21794

Prepared for

U.S. Department of Energy

Office of Environmental Restoration and Waste Management under budget and reporting code EW 31

Environmental Management and Enrichment Facilities

Oak Ridge K-25 Site

Oak Ridge, Tennessee 37831-7101

managed by

LOCKHEED MARTIN ENERGY SYSTEMS, INC.

for the

U.S. DEPARTMENT OF ENERGY

under contract DE-AC05-84OR21400

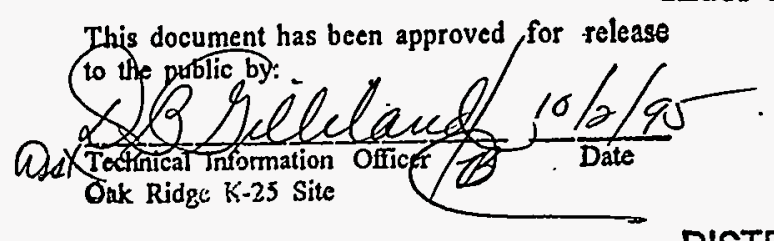




\section{CONTENTS}

TABLES $\ldots \ldots \ldots \ldots \ldots \ldots \ldots \ldots \ldots \ldots \ldots \ldots \ldots \ldots \ldots \ldots$

FIGURES $\ldots \ldots \ldots \ldots \ldots \ldots \ldots \ldots \ldots \ldots \ldots \ldots \ldots \ldots \ldots$

ACRONYMS AND ABBREVIATIONS $\ldots \ldots \ldots \ldots \ldots \ldots \ldots \ldots \ldots$ vii

EXECUTIVE SUMMARY $\ldots \ldots \ldots \ldots \ldots \ldots \ldots \ldots \ldots \ldots \ldots \ldots \ldots$

1. INTRODUCTION $\ldots \ldots \ldots \ldots \ldots \ldots \ldots \ldots \ldots \ldots \ldots \ldots \ldots \ldots \ldots$

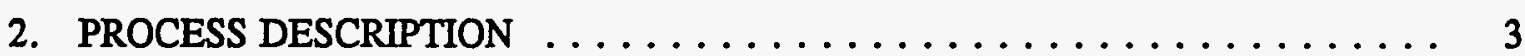

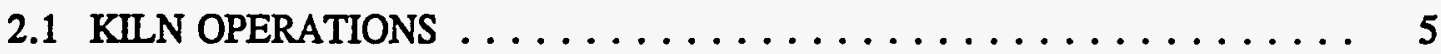

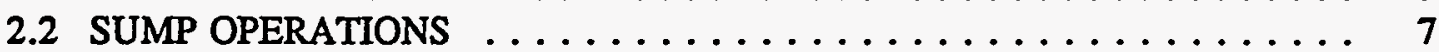

2.3 TANK AND TANKER OPERATIONS $\ldots \ldots \ldots \ldots \ldots \ldots \ldots \ldots \ldots$

2.4 TSCA INCINERATOR SITE OPERATIONS $\ldots \ldots \ldots \ldots \ldots \ldots \ldots$

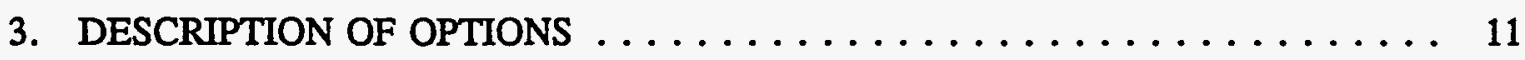

3.1 KILN OPERATIONS . . . . . . . . . . . . . . . . . . 11

3.1.1 Lower Kiln Temperature (Option 1) . . . . . . . . . . . . . 11

3.1.2 Reuse Drums for Waste Storage (Option 2) . . . . . . . . . . . . . 11

3.1.3 Recycle Activated Carbon (Option 3) . . . . . . . . . . . . 13

3.1.4 Use Protective Slag Lining . . . . . . . . . . . . . . . . 13

3.1.5 Reuse Refractory Brick ..................... 13

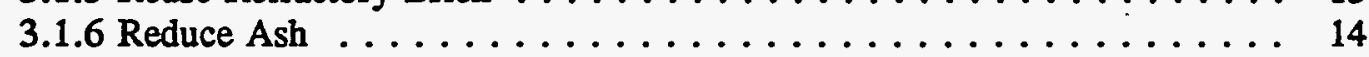

3.1.7 Reduce Air Emissions . . . . . . . . . . . . . . . . 14

3.2 SUMP OPERATIONS $\ldots \ldots \ldots \ldots \ldots \ldots \ldots \ldots \ldots \ldots \ldots \ldots \ldots$

3.2.1 Reuse Camera Cooling Water (Option 4) . . . . . . . . . . . 15

3.2.2 Reduce Quench Makeup Water (Option 5) . . . . . . . . . . . . 15

3.2.3 Control Algae in Firewater Sump (Option 6) . . . . . . . . . . . . 15

3.2 .4 Clarify Wastewater . . . . . . . . . . . . . . . . . . 15

3.2.5 Route Quench Purge to the IWS Sump . . . . . . . . . . . 16

3.2.6 Reduce Contamination of Rainwater ... . . . . . . . . . . 16

3.2.7 Reduce TSCA/IWS Sludge . . . . . . . . . . . . . . . 16

3.3 TANK AND TANKER OPERATIONS . . . . . . . . . . . . . 16

3.3.1 Pressure-wash and Decontaminate Tankers (Option 7) . . . . . . . . 17

3.3.2 Test Tankers with Liquid Waste (Option 8) and Inert Gas (Option 10) . . 17

3.3.3 Revise Tanker Decontamination Procedure (Option 9) . . . . . . . . 17

3.3.4 Recycle Activated Carbon (Option 3) . . . . . . . . . . . . . 18

3.3.5 Tanker Operations Options Not Considered Further . . . . . . . . 18

3.4 TSCA INCINERATOR SITE OPERATIONS $\ldots \ldots \ldots \ldots \ldots \ldots \ldots \ldots$

3.4.1 Substitute Metal Pallets for Wooden Pallets (Option 11) . . . . . . . . . 18

3.4.2 Substitute Metal Scaffolding for Wooden Scaffolding (Option 12) . . . . 19

3.4.3 Compact Final Waste Streams (Option 13) . . . . . . . . . . . . . . . 19

3.4.4 Provide Storage for Recovered Equipment (Option 14) . . . . . . . . . . 19

3.4.5 Options not Considered Further . . . . . . . . . . . . . . . . . 19 
4. ANALYSIS OF RECOMMENDED OPTIONS $\ldots \ldots \ldots \ldots \ldots \ldots \ldots \ldots$

$4.1 \mathrm{KILN}$ OPERATIONS ..................... 20

4.1.1 Lower Kiln Temperature (Option 1) . . . . . . . . . . . 20

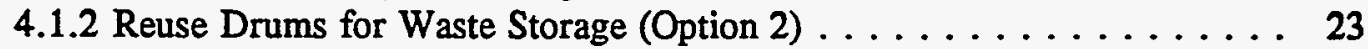

4.1.3 Recycle Activated Carbon (Option 3) $\ldots \ldots \ldots \ldots \ldots \ldots \ldots .24$

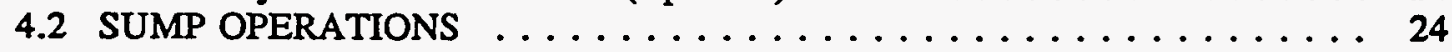

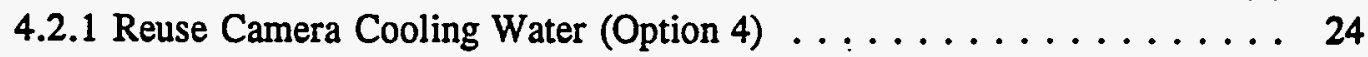

4.2.2 Reduce Quench MakeUp Water (Option 5) ............. 24

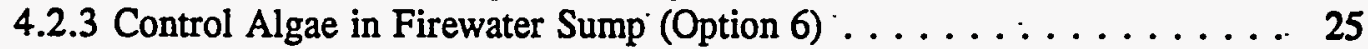

4.2.4 Clarify Wastewater .................... 25

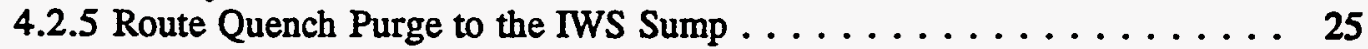

4.3 TANK AND TANKER OPERATIONS $\ldots \ldots \ldots \ldots \ldots \ldots \ldots \ldots 25$

4.3.1 Pressure-Washing and Decontaminate Tankers (Option 7) . . . . . 25

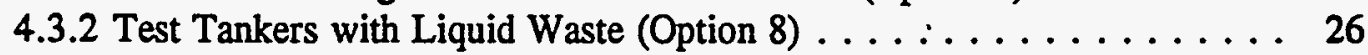

4.3.3 Recycle Activated Carbon (Option 3) .............. 26

4.3.4 Revise Tanker Decontamination Procedure (Option 9) . . . . . . 27

4.3.5 Test Tankers with Inert Gas (Option 10) $\ldots \ldots \ldots \ldots \ldots \ldots 27$

4.4 TSCA INCINERATOR SITE OPERATIONS $\ldots \ldots \ldots \ldots \ldots \ldots \ldots 27$

4.4.1 Substitute Metal Pallets for Wooden Pallets (Option 11) . . . . . . 27

4.4.2 Substitute Metal Scaffolding for Wooden Scaffolding (Option 12) . . . 28

4.4.3 Compact Final Waste Streams (Option 13) . . . . . . . . 28

4.4.4 Provide Storage for Recovered Equipment (Option 14) . . . . . . . . 29

5. IMPLEMENTATION PLAN AND FUNDING $\ldots \ldots \ldots \ldots \ldots \ldots \ldots$

6. CONCLUSIONS .......................... 39

6.1 KILN OPERATIONS ..................... 39

6.2 SUMP OPERATIONS $\ldots \ldots \ldots \ldots \ldots \ldots \ldots \ldots \ldots \ldots \ldots$

6.3 TANK/TANKER OPERATIONS . . .............. 40

6.4 TSCA INCINERATOR SITE OPERATIONS $\ldots \ldots \ldots \ldots \ldots \ldots \ldots 40$

7. REFERENCES $\ldots \ldots \ldots \ldots \ldots \ldots \ldots \ldots \ldots \ldots \ldots \ldots \ldots \ldots$

APPENDIX A. PPOA WORKSHEETS FOR KILN OPERATIONS $\ldots \ldots \ldots \ldots \ldots$ A-1

APPENDIX B. PPOA WORKSHEETS FOR SUMP OPERATIONS $\ldots \ldots \ldots \ldots$ B-1

APPENDIX C. PPOA WORKSHEETS FOR TANK/TANKER OPERATIONS $\ldots \ldots$ C-1

APPENDIX D. PPOA WORKSHEETS FOR TSCA SITE OPERATIONS $\ldots \ldots \ldots$ D-1

APPENDIX E. COST ESTIMATES AND CALCULATIONS $\ldots \ldots \ldots \ldots \ldots$ E-1 


\section{TABLES}

1.1 Waste stream summary $-1994 \ldots \ldots \ldots \ldots \ldots \ldots \ldots \ldots \ldots \ldots \ldots$

3.1 Summary of $\mathbf{P 2}$ options and impacts on waste generation $\ldots \ldots \ldots \ldots \ldots \ldots 12$

3.2 Tankers in use at TSCA Incinerator and WMD . . . . . . . . . . 17

4.1 Unit costs used for TSCA Incinerator P2 options evaluation $\ldots \ldots \ldots \ldots \ldots 21$

4.2 Cost information for TSCA Incinerator $\mathrm{P} 2$ options $\ldots \ldots \ldots \ldots \ldots \ldots 22$

5.1 TSCA Incinerator $\mathrm{P} 2$ recommended option implementation plan and funding . . . . 30

5.2 HiROI proposal ranking $\ldots \ldots \ldots \ldots \ldots \ldots \ldots \ldots \ldots \ldots \ldots \ldots \ldots \ldots$

6.1 Summary of TSCA Incinerator recommended P2 options $\ldots \ldots \ldots \ldots \ldots \ldots$

\section{FIGURES}

2.1. Process flow diagram for the TSCA Incinerator $\ldots \ldots \ldots \ldots \ldots \ldots$

2.2. Flow diagrams for four TSCA Incinerator process areas $\ldots \ldots \ldots \ldots \ldots \ldots 6$

2.3. Block flow diagram for sump operations $\ldots \ldots \ldots \ldots \ldots \ldots \ldots \ldots \ldots 8$

2.4. Process flow diagram for the current quench system $\ldots \ldots \ldots \ldots \ldots \ldots, 9$

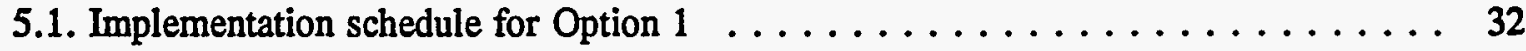

5.2. Implementation schedule for Option $2 \ldots \ldots \ldots \ldots \ldots \ldots \ldots \ldots \ldots \ldots \ldots$

5.3. Implementation schedule for Option $4 \ldots \ldots \ldots \ldots \ldots \ldots \ldots \ldots \ldots \ldots \ldots \ldots$

5.4. Implementation schedule for Option $5 \ldots \ldots \ldots \ldots \ldots \ldots \ldots \ldots \ldots \ldots \ldots \ldots$

5.5. Implementation schedule for Option $10 \ldots \ldots \ldots \ldots \ldots \ldots \ldots \ldots \ldots \ldots$

5.6. Implementation schedule for Option $12 \ldots \ldots \ldots \ldots \ldots \ldots \ldots \ldots \ldots \ldots . \ldots \ldots$

5.7. Implementation schedule for Option $14 \ldots \ldots \ldots \ldots \ldots \ldots \ldots \ldots \ldots$ 


\title{
ACRONYMS AND ABBREVIATIONS
}

\author{
CDR conceptual design report \\ CNF Central Neutralization Facility \\ CY calendar year \\ DOE U.S. Department of Energy \\ DOT U.S. Department of Transportation \\ EMD K-25 Site Environmental Management Division \\ EPA U.S. Environmental Protection Agency \\ ET\&I Engineering, Test, and Inspection \\ FEMP Fernald Environmental Management Project \\ FY fiscal year \\ GAC granular activated carbon \\ GCS gas cleaning system
HiROI high return on investment
HiVAL high value \\ IH industrial hygiene \\ IWS ionizing wet scrubber
}

KWTARS K-25 Waste Tracking and Reporting System

LMES Lockheed Martin Energy Systems, Inc.

LLW low-level waste

NA not applicable

NRC U.S. Nuclear Regulatory Commission

ORNL Oak Ridge National Laboratory

ORR Oak Ridge Reservation

\begin{tabular}{|c|c|}
\hline P2 & pollution prevention \\
\hline PCB & polychlorinated biphenyl \\
\hline PGDP & Paducah Gaseous Diffusion Plant \\
\hline PORTS & Portsmouth Gaseous Diffusion Plant \\
\hline PPOA & pollution prevention opportunity assessment \\
\hline PPE & personal protective equipment \\
\hline RAD & radioactive \\
\hline RCRA & Resource Conservation and Recovery Act of 1976 \\
\hline RKI & rotary kiln incinerator \\
\hline
\end{tabular}


ROI return on investment

SCC secondary combustion chamber

SOP standard operating procedure

SPP standard practice procedure

TSCA Toxic Substances Control Act

-TSS total suspended solids

WAC waste acceptance criteria

WMD K-25 Site Waste Management Division 
A Level III pollution prevention opportunity assessment (PPOA) was performed for the Oak Ridge K-25 Site Toxic Substances Control Act (TSCA) Incinerator to evaluate pollution prevention (P2) options for the following waste streams: TSCA Feed, TSCA Rinsewater, TSCA Trash, TSCA Solids, TSCA Ash, and TSCA/ionizing wet scrubber (IWS) Sludge. The main objective of this study was to identify and evaluate options to reduce the quantities of each waste stream generated by the TSCA Incinerator operations to realize significant environmental and/or economic benefits from P2.

For each of the waste streams, P2 options were evaluated following the U.S. Environmental Protection Agency (EPA) hierarchy to (1) reduce the quantity of waste generated, (2) recycle the waste, and/or (3) use alternate waste treatment or segregation methods. This report provides process descriptions, identification and evaluation of P2 options, and final recommendations. Seven of the fourteen evaluated options are being recommended for implementation; these are summarized in the table below, along with the associated return on investment (ROI). Identified options are presented in Sect. 3 and evaluated in Sect. 4. Implementation of the recommended options is addressed in Sect. 5, and conclusions from this study are presented in Sect. 6.

TSCA Incinerator P2 recommended options

\begin{tabular}{lrrr}
\hline \multicolumn{1}{c}{ Option } & $\begin{array}{c}\text { Annual } \\
\text { savings } \\
\text { (\$/year) }\end{array}$ & $\begin{array}{r}\text { Waste } \\
\text { reduction } \\
\text { (kg/year) }\end{array}$ & \% ROI \\
\hline Lower kiln temperature & 324,149 & 7,000 & NA $^{\mathrm{b}}$ \\
Reuse drums for waste storage & 204,816 & 31,230 & $\mathrm{NA}^{\mathrm{b}}$ \\
Reuse camera cooling water & 313,196 & $5,452,000$ & 1,413 \\
Reduce quench makeup water & 499,981 & $8,697,000$ & 41,665 \\
Test tankers with inert gas & 614,834 & 56,000 & 61,480 \\
Substitute metal scaffolding for wooden scaffolding & 44,312 & 6,552 & 39,312 \\
Provide storage for recovered equipment & 48,439 & 4,906 & 29,439 \\
\hline
\end{tabular}

- Annual savings is defined as gross annual savings (i.e., disposal, purchase, analytical, labor, etc.) less all gross annual operating costs. Implementation costs are not included in this definition.

b. Implementation cost for these options is zero; therefore, an ROI cannot be calculated.

When implemented, the seven recommended options are estimated to reduce the generation of waste by $14,223,458 \mathrm{~kg} /$ year through source reduction and by $31,230 \mathrm{~kg} /$ year through recycling. These options represent a cost savings of approximately $\$ 2,049,727 /$ year for the K-25 Site. The recommended P2 options were reviewed by TSCA Incinerator personnel. 


\section{INTRODUCTION}

The Toxic Substances Control Act (TSCA) Incinerator pollution prevention opportunity assessment (PPOA) was prepared for the K-25 Site P2 Program and funded by U.S. Department of Energy (DOE) Headquarters EM-334 block funding.

Level I PPOAs were prepared for the TSCA Incinerator in CY 1994, using CY 1993 data (LMES 1995b) and in accordance with DOE Model PPOA Guidance (DOE 1993). The waste description and CY 1994 quantities for each of the waste streams associated with the TSCA Incinerator are provided in Table 1.1. The waste stream with the highest ranking was TSCA Wastewater; a Level III PPOA was prepared for that stream in January 1995 (LMES 1995a). TSCA wastewater as addressed in this study is only that wastewater generated through leak/ pressure testing of tankers and does not include wastewaters discussed in the previous Level III PPOA. This report provides PPOAs on the six remaining TSCA Incinerator waste streams: TSCA Feed, TSCA Rinsewater, TSCA Trash, TSCA Solids, TSCA Ash, and TSCA/ ionizing wet scrubber (IWS) Sludge.

To facilitate the study, the TSCA Incinerator was subdivided into four process areas that encompass all six of the waste streams. These processes are described in Sect. 2 of this report.

Review of the existing processes, and identification and evaluation of $\mathrm{P} 2$ options, took place from March through June 1995, again using DOE Model PPOA Guidance. The main objectives of this PPOA were to evaluate options to reduce the amounts of the indicated waste streams, to recycle them, and/or to otherwise treat/manage the streams to achieve P2 goals. Several P2 options were identified for other TSCA Incinerator waste streams during this assessment.

The economic evaluations of P2 options (see Appendixes A-D, Worksheet 8; and calculations in Appendix E) include costs for both the disposal of wastewater at the Central Neutralization Facility (CNF) and the treatment of liquid wastes at the TSCA Incinerator itself. These costs were included at the direction of Energy Systems Waste Management Organization and in accordance with DOE guidance (DOE 1995). The cost figures used are included in Table 4.1 of this .PPOA. 
Table 1.1. Waste stream summary-1994:

\begin{tabular}{|c|c|c|c|c|}
\hline Waste stream & $\begin{array}{l}\text { KWTARS }^{b} \\
\text { number }\end{array}$ & $\begin{array}{l}\text { Quantity } \\
\text { (kg) }\end{array}$ & Type & Source \\
\hline \multicolumn{5}{|c|}{ Waste Streams in the Scope of Work } \\
\hline TSCA Rinse Waters & 178 & 0 & RCRA/RAD/PCB ${ }^{b}$ & (Not generated in 1994) \\
\hline TSCA Feed Materials & 159 & $108,000^{c}$ & $\mathrm{RCRA} / \mathrm{RAD}$ & $\begin{array}{l}\text { Diesel from rinsing and } \\
\text { decontamination of tankers }\end{array}$ \\
\hline TSCA Incinerator Ash & 85 & $1,165^{d}$ & RCRA/RAD & Incinerator operations \\
\hline TSCA Trash & 158 & 7,131 & $\begin{array}{l}\text { RCRA/RAD/PCB } \\
\text { RCRA/RAD }\end{array}$ & Maintenance and operations \\
\hline TSCA Solids & 162 & 16,988 & $\begin{array}{l}\text { RCRA/RAD/PCB } \\
\text { RCRA/RAD }\end{array}$ & Maintenance and operations \\
\hline TSCA IWS Sludge & 133 & $52,829^{d}$ & $\begin{array}{l}\text { RCRA/RAD } \\
\text { RCRA/PCB/RAD }\end{array}$ & Incinerator operations \\
\hline \multicolumn{5}{|c|}{ Additional Waste Streams } \\
\hline Air Emissions & none & 560 & RAD & $\begin{array}{l}\text { Incinerator, tank, and tanker } \\
\text { operations }\end{array}$ \\
\hline PCB Solids & 191 & 1,118 & PCB & Maintenance and operations \\
\hline TSCA Wastewatere & 148 & $56,000^{c, e}$ & $\begin{array}{l}\text { RCRA/RAD/PCB } \\
\text { RCRA/RAD }\end{array}$ & $\begin{array}{l}\text { Water from leak/pressure } \\
\text { testing of tankers }\end{array}$ \\
\hline LLW $W^{b}$ Solids & 201 & $496^{f}$ & RAD & Maintenance and operations \\
\hline LLW Wood/Lumber & 210 & $8,736^{d}$ & RAD & Maintenance and operations \\
\hline LLW Metals & 203 & $14,734^{d}$ & RAD & Maintenance activities \\
\hline LLW Refractory Brick & 201 & $22,000^{3}$ & $\mathrm{RAD}$ & Relining kiln \\
\hline
\end{tabular}

a All figures are derived from 1994 KWTARS (February 17, 1995, printout) unless otherwise specified.

${ }^{b} \mathrm{KWTARS}=\mathrm{K}-25$ Waste Tracking and Reporting System; RCRA = Resource Conservation and Recovery Act; $\mathrm{RAD}=$ radioactive; $\mathrm{PCB}=$ polychlorinated biphenyl; $\mathrm{LLW}=$ low-level waste.

c Mass of TSCA feed materials based on current process knowledge.

¿ Based on 1994 TSCA Incinerator waste generation data; "TSCA Waste Receipts Analysis by Category (sic)," received from G. Melton April 1995.

e $56,000 \mathrm{~kg}$ of this waste stream were generated from leak/pressure testing of tankers and, therefore, addressed in this study.

$f$ Based on 1993 KWTARS; 2/17/95 KWTARS printout did not address.

8 Based on 1994 and 1995 TSCA Incinerator waste generation data and current process knowledge. 


\section{PROCESS DESCRIPTION}

The TSCA Incinerator is a rotary kiln incinerator (RKI) designed to treat hazardous organic wastes, including RCRA wastes; polychlorinated biphenyl (PCB) waste; and low-level, uraniumcontaminated wastes. The incinerator is intended primarily for mixed waste treatment and is not intended to be used in competition with commercial TSCA/RCRA incineration. The facility, located in the K-1435 building complex on the east end of the K-25 Site, operates continuously. The incinerator handles wastes generated by DOE facilities, including the gaseous diffusion plants at Portsmouth, Ohio (PORTS), and Paducah, Kentucky (PGDP); the Y-12 Plant; the Oak Ridge National Laboratory (ORNL); the K-25 Site; and the Fernald Environmental Management Project (FEMP) in Ohio. The major waste streams treated to date can be categorized as oils, solvents and chemicals, and aqueous wastes. Solid wastes such as soils and spent carbon are stored for future incineration. Approximately $2,600,000 \mathrm{~kg}$ of waste and fuel oil were incinerated at the TSCA Incinerator during FY· 1994.

Incineration equipment includes the primary combustion unit, the mix chamber, the ash handling unit, and the secondary combustion chamber (SCC). The primary combustion chamber (rotary kiln) incinerates liquid organic and/or aqueous wastes fed from the liquid waste storage feed tanks. The mix chamber, which is located between the kiln and the SCC, collects the ash discharged from the rotary kiln. The hot flue gases are transferred into the secondary combustion unit. The SCC heats the flue gases from the mix chamber and burns organic liquid wastes. The combustion conditions established are adequate for the TSCA-compliant destruction of PCBs and the RCRA-compliant destruction of RCRA hazardous waste.

The off-gases from the SCC pass through a refractory-lined duct into the gas cleaning system (GCS). This four-stage treatment unit includes a quench chamber and a scrubber-treatment unit for gas cooling, removal of particulate matter, and removal of acid gas combustion byproducts. The IWS reduces both particulate emissions and acid gas discharges to the atmosphere to comply with federal, state, and local emission standards. The flue gases are vented by an induced-draft fan through the stack to the atmosphere. Sludge accumulates in the IWS throughout the year and is removed during annual maintenance outages.

A flow diagram of the current K-25 Site TSCA Incinerator operations is presented in Fig. 2.1. As is shown, liquid waste feed streams enter into either the rotary kiln or the SCC for incineration. Combustion conditions such as temperature, residence time, and excess air are controlled to ensure the complete combustion of organics in the waste feeds.

Water is used to quench hot gases from the SCC and to remove acid gases and particulate material in the GCS before the gas is vented to the atmosphere. Options for reducing the wastewater resulting from the quenching and gas cleaning operations were evaluated in the earlier wastewater PPOA study (LMES 1995a). 


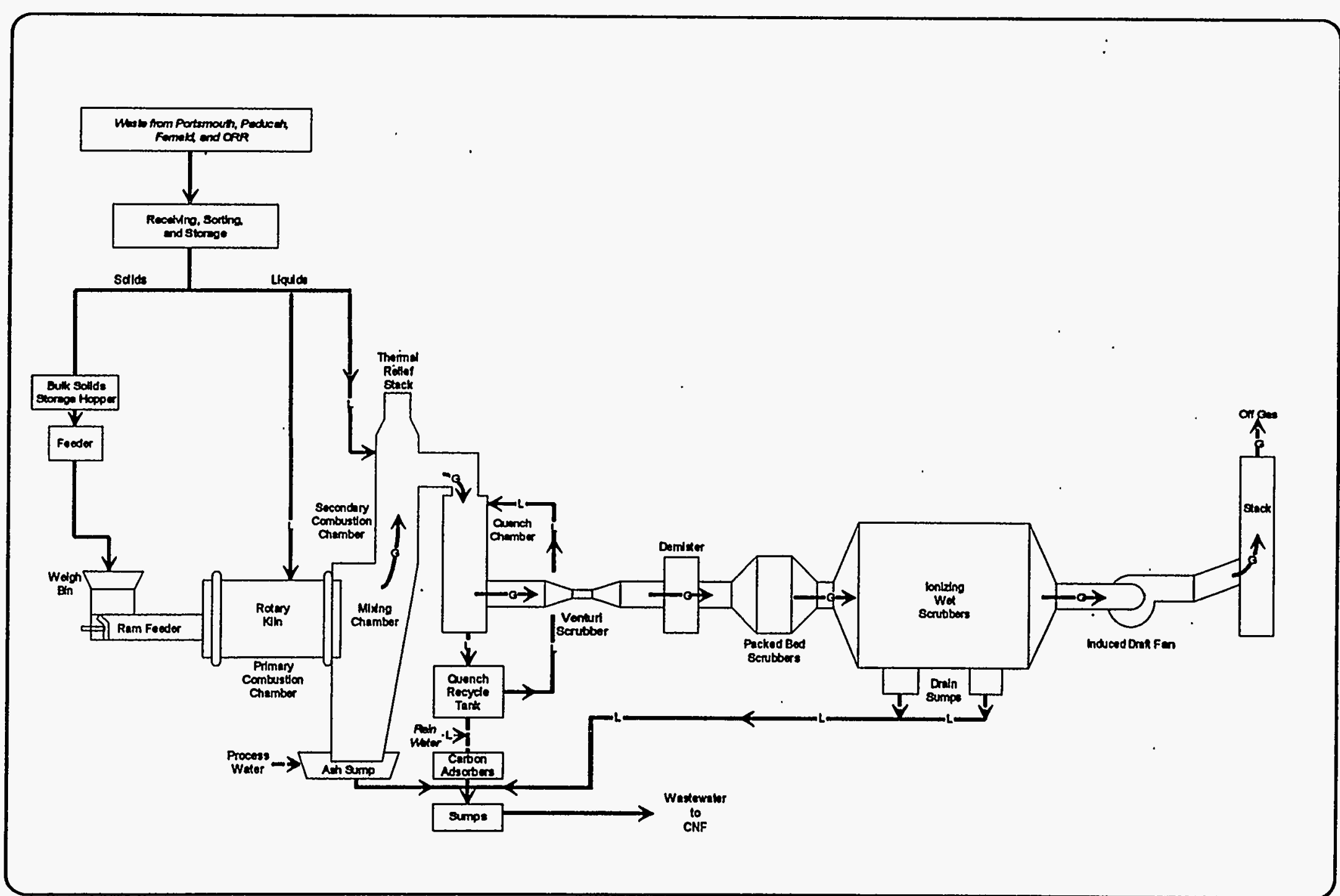

Fig. 2.1. Process flow diagram for TSCA Incinerator 
This assessment considers the waste streams to be generated from the four process areas of the TSCA Incinerator, as shown in Fig. 2.2. This approach follows the procedures outlined in the DOE Model PPOA Guidance and allows input of data into the standard worksheets. The four process areas are:

- kiln operations,

- sump operations,

- tank and tanker operations, and

- TSCA Incinerator site operations.

Kiln operations include the waste feed systems, the primary combustion chamber, and the ash handling system. Waste feed materials are introduced into the incinerator along with combustion air and auxiliary fuel, if required. Waste feeds currently consist of aqueous and organic liquids. Solid waste feeds are planned to begin this year and may include trash, soils, personal protective equipment (PPE), and granular activated carbon (GAC). Wastes produced during kiln operations include ash, used refractory bricks, and combustion gases with entrained fines.

Sump operations include processes occurring in the SCC, GCS, and wastewater sumps. Inputs to this process are firewater/rainwater, IWS sludge, scrubbing solution, and fresh GAC. Wastes produced during sump operations are exhaust gases (after scrubbing), spent carbon, IWS filter cake, and wastewater.

The third process considered in this assessment is tank and tanker operations. This process includes the TSCA feed materials and the TSCA rinsewater from the original six waste streams. Tank and tanker operations include pressure/leak testing of tanker trucks and tanks at the TSCA tank farm and cleaning and decontamination of the tanks and tankers. These operations result in contaminated water, diesel fuel, and sludges. Gas vents from the tanks in the tank farm also produce spent GAC.

The fourth process is TSCA Incinerator site operations. TSCA trash and solid waste are generated from TSCA Incinerator site-wide operations that utilize PPE, wood, rags, absorbents, and other debris that may be PCB- and/or radiologically contaminated. These wastes are generated on an intermittent basis but increase when the incinerator is shut down during maintenance outages.

\subsection{KILN OPERATIONS}

Two primary waste streams, TSCA ash and refractory brick, are generated from the kiln operations. Combustion air and combustion gases from the solid or liquid waste feeds pass through the primary combustion chamber (i.e., kiln) and into the SCC. Currently, only liquid wastes are treated in the rotary kiln. Combustion of the liquid wastes resulted in an ash waste stream of $1165 \mathrm{~kg}$ in CY 1994. When solid waste feeds are treated in the fall of 1995, the annual ash generation rate will increase significantly. Current plans are to feed a blend of soils and combustible solids (e.g., PPE, trash, etc.) to the kiln. Ash in the solid and liquid waste feeds is either discharged into the ash sump or entrained into the kiln off-gas as fines and removed downstream in the GCS as TSCA/TWS sludge. Ash in the ash sump is removed using a dragflight conveyor and is currently discharged into 55-gal drums for disposal. Because of the anticipated sharp increase in ash generation rate, TSCA Incinerator personnel are considering modifications 

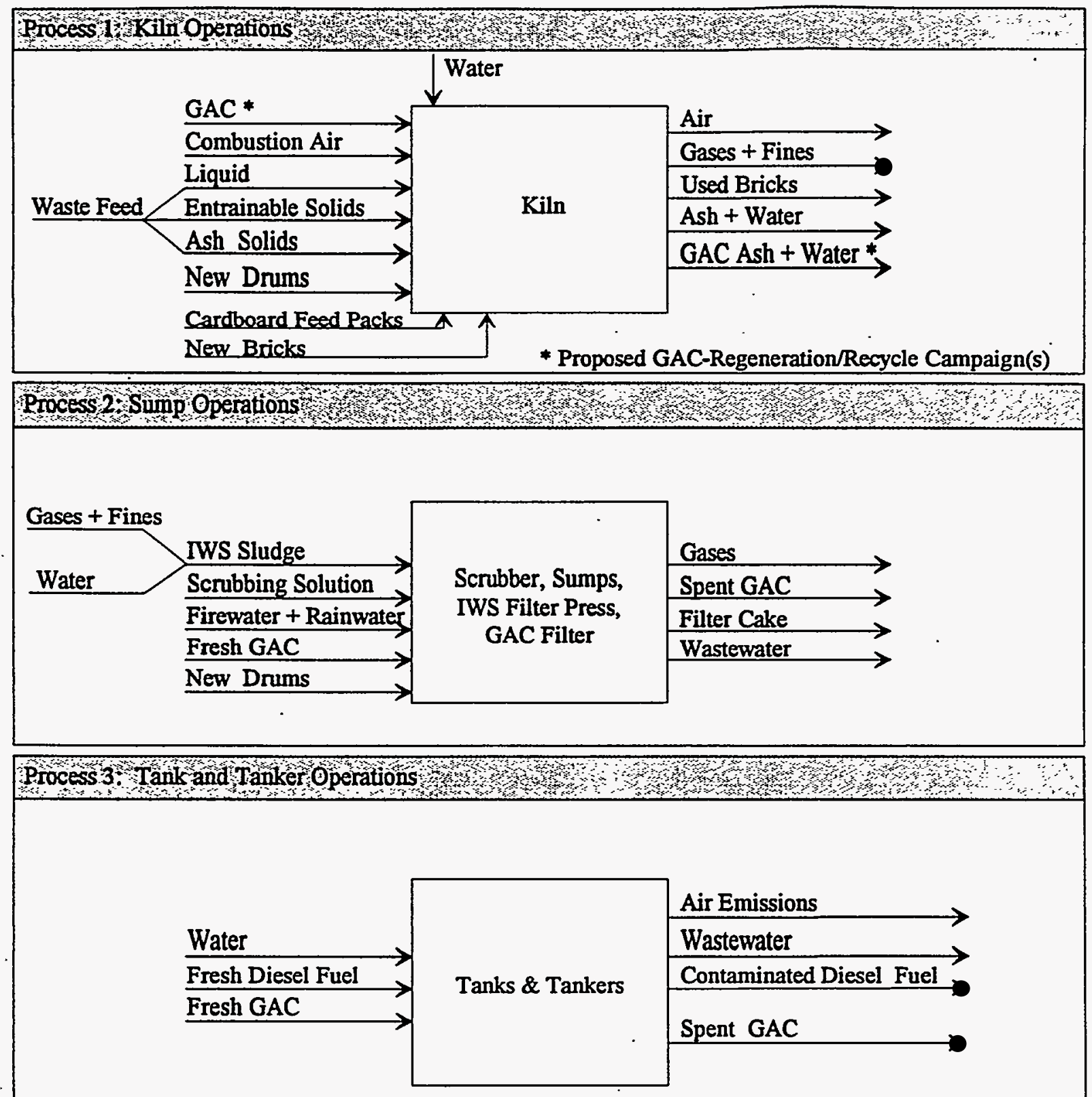

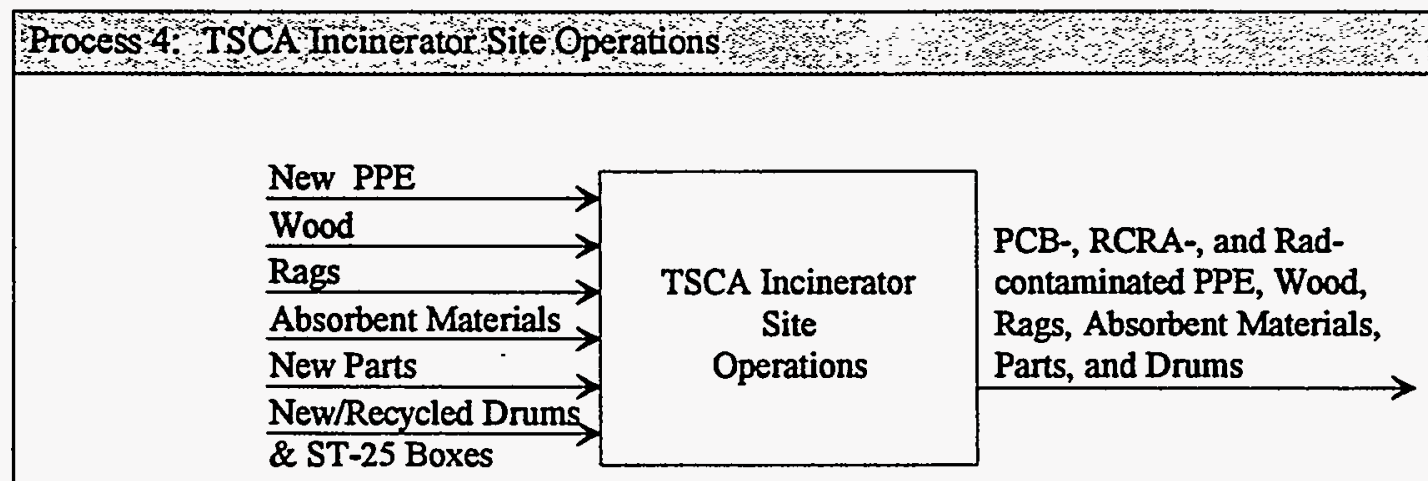


to the ash system to discharge the ash into containers. The ash is sampled and analyzed for PCBs. If the ash is less than 2 ppm PCB, it is no longer considered a TSCA-regulated waste. The ash remains a mixed (RCRA and radioactive) regulated waste.

The refractory brick lining of the kiln was repaired in the fall of 1994, generating 12,000 $\mathrm{kg}$ of brick waste, and subsequently rebricked in January 1995 , generating $32,000 \mathrm{~kg}$ of brick waste. The service life of brick in the kiln is $\sim 2$ years. Bricks are replaced for three principal reasons-chemical attack, spalling, and dislodging-resulting in an annual generation rate of $22,000 \mathrm{~kg}$. The bricks are chemically attacked by salts in the waste feed and acid gases $(\mathrm{HCl}$, $\mathrm{H}_{2} \mathrm{SO}_{4}$, etc.) generated from combustion of the wastes. Chemical attack causes pitting, etching, and general dissolution of the exposed brick surface lining. Spalling is the process of the brick surface flaking as a result of thermal (expansion) stresses in the brick. The third cause of brick failure is from bricks falling out of the lining. This failure is generally caused by space developing between the bricks because of thermal cycling (starting up and shutting down) and the associated brick expansion. The bricks are wedge-shaped, having a larger outer than inner radius. This wedge shape, when installed, forms an arched, circular lining inside the cylindrical kiln shell. When sufficient spacing develops between the bricks, they dislodge.

\subsection{SUMP OPERATIONS}

Sump operations (Fig. 2.3) include the ash sump, IWS sump, rainwater from the process area, firewater, and wastewater from the quench recycle tank. Hot gases from the SCC are quenched by water sprays in the quench chamber which decrease the temperature from $2200^{\circ} \mathrm{F}$ to about $180^{\circ} \mathrm{F}$, as indicated in Fig. 2.4. The quench off-gas passes through a venturi scrubber to remove acid gases and particulates. Water droplets in the gas from the venturi scrubber are removed by a wave-form-type demister before the gas enters the packed bed. The packed bed and IWS units further scrub the gas to remove acid gases and particulates before the gas is vented into the atmosphere. Wastewater purged from the GCS generates $87 \%$ of the wastewater discharged to the CNF. Water used for cooling the incinerator cameras and hydraulic equipment, which is discharged into the ash sump, amounts to about 2.1 million gallons (10\% of the total) annually and is the second largest source of incinerator wastewater generation.

Firewater and rainwater collected in diked areas around the incinerator equipment is the third source of incinerator. wastewater generation and accounts for about 0.7 million gal (about $3 \%$ of the total) annually. Part of the feed storage area is sheltered from rainfall; however, the rainwater is sometimes contaminated with PCBs from small oil leaks in the feed storage area where rain falls. Both the firewater and rainwater drain to a single sump, Tank 607. Waste discharged from Tank 607 is passed through the GAC filters before being discharged to the CNF. Spent GAC from these filters is drummed for processing in the TSCA Incinerator. The firewater system is tested twice per year to ensure system reliability; this test fills the 30,000-gal sump. The sump is emptied twice per month on average, resulting in an estimated annual amount of firewater and rainwater of 0.7 million gal, or an average of about $1 \mathrm{gpm}$.

The existing RCRA permit expires in September 1997. The new permit is expected to require a more stringent particulate emission standard, possibly as low as 0.005 grains per dry standard cubic foot (gr/dscf) rather than the $0.08 \mathrm{gr} / \mathrm{dscf}$ currently required. To meet the new RCRA air emission standard, modifications to the GCS are necessary. These modifications, 


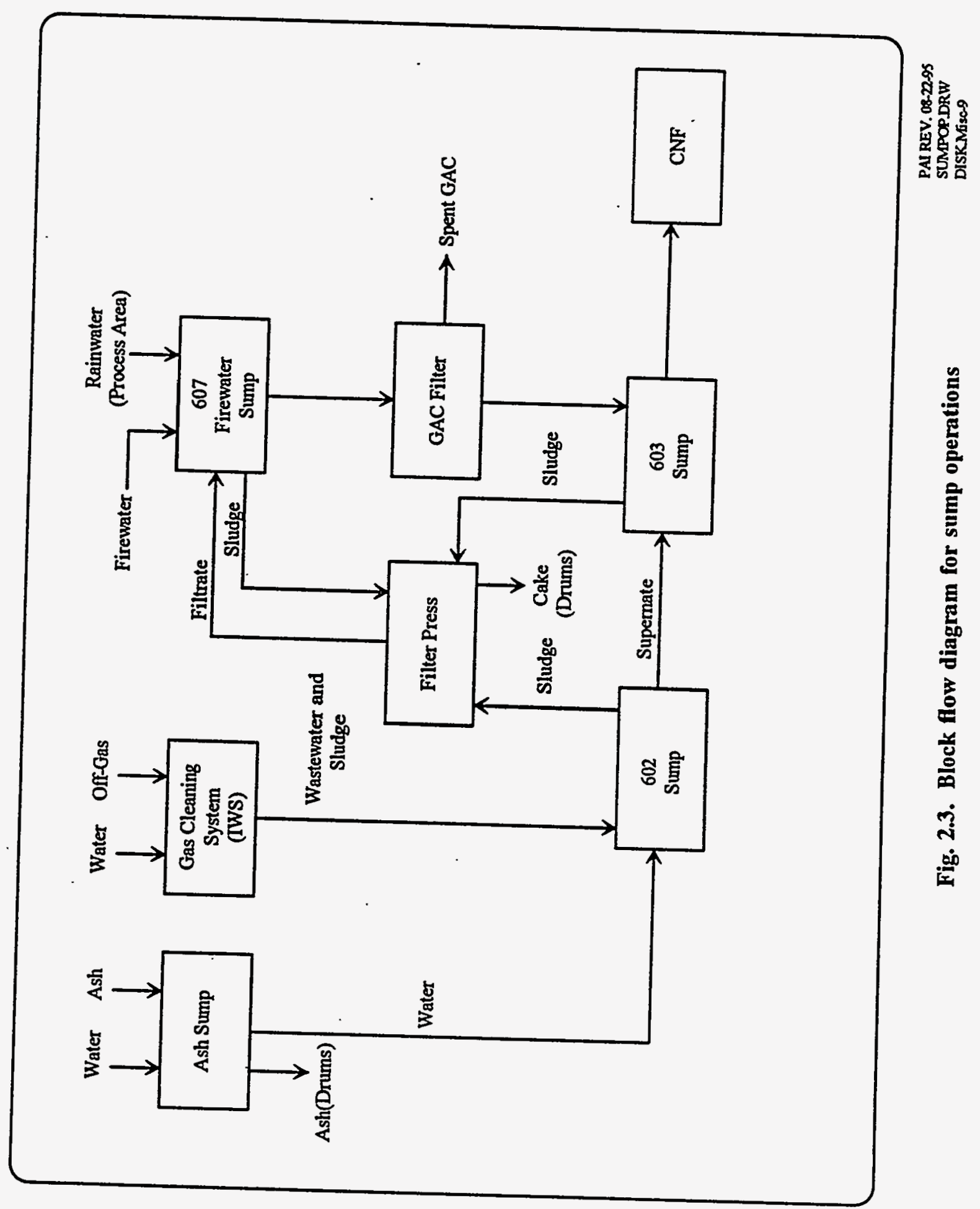




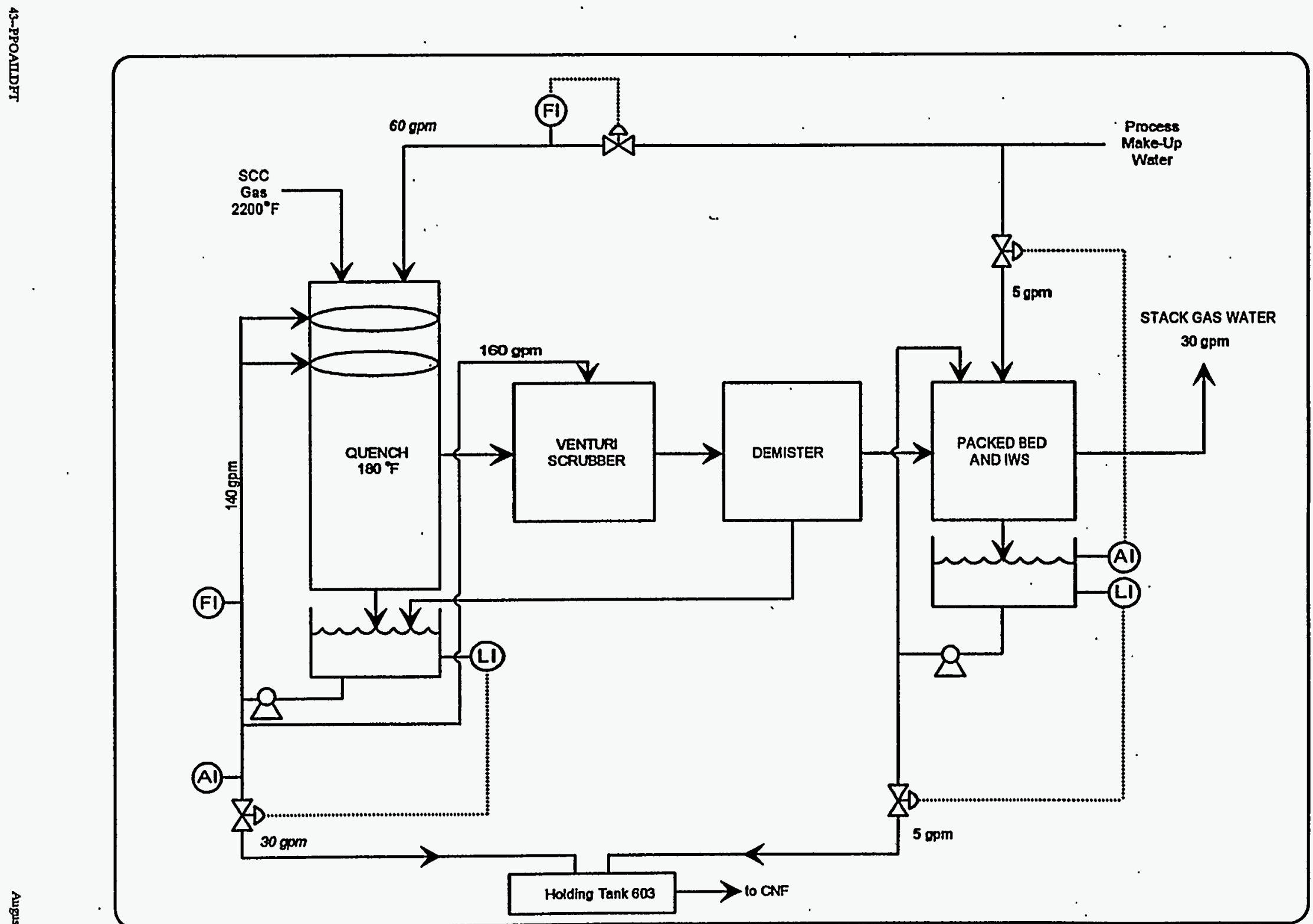


scheduled for implementation upon expiration of the RCRA permit, will include two IWS units to enhance particulate removal from the gas, thereby increasing the amount of sludge generated.

\subsection{TANK AND TANKER OPERATIONS}

Tanker trucks are decontaminated and tested at the tank farm. Decontamination of tankers is performed by rinsing three times with $400-600$ gal of diesel fuel. Tankers are decontaminated (1) by personnel from the Engineering, Test, and Inspection (ET\&I) Organization before annual internal inspections and (2) by TSCA Incinerator personnel before transporting RCRA-only wastes. All diesel rinseate removed from the tankers is treated in the TSCA Incinerator. In addition, tanker trucks are leak or pressure tested on an annual basis using 4000 or 6000 gal of water. This water is treated in the TSCA Incinerator.

Used PPE, diapers, and spill residue may also be generated during these operations. GAC is used at the facility to remove PCB gases vented from waste storage tanks during filling operations. GAC from the tank farm vents is removed from the filter housing and placed in drums separately for processing in the TSCA Incinerator.

\subsection{TSCA INCINERATOR SITE OPERATIONS}

Operation of the incinerator generates TSCA trash, TSCA solids, and PCB solids. These waste streams are generated intermittently from numerous points within the incinerator facility as a result of incinerator operations and maintenance. This stream represents $9 \%$ of the 1994 TSCA waste inventory. Trash and solids that may be PCB- or RCRA-radioactively contaminated include:

- respirators and cartridges,

- gloves and booties,

- Tyvek and Saranex suits,

- tarpaulins,

- G-flex,

- lumber (from scaffolding, sawhorses, and pallets),

- spill-control materials (rags, diapers, pigs, napkins, and booms), and

- contaminated equipment or parts from maintenance activities.

PPE is used in the process area to protect workers from contaminated surfaces, particulate matter, and vapors. Specific tasks require different levels of PPE for compliance with health and safety standards.

Wood, tarpaulins, and G-flex are used within the process area where they may become PCB-, RCRA-, and/or radioactively contaminated. Lumber is used primarily to construct scaffolding as part of maintenance operations during annual scheduled shutdowns. Wooden pallets are used to transfer and store drums in process areas and, upon contact with PCB waste, become PCB waste (by definition) and cannot be reused elsewhere. Likewise, G-flex and tarpaulins are placed under work areas during maintenance to prevent further contamination and also cannot be used at other maintenance locations at the Site. 


\section{DESCRIPTION OF OPTIONS}

This section describes all of the P2 options considered for the TSCA Incinerator. The P2 options considered are listed in Table 3.1. This table also provides a cross-reference to the appropriate appendix (i.e., A, B, C, or D), the name(s) of the waste stream(s) affected by the option, and the reduction in waste generation resulting from option implementation (in both kilograms per year and percent of total waste generation).

\subsection{KILN OPERATIONS}

The kiln operations generate two waste streams: kiln bricks and TSCA ash. Options for reducing these and other wastes are discussed below.

\subsubsection{Lower Kiln Temperature (Option 1)}

The primary combustion chamber is lined with refractory bricks that are replaced periodically. Waste generation can be reduced by extending the life of the bricks (thereby reducing the frequency of replacement). Several P2 options have been identified which will accomplish this; they are discussed below.

As stated in Sect. 2.1, there are three reasons for brick replacement: (1) chemical attack, (2) spalling, and (3) dislodging. A lower kiln temperature will reduce the effects of all three of these situations. Currently the kiln is operated at a temperature of $1850^{\circ} \mathrm{F}$ as measured by a thermocouple in the mix chamber between the kiln and the SCC. Because of the high kiln shell temperatures measured (up to $550^{\circ} \mathrm{F}$ ) and heat and mass balance modeling studies, it is believed that the actual temperature within the kiln is substantially higher (perhaps $2500^{\circ} \mathrm{F}$ ). Lower kiln temperatures (e.g., $1500^{\circ} \mathrm{F}$ ) will (1) reduce the chemical reaction rate of the brick with the acid gases and salts inherent in the wastes, (2) reduce the number of eutectic phase combinations formed in the presence of salts that will dissolve (i.e., melt) the refractory, and (3) reduce thermal expansion that results in spalling and increased spacing between bricks that may cause them to dislodge. Changing the kiln operating temperature is an option that can be incorporated into the permit renewal process currently under way. This option is recommended as Option 1 and is discussed further in Sect. 4.1.1.

\subsubsection{Reuse Drums for Waste Storage (Option 2)}

Ash from the combustion of wastes in the kiln is collected in the ash sump. This ash is currently placed in drums for storage and disposal. After appropriate washing, recycled drums from raw-material and waste storage could be used to store the ash. No current K-25 Site policy [e.g., standard practice procedure (SPP), standard operating procedure (SOP)] prohibits the reuse of waste storage containers. The K-25 Site Environmental Management Division (EMD) has been requested to evaluate the potential for reuse of drums to store ash. The use of plastic liners in waste-storage drums might allow reuse of the drums (subject to EMD approval). The K-25 Site Waste Management Division (WMD) is currently constructing a drum washing facility to decontaminate 
Table 3.1 Summary of $\mathbf{P 2}$ options and impacts on waste generation

\begin{tabular}{|c|c|c|c|c|c|}
\hline \multirow{2}{*}{$\begin{array}{c}\text { Option } \\
\text { Number } \\
\text { (worksheet) }\end{array}$} & \multirow[b]{2}{*}{ Option Name } & \multirow{2}{*}{$\begin{array}{l}\text { Name of Waste } \\
\text { Stream Affected }\end{array}$} & \multirow{2}{*}{$\begin{array}{c}\text { Current waste } \\
\text { generation } \\
\text { (kg/year) }\end{array}$} & \multicolumn{2}{|c|}{ Reduction in waste generation } \\
\hline & & & & $\mathrm{kg} /$ year & $\%$ \\
\hline 1 (A2) & Lower kiln temperature & LLW Refractory Brick & 22,000 & 7,000 & 32 \\
\hline $2(\mathrm{~A} 3)$ & Reuse drums for waste storage & $\begin{array}{l}\text { TSCA Solids } \\
\text { LLW Metals }\end{array}$ & $62,952^{a}$ & 31,230 & 50 \\
\hline 3 (A7) & Recycle activated carbon & TSCA Solids & 5,452 & $4,362^{b}$ & 80 \\
\hline $4(\mathrm{~B} 3)$ & Reuse camera cooling water & TSCA Wastewater & $75,000,000^{c}$ & $5,452,000$ & 7 \\
\hline $5(\mathrm{~B} 2)$ & Reduce quench makeup water & TSCA Wastewater & $75,000,000^{c}$ & $8,697,000$ & 12 \\
\hline 6 (B1) & Control algae in firewater sump & TSCA Solids & 5,452 & 1,262 & 23 \\
\hline $7(\mathrm{C} 7)$ & Pressure-wash and decontaminate tankers & TSCA Feed Materials & 108,000 & 71,280 & 66 \\
\hline $8(C 2)$ & Test tankers with liquid waste & TSCA Wastewater & 56,000 & 56,000 & 100 \\
\hline $9(\mathrm{C} 3)$ & Revise tanker decontamination procedure & TSCA Feed Materials & 108,000 & 21,600 & 20 \\
\hline $10(\mathrm{C} 1)$ & Test tankers with inert gas & TSCA Wastewater & 56,000 & 56,000 & 100 \\
\hline $11 .(\mathrm{D} 13)$ & Substitute metal pallets for wooden pallets & LLWW Wood/Lumber & 8,736 & 2,184 & 25 \\
\hline 12 (D12) & $\begin{array}{l}\text { Substitute metal scaffolding for wooden } \\
\text { scaffolding }\end{array}$ & LLW Wood/Lumber & 8,736 & 6,552 & 75 \\
\hline 13 (D2) & Compact final waste streams & TSCA Trash & 7,131 & 810 & 11 \\
\hline 14 (D1) & Provide storage for recovered equipment & LLW Metals & 14,734 & 4,906 & 33 \\
\hline
\end{tabular}

a The figure of $62,952 \mathrm{~kg}$ represents the anticipated weight of these two waste streams generated by TSCA Incinerator operations when solids are treated (i.e., FY 1996 and thereafter). The number includes CY 1994 TSCA Incinerator generation of the two streams plus the predicted additional weight of empty drums resulting from the solids campaign.

b Assuming non-implementation of Option 6; if Option 6 is also implemented, this waste reduction decreases to $3352 \mathrm{~kg} / \mathrm{year}$ (i.e., by $61 \%$ instead of $80 \%$ ).

c The figure of 75,000,000 kg/year of TSCA Wastewater was obtained from KWTARS for CY 1993. 
drums that stored TSCA wastes. The EPA currently requires drums that contained TSCA waste to be triple-rinsed before disposal. The spent drum rinseate is expected to be sent to the TSCA Incinerator for incineration. Empty drums that contained RCRA wastes are not regulated (except for acutely toxic wastes). These drums could be reused if washed. It is proposed that a similar drum-washing operation for RCRA empty drums be éstablished as part of the drum-washing operation at the WMD facility under construction. Contingent on K-25 Site support for a drum-reuse program, this option is recommended as Option 2 and is discussed further in Sect. 4.1.2.

\subsubsection{Recycle Activated Carbon (Option 3)}

GAC is one of the solid feeds expected to be treated in the incinerator. Recycling GAC was not only well received by existing generators at the Site, but it is reported by Calgon Carbon Corporation that recycled carbon is $92 \%$ as effective as source (virgin) carbon. Currently, there are several generators of GAC waste on the Oak Ridge Reservation (ORR). The regenerated carbon from each generator would be tested to ensure that the PCB concentration is below $2 \mathrm{ppm}$. This carbon could be processed in the incinerator for reuse, saving both disposal costs and cost of virgin product. The operating parameters of the incinerator would not be altered. Following the first regeneration, the carbon would be tested periodically to determine when it can no longer be used. Carbon stored before regeneration would meet all TSCA, RCRA, and radioactive storage requirements; treated carbon would be handled as a radioactive material. This option (Option 3) is discussed further in Sect. 4.1.3.

\subsubsection{Use Protective Slag Lining}

Another P2 option is the use of a protective slag lining in the kiln. The high operating temperatures in the kiln make it very likely that soil feeds will cause slag build-up on the kiln lining. A protective slag lining is used for specially designed slagging kilns that discharge a molten ash stream, and is also used in the steel industry. Such a lining would lower the actual temperature of the inner brick face and would, therefore, improve both the reliability and availability of the kiln operations. Although a slag lining for the TSCA Incinerator kiln using soil or sand may be technically feasible, such a lining would be very difficult to control and therefore not of practical benefit. Controlling the proper rate and blend of a variety of chemical waste feeds and determining proper operating temperature to form a uniform layer of slag so as to not damage the kiln are impráctical. For these reasons, a protective slag lining was not considered further and is not recommended.

\subsubsection{Reuse Refractory Brick}

When the kiln is rebricked (i.e., every 2 years) or brick repair work is performed, the bricks removed are usually damaged by either chemical attack or spalling. Some of the these bricks might be reusable, although removing the mortar may be difficult. Discussions with refractory vendors and experts indicated that reuse of refractory brick is not practiced. One reason given is that there was no known test method for determining the brick quality without destroying it. If simple, nondestructive test methods were developed, brick reuse would be technically feasible. At this time, this option is not considered further and is not recommended. 


\subsubsection{Reduce Ash}

Three options were identified but not considered further: compacting the feed, using low-ash feed boxes, and ash dewatering. Compacting the feed was initially considered for combustible solid feeds. Currently, it is expected that the combustible solid feed will be mixed with soil feeds, and compaction will not be required. The feed boxes selected already have a low ash content. Dewatering the ash (by mechanical and/or thermal process) would not reduce the volume of the ash because of its relatively large particle size distribution. None of these three options were considered further.

\subsubsection{Reduce Air Emissions}

In addition to solid and liquid waste streams, air emissions at the TSCA Incinerator were also evaluated as part of this study. The primary air-emission sources are the incinerator stack and the vents from both tanks and tanker trucks. All air emissions are currently in compliance with all applicable RCRA, TSCA, and Clean Air Act requirements. The GCS is planned to be upgraded in 1998 to meet new, more stringent regulatory requirements expected to be imposed in September 1997 (i.e., after expiration of the existing RCRA permit).

Current stack emission levels (as measured during the 1989 RCRA/TSCA trial burn) were, on average, $0.025 \mathrm{gr} / \mathrm{dscf}$. The GCS upgrade is designed to achieve a stack particulate loading below $0.01 \mathrm{gr} / \mathrm{dscf}$, which represents a $60 \%$ reduction in the particulate emissions. This upgrade will also reduce other metal particulate air emissions, but these reductions have not been calculated to date. No further recommendations to reduce stack emissions are proposed at this time.

Tank emissions are presently vented through GAC filters; no options are being considered to further reduce these emissions. According to the TSCA Incinerator regulatory specialist, tanker emissions during loading do not currently require control but might become regulated later in 1995. Accordingly, the addition of 55-gal drums of GAC to tankers (similar to those used for the tank vent system) is recommended when these regulations are promulgated.

\subsection{SUMP OPERATIONS}

The sump operations generate the following waste streams: TSCA Wastewater, TSCA/IWS Sludge, and GAC. Options to reduce these wastes are discussed below.

TSCA Wastewater, at nearly 24 million gal in FY 1994, is the largest waste stream generated by the TSCA Incinerator facility. Although this waste stream was evaluated in a previous PPOA report (LMES 1995b), several new options for reducing it have been identified. The earlier recommended option to upgrade the quench recycle system to reduce wastewater (by up to $80 \%$ ) will be incorporated into the GCS Upgrade project scheduled to be implemented in 1998. Two of the new options for reducing wastewater are applicable only to the interim 2-year time period before the GCS Upgrade project is implemented.

The options identified to reduce the TSCA wastewater stream are (1) use the cooling water to the SCC camera also for the kiln camera, (2) reduce the quench makeup water rate when not feeding wastes, (3) re-route the quench purge water to be used as makeup water for the IWS 
sump, (4) clarify influent to Tanks 602A and 602B to control the suspended solid level, and (5) decontaminate storm drains and equipment to reduce PCB contamination of rainwater.

\subsubsection{Reuse Camera Cooling Water (Option 4)}

The first option, to reroute the camera cooling water, is similar to a recommendation made in the earlier TSCA Wastewater PPOA study. Implementation of the earlier option was planned during the GCS Upgrade. Currently, about $3 \mathrm{gpm}$ (1.4 million gal per year) of cooling water is used for each camera. A simpler option that can be implemented immediately is to use the same cooling water for both the SCC and kiln camera, saving 1.4 million gal of water per year. It is conservatively estimated that the camera cooling duty is less than $10,000 \mathrm{Btu} / \mathrm{hr}$, which is the rate of heat transfer to $1 \mathrm{ft}^{2}$ of the solid bed in a hot kiln. This duty currently increases the cooling water temperature about $6^{\circ} \mathrm{F}$ in each camera, and routing this water to the next camera would not result in its overheating. This option is recommended as Option 4 and is discussed further in Sect. 4.2.1.

\subsubsection{Reduce Quench Makeup Water (Option 5)}

The second option, to reduce the quench makeup water rate when not incinerating wastes, requires procedural approval and change of an interlock value in the incinerator process logic. Currently, a reduced rate of $35 \mathrm{gpm}$ of quench makeup water is allowed only when the SCC natural gas burner firing rate is below $6000 \mathrm{scfm}$ (about 6 million Btu/hr). Above this setpoint, the makeup water rate is increased to $60 \mathrm{gpm}$. It is recommended that a higher interlock setpoint (e.g., 15,000 scfm) be evaluated to allow start-up and stand-by operation when not feeding wastes. This option is estimated to reduce the wastewater discharge when not feeding wastes from $60 \mathrm{gpm}$ to $35 \mathrm{gpm}$, or by 4.0 million gal per year (until the GCS Upgrade is implemented). This option is recommended as Option 5 and is discussed further in Sect. 4.2.2.

\subsubsection{Control Algae in Firewater Sump (Option 6)}

One option was identified for reducing the generation rate of spent GAC from the firewater sump. GAC is considered "spent" when (1) organic breakthrough occurs in the sump effluent or (2) physical blockage of the GAC bed occurs. The latter situation often results from the buildup of algae in the sump. Two measures were evaluated to minimize algae buildup: addition of an algaecide to either the sump itself or its influent and covering the sump to block sunlight. The latter option (Option 6 ) is discussed further in Sect. 4.2.3:

\subsubsection{Clarify Wastewater}

The GCS Upgrade will reduce the volume of wastewater from about $40 \mathrm{gpm}$ to less than 20 gpm. Unfortunately, this flow reduction might bring about an increase in total suspended solids (TSS) such that the $270 \mathrm{ppm}$ limit [which is mandated by the CNF waste acceptance criteria (WAC)] is exceeded. TSCA Operations will then have two choices: (1) either increase the flow of make-up water entering the system, thus meeting the TSS WAC via dilution, or (2) enhance clarification capability over and above that currently provided by the sumps. The latter option considers the use of a clarifier to remove TSS to meet the CNF limit. No recommendation on this option will be made at this time because of the lack of data on the future wastewater TSS level; however, use of a clarifier is discussed further in Sect. 4.2.4. 


\subsubsection{Route Quench Purge to the IWS Sump}

The third option, to reroute the quench purge to the IWS sump, would eliminate the need for make-up water to the IWS sump. This option is estimated to reduce the wastewater discharge by 1.7 million gal per year (until the GCS Upgrade is implemented). This option is believed by the TSCA Incinerator regulatory specialist to require a permit modification and public notification. Because of the extended time periods needed for previous regulatory review (i.e., up to several years), this option is not recommended. However, further discussion is provided in Sect. 4.2.5.

\subsubsection{Reduce Contamination of Rainwater}

Two options for reducing the contamination of rainwater collected from the incinerator process areas were identified. The first option is to decontaminate the storm drain contaminated from previous waste liquid spills. This option involves recycling solvent cleaner through the underground drain system; however, further study indicated that this option is not likely to effectively decontaminate the drains and therefore would not reduce the amount of contaminated water. The second option, to decontaminate process equipment areas to prevent rainwater contamination, further relies on cleaning the drains, and it is therefore not feasible to decontaminate the process equipment. Neither of these options is recommended, and neither is considered further. ${ }^{1}$

\subsubsection{Reduce TSCA/IWS Sludge}

Two options for reducing the quantity of TSCA/TWS sludge were identified. The first option is to reuse drums to store the filter cake from the sludge. This option is recommended and discussed further in Sect. 4.1.2. The second option was to further reduce the water content in the TSCA/IWS filter cake. This option was considered a waste management activity, not a P2 activity to reduce the amount of waste generated. TSCA Operations is reviewing the filter press operations to determine if the filter cake can be dewatered further. This option was not considered further.

\subsection{TANK AND TANKER OPERATIONS}

WMD owns two tanker trucks, each with a capacity of 6200 gal (see Table 3.2). The vacuum tanker (E112178) is used to haul both PCB and non-PCB wastes; the other tanker (E112177) is reserved for aqueous non-PCB wastes. Leak/pressure testing is done at the TSCA tank farm by ET\&I personnel. The TSCA Incinerator Division owns three tanker trucks (E112193, 8619, and 8620). Tanker 8619 is used for non-PCB wastes, Tanker 8620 is used only for PCB wastes, and E112193 is used for both types of waste. These tankers are decontaminated and pressure tested at the TSCA Incinerator facility. In addition, TSCA Incinerator personnel periodically decontaminate tankers with three 600 -gal (or $10 \%$ by volume) diesel fuel rinses so that non-PCB waste loads can be hauled without cross-contamination.

\footnotetext{
${ }^{1}$ TSCA Operations is planning to decontaminate the firewater sump to reduce the contamination level of the sump water.
} 
Table 3.2. Tankers in use at TSCA Incinerator and WMD

\begin{tabular}{lllc}
\hline \multicolumn{1}{c}{ Tanker no. } & \multicolumn{1}{c}{ Owner } & \multicolumn{1}{c}{ Use } & Volume (gallons) \\
\hline E112193 & TSCA Incinerator & PCB/Non-PCB & 6,200 \\
8619 & TSCA Incinerator & Non-PCB & 4,000 \\
8620 & TSCA Incinerator & PCB & 4,000 \\
E112178 & WMD & PCB Non-PCB & 6,200 \\
E112177 & WMD & Non-PCB & 6,200 \\
\hline
\end{tabular}

\subsubsection{Pressure-wash and Decontaminate Tankers (Option 7)}

One method for reducing generation of PCB-contaminated diesel fuel is to use a recirculating pressure washer to decontaminate the tankers instead of using three 600-gal rinses. TSCA regulations (40 CFR 761.79) allow reuse of solvent for decontamination until the PCB concentration exceeds $50 \mathrm{ppm}$. Each rinse of the tanker would be accomplished by recirculating diesel fuel from one 600 -gal tank. This fuel would be reused for subsequent rinses until the PCB concentration exceeded $50 \mathrm{ppm}$. This determination could be made based on process knowledge and/or field testing, and the equipment is available commercially. This method would reduce generation of contaminated diesel fuel from decontamination activities and will be discussed in Sect. 4.3.1.

\subsubsection{Test Tankers with Liquid Waste (Option 8) and Inert Gas (Option 10)}

Presently, each tanker truck used to haul only DOT hazardous material must undergo pressure/leak tests to verify integrity. The leak test is performed annually, and the pressure retest is performed every 5 years or annually in some cases. Each tanker, after undergoing decontamination by ET\&I, is filled with water to perform the test. The water is ultimately treated in the incinerator. Two alternatives to this procedure are (1) use PCB waste as the liquid to perform the hydrostatic test or (2) use a pneumatic test with an inert gas. Both of these alternatives are allowable under U.S. Department of Transportation (DOT) regulations [49 CFR $180.407(\mathrm{~g})]$ and will eliminate $\mathrm{PCB}$-contaminated water as a waste stream. Both of these options (Options 8 and 10) are discussed in Sects. 4.3.2 and 4.3.5, respectively.

\subsection{3 - Revise Tanker Decontamination Procedure (Option 9)}

The tankers are decontaminated even though the RCRA wastes will be combined with other TSCA wastes. This decontamination is performed to reduce the quantity of PCB reportable waste. Before hauling mixed or RCRA waste liquids for treatment at the TSCA Incinerator, PCBcontaminated tanker trucks are decontaminated at the TSCA Incinerator facility. The procedure for this operation specifies that the tanker undergo three rinses of about 600 gal each $(10 \%$ of the tanker volume) of clean diesel fuel. Decontamination of the tanker trucks is also performed as a safety measure before the annual inspection of their interiors and before leak testing to limit PCB contamination in the test water; these decontaminations and inspections are performed by ET\&I. Changes in these decontamination procedures (Option 9) will be discussed in Sect. 4.3.4. 


\subsubsection{Recycle Activated Carbon (Option 3)}

GAC is used in the tank farm vents to capture volatile emissions. This carbon could be processed in the incinerator for reuse, as discussed in Sect. 3.1. The regenerated carbon would be tested to ensure that the PCB concentration is below $2 \mathrm{ppm}$ and would be tested periodically to determine its remaining adsorptive capacity. Carbon stored before regeneration would meet all TSCA, RCRA, and radioactive storage requirements; treated carbon would be handled as a radioactive material. This option is recommended and is discussed in Sect. 4.1.3.

\subsubsection{Tanker Operations Options Not Considered Further}

Control of spills during tanker unloading operations is currently addressed in TSCA Incinerator procedures. Standardization of spill control techniques during unloading is not practical because of differences in tanker configurations, unloading pumps, and waste characteristics (e.g., solids content, viscosity, $\mathrm{PCB}$ concentration, flash point). Because of the infrequency of spills and the small volumes of waste generated during each episode, this option will not be considered further.

Optimizing the scheduling of tanker loads by grouping PCB and non-PCB wastes could result in fewer tanker decontaminations and thus reduce waste. If PCB loads are hauled consecutively instead of intermittently, a reduction can be realized. Because of the uncertainty of waste availability, however, this option will not be considered further.

Several other options are available for reducing diesel fuel use from tanker decontamination. These options include changing from diesel fuel to another solvent, reducing the rinse volume below $600 \mathrm{gal}$, and using waste diesel fuel from another source instead of clean diesel fuel. Each of these options has regulatory or institutional impediments to implementation or is impractical in light of other options. Therefore, none of these options are recommended nor are they discussed in Sect. 4.

\subsection{TSCA INCINERATOR SITE OPERATIONS.}

Five P2 options have been considered for reducing generation of PCB/radioactively contaminated solids at the incinerator. These options are to:

- purchase either metal or plastic pallets for use in place of wood pallets,

- purchase metal scaffolding for use in place of wood scaffolding,

- rent metal scaffolding for use in place of wood scaffolding,

- compact certain solid wastes in drums before disposal, and

- provide equipment-storage facilities to enable reuse of contaminated equipment.

\subsubsection{Substitute Metal Pallets for Wooden Pallets (Option 11)}

Metal or plastic should be substituted for wood in pallets, sawhorses, and scaffolding. The wooden pallets currently supplied through central stores absorb liquid contamination and are not readily decontaminated or easily incinerated. It is projected that plastic pallets have five times the life of wooden ones, can be more easily decontaminated and incinerated, and cost significantly less for disposal (because of both their lower ash content and the absence of nails). These substitutions will result in reduction of low-level waste lumber. 
To use metal or plastic pallets, both a change in procedure and the creation of an extended transition zone are necessary. Once these changes are made, a controlled pallet may be taken to a material transfer area or transition zone and receive materials packed in nonprocess containers. The reduction in pollution realized from switching from wooden to plastic pallets is at least $2184 \mathrm{~kg} / \mathrm{year}$. This option is discussed further in Sect. 4.4.1.

\subsubsection{Substitute Metal Scaffolding for Wooden Scaffolding (Option 12)}

Wooden scaffolds are used during maintenance operations in several locations within controlled areas. A change from wooden scaffolds to metal ones in process areas could result in a pollution savings of approximately $6552 \mathrm{~kg} / \mathrm{year}$ (according to 1994 waste-generation data). A metal scaffold is available that can be used, disassembled, and relocated into other process areas. This type of scaffold is accepted throughout the nuclear industry and is readily decontaminated. The scaffolding-replacement option (Option 12) is discussed in Sect. 4.4.2.

\subsubsection{Compact Final Waste Streams (Option 13)}

Compaction of solid waste within drums will reduce the number of drums and therefore reduce the reported waste quantity and the disposal cost of the wastes. This option (Option 13) is discussed further in Sect. 4.4.3.

\subsubsection{Provide Storage for Recovered Equipment (Option 14)}

An option to store and reuse contaminated equipment would reduce the quantity of scrap metal waste generated by up to $33 \%$. Often an entire piece of equipment is thrown out instead of replacing a few parts. Storage of this equipment would allow for its future repair and reuse. PCB capacitor shipment boxes are recommended for equipment storage. These boxes $(6 \times 3 \times$ $3 \mathrm{ft}$ ) are designed for PCB-contaminated equipment storage. This option (Option 14) is recommended and discussed further in Sect. 4.4.4.

\subsubsection{Options not Considered Further}

Reuse of spill response materials was an option initially considered. Absorbent pads and other materials that are not saturated could be reused after removal of the contaminated portions. This option was not considered further and is not recommended because of the difficulty of determining the extent of contamination.

An option to reuse respirators was considered. The K-25 Health and Safety Department had previously reviewed and rejected this option because it would require a Site-wide change in policy and raise concerns of impacting worker health and safety and because of the high cost of implementing a site testing and cleaning program. This option was not considered further. 


\section{ANALYSIS OF RECOMMENDED OPTIONS}

The economic evaluations of P2 options (see Appendices A-D, Worksheet 8; and calculations in Appendix E) include costs for both the disposal of wastewater at the Central Neutralization Facility (CNF) and the treatment of liquid wastes at the TSCA Incinerator itself. These costs were included at the direction of Energy Systems Waste Management Organization, and in accordance with DOE guidance (DOE 1995). The cost figures used are included in Table 4.1 of this PPOA.

A complete set of worksheets was developed for each of the four processes under consideration. Calculations of waste quantities and costs for each of the four processes are presented in Appendix E. All P2 options that were generated are included on Worksheets 6, Appendixes A, B, C, and D. The screening of potential options is documented on Worksheets 7. The options for which cost estimates and weighted scoring were completed are listed in Table 4.2. Each option is discussed in turn in the following sections.

\subsection{KILN OPERATIONS}

Three options for kiln operations are recommended to reduce brick and ash waste quantities: (1) lower kiln temperature, (2) reuse drums, and (3) recycle activated carbon. Considerations, including the purchase and implementation cost, disposal cost, cost savings, and Return on Investment (ROI), will be discussed for each option.

\subsubsection{Lower Kiln Temperature (Option 1)}

No cost is estimated for implementing the option to lower the kiln temperature. This option would be incorporated as part of the RCRA/TSCA trial burn activity. An earlier implementation schedule for this option would require a new trial burn. Because the current RCRA permit expires in September 1997, the request for permit renewal is scheduled for submission in March 1996. To implement this option, a lower (minimum) kiln operating temperature would be indicated in the renewal application. The results of the trial burn will indicate whether a lower temperature will enable the incinerator to meet the destruction and removal efficiencies dictated by both RCRA and TSCA. However, the kiln might have to be operated above the new minimum temperature to ensure ash quality (i.e., $<2 \mathrm{ppm} \mathrm{PCB}$ ).

The TSCA Incinerator kiln was rebricked in 1995, with an expected brick life of 2 years. The purchase and installation of the bricks is reported to have cost $\$ 247,000$. The 1995 rebricking operation generated about 185 drums and over $40,000 \mathrm{~kg}$ of brick waste for disposal as LLW. The estimated disposal cost at $\$ 441 /$ drum is $\$ 81,400$.

It is not known how long the brick life will be extended by operating at a lower kiln temperature. Refractory specialists agree that a lower kiln temperature would be beneficial but have no basis for quantifying the benefit. A 1-year extension of the brick life would save $\$ 93,000 /$ year in installation, maintenance, purchase, and disposal costs and reduce the annual

brick disposal by $7000 \mathrm{~kg}$; however, the additional risk of downtime or kiln damage must be considered. Periodic monitoring of the brick condition might be required to justify extending the 2-year interval for brick replacement. 
Table 4.1 Unit costs used for TSCA Incinerator P2 options evaluation ${ }^{a}$

$$
\text { Item }
$$

Unit

Cost per unit

$(\$)$

Disposal of containerized mixed waste

Disposal of TSCA wastewater at CNF

Treatment of liquid waste at TSCA Incinerator

Disposal of refractory brick

Disposal of LLW metals

Disposal of LLW wood

Disposal of spent GAC.

Analysis of TSCA wastewater

Purchase of drums

Purchase of refractory brick

Purchase of new GAC

Purchase of process water

Purchase of diesel fuel

Purchase of wooden pallets

Purchase of plastic pallets

Purchase of metal pallets

Craft labor

Engineering labor 55-gal drum

441.00

gal

kg

0.18

$\mathrm{lb}$

$\mathrm{kg}$

kg

$\mathrm{kg}$

$\mathrm{kg}$

kg

$30 \mathrm{gal}$

55-gal drum

$\mathrm{kg}$

$\mathrm{kg}$

$\mathrm{kg}$

$1000 \mathrm{gal}$

$\mathrm{kg}$

each

each

each

hr

hr
0.048

5.00

11.00

4.85

6.00

6.00

6.00

1.00

30.75

1.708

0.62

2.20

2.43

0.25

10.00

90.00

100.00

51.00

70.00

a Costs for disposal and treatment of liquid waste, and purchase of process water, were obtained from Appendix B in the 'Guide to Estimating and Reporting Pollution Prevention Cost Benefits for the Oak Ridge Reservation, Paducah, and Portsmouth (LMES 1995c). 
Table 4.2 Cost information for TSCA Incinerator P2 options

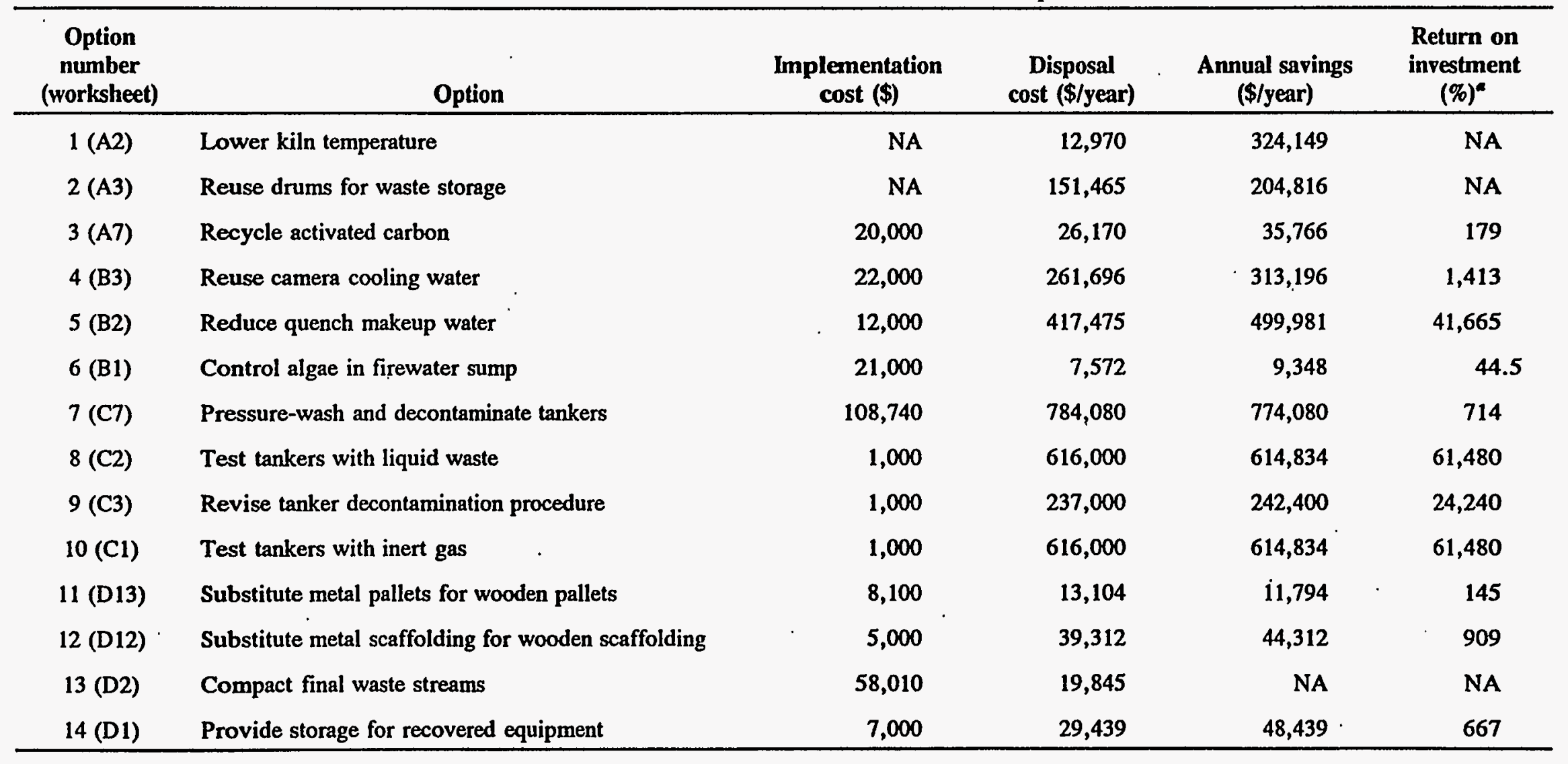

a Percent return on investment is, by definition, annual savings (times 100) divided by implementation cost. Three of these options do not have ROIs either because they have no implementation cost (i.e., Options 1 and 2) or because there is no net annual savings (Option 13). 
Also, a reduced kiln temperature of approximately $1500^{\circ} \mathrm{F}$ would reduce heat loss from the kiln and the mix chamber shell by up to 1 million Btu/hr, reducing the incinerator's supplemental fuel requirement by as much as 10 million Btu/hr. This reduced fuel use will result in an annual savings of $\sim \$ 230,000$. Because this option has a zero implementation cost, no ROI was calculated.

\subsubsection{Reuse Drums for Waste Storage (Option 2)}

Drums are required for both storage and disposal of a wide variety of the wastes generated at the site. Approximately 700 drums are required on an annual basis to store TSCA Incineratorgenerated wastes. Less than $5 \%$ of the 700 drums were used to store kiln ash. Assuming $18 \mathrm{~kg}$ per empty drum, this estimate results in $-12,600 \mathrm{~kg} /$ year of waste from drums storing on-site wastes. It is estimated that the waste (e.g., trash, carbon, PPE, etc.) stored in approximately $33 \%$ or 235 of the drums may be incinerated on-site; the other 465 are disposed of off-site. This option proposes the reuse of three categories of drums:

- drums that contain on-site waste targeted for incineration,

- drums that contained raw materials, and

- drums that have been decontaminated.

With the exception of GAC, the first category of drums uses liners that may prevent the contamination of the drum. It is proposed that recycled carbon be placed back into the drums from which it is removed. ${ }^{2}$ The second category of drums is regulated as empty and is not considered hazardous. Some of the drums in this category may be suitable for reuse without decontamination (i.e., drums that contained nonhazardous materials). The third category of drums represents the greatest potential P2 benefit. The reuse of decontaminated drums that contained waste is not currently prohibited by K-25 Site policy.

The reported solid waste feed incineration target for FY 1996 is $1,000,000 \mathrm{lb}(453,700 \mathrm{~kg})$, and for FY 1997 it is $2,000,000 \mathrm{lb}(907,400 \mathrm{~kg})$. It is expected that the solid feed will consist largely of soil-type waste feeds stored in drums. The treatment of solid wastes in FY 1996 may result in as many as $\mathbf{1 5 0 0}$ empty drums and require nearly as many new drums for the storage of ash. This estimate is based on an average bulk density of $90 \mathrm{lb} / \mathrm{ft}^{3}\left(40.8 \mathrm{~kg} / \mathrm{ft}^{3}\right)$ for soil and ash (from soil-type feeds).

The economics for reuse of drums are favorable. The total number of drums is estimated to be 1735 per year: 235 drums from the incineration of TSCA Incinerator-generated waste and 1500 drums from new solid waste feeds. The purchase cost per drum is $\$ 30.75$. Cost savings from new drum purchase will be $\$ 53,000$. The disposal cost per radioactively contaminated empty drum is $\$ 87$, and per year is estimated at $\$ 151,000$ for 1735 drums. The state currently requires drums storing TSCA waste to be triple rinsed before disposal. WMD is currently constructing a drum-washing facility to meet this requirement; this facility is scheduled to be operational in January 1996. Washed drums in good condition are expected to be reused (per WMD). The spent drum rinseate is expected to be sent to the TSCA Incinerator for incineration. The cost of drum washing is not currently known. Empty drums that contained RCRA wastes are not regulated (except for acutely toxic wastes). These drums could be reused if washed. It is proposed that a similar drum-washing operation for RCRA-empty drums be established as part

\footnotetext{
${ }^{2}$ The practice of reusing drums to containerize "treated" wastes is already being used on the ORR for fluorescent bulb recycling.
} 
of the drum-washing operation at WMD. Because this option has a zero implementation cost, no ROI was calculated.

\subsubsection{Recycle Activated Carbon (Option 3)}

The option to recycle GAC is proposed for both inventoried and generated spent carbon suitable for regeneration in the TSCA Incinerator; however, there are regulatory concerns related to recycling that will have to be addressed before implementation. The TSCA Incineratorgenerated carbon for 1994 is $5452 \mathrm{~kg}$, and additional carbon may be available for recycling from other ORR facilities.

The economics for recycling carbon are favorable. The cost of virgin carbon was estimated at $\$ 2.20 / \mathrm{kg}$, and the disposal cost is estimated at $\$ 6 / \mathrm{kg}$. The treatment, analytical, and storage costs for incineration of the carbon should be approximately the same regardless of whether the carbon is recycled or disposed. The initial program development costs to coordinate spent carbon storage and treatment are estimated at $\$ 20,000$. The program labor cost to track and test the absorption capacity of the regenerated carbon has not been estimated. These latter costs would be expected to be similar to or less than the labor costs required to arrange for disposal of the carbon. After recycling the carbon up to five times, the absorption capacity will not justify regeneration again, and the carbon will be disposed of as a waste. The estimated annual savings for the purchase and disposal of TSCA Incinerator GAC is $\$ 35,766$; the estimated ROI is $179 \%$.

\subsection{SUMP OPERATIONS}

Three options for sump operations were considered to reduce wastewater and GAC: (1) reuse of camera cooling water, (2) reduction of quench make-up water, and (3) algae control in the firewater sump.

Two additional options were evaluated but are not recommended; cost data for these options are provided for information purposes only. These options are: (1) use of a clarifier to control the TSS level of the wastewater discharged to the CNF and (2) routing the quench purge to the IWS sump.

\subsubsection{Reuse Camera Cooling Water (Option 4)}

The option to use the cooling water discharged from the SCC camera in the kiln camera has been proposed for consideration as a high return on investment (HiROI) P2 project. This option can be implemented immediately upon Site review and approval. It is estimated to cost $\$ 22,000$; reduce wastewater by $1.4 \mathrm{million}$ gal/year; and save $\sim \$ 313,000$ in analytical, disposal, and utility costs. The estimated ROI is $1413 \%$.

\subsubsection{Reduce Quench MakeUp Water (Option 5)}

The option for reducing the quench makeup water rate when not incinerating wastes is estimated to reduce the volume of wastewater by 4.0 million gal annually until the GCS Upgrade is implemented, saving $\sim \$ 500,000 /$ per year in analytical, disposal, and utility costs. This estimate was based on start-up and standby operations during $30 \%$ of the year and a normal quench makeup rate of $60 \mathrm{gpm}$ versus the reduced rate of $35 \mathrm{gpm}$. 
This option requires TSCA Incinerator Engineering review and approval to determine the maximum allowable burner firing rate that the 35 -gpm quench makeup water rate will safely quench. This firing rate could be determined during start-up or standby operation of the incinerator. The process logic interlock for burner firing rate at the low $(35 \mathrm{gpm})$ quench makeup rate could be temporarily bypassed at low burner firing rates while closely monitoring the quench outlet gas temperature. The burner firing rate could be manually increased gradually until a maximum safe (higher) quench gas outlet temperature (e.g., 190 ${ }^{\circ} \mathrm{F}$ ) was reached. This set of operating conditions (burner firing rate and quench outlet temperature) should be easily duplicated. Based on the experimentally determined maximum safe burner firing rate, the process interlock value would be reset. This option has an ROI of $41,665 \%$.

\subsubsection{Control Algae in Firewater Sump (Option 0)}

The option to control algae in the firewater sump proposes the use of an opaque tarpaulin cover over the sump to eliminate sunlight. The tarpaulin would be attached to a metal frame, with the centerline raised to provide drainage. The installed cost of the tarpaulin is estimated to be $\$ 21,000$. The life of the GAC that treats the firewater sump water is estimated to be increased by $25 \%$ by controlling the algae. The 1994 annual firewater-sump carbon use rate was estimated at $5,047 \mathrm{~kg}$. The annual estimated purchase and disposal cost savings were $\$ 10,348$, and the estimated ROI for this option is $44.5 \%$.

\subsubsection{Clarify Wastewater}

This option is considered for future operation after the GCS Upgrade project, which will result in a reduced wastewater discharge rate and potentially higher TSS loading. It is not currently known whether the TSS loading level will increase if the wastewater discharge flow is reduced by over $50 \%$.

The capital cost for a clarifier to remove TSS from the wastewater to meet the CNF limits is estimated to be $\sim \$ 50,000$. The total installed implementation cost is estimated to be $\$ 322,000$. No payback period was calculated for this option because it is not certain whether a clarifier will be required to meet the CNF WAC.

\subsubsection{Route Quench Purge to the IWS Sump}

This option was not recommended because of the extended period of time expected for regulatory approval (see the discussion in Sect. 3.2). The piping modification cost for this option was estimated to be $\$ 73,000$. If implemented before the GCS Upgrade, this option will reduce the annual wastewater discharge rate by 1.7 million gal, saving $-\$ 377,000 /$ year. The ROI for this option was not calculated.

\subsection{TANK AND TANKER OPERATIONS}

\subsubsection{Pressure-Washing and Decontaminate Tankers (Option 7)}

One option for reducing the generation of PCB-contaminated diesel fuel is to use a recirculating pressure wash system for the decontamination of tanker trucks. The system would consist of two 600-gal tanks and a pressure spray unit that would be placed inside the tanker. The implementation cost for this option is $\sim \$ 109,000$. Diesel fuel would be forced out of the nozzle 
at high pressure to clean the entire internal surface area inside of the tank. The fuel could be used for rinsing until the PCB concentrations exceed $50 \mathrm{ppm}$, at which time the fuel would be incinerated. Concentrations would be verified by field testing.

The advantages of this system include a significant reduction in the amount of diesel fuel required and more efficient decontamination of the tankers before hauling non-PCB waste. This option reduces waste generation by $108,000 \mathrm{~kg}$ and has an annual savings in disposal cost of $\$ 784,000$. The annual cost of implementing this option is estimated to be $\$ 10,000$. Installation of the system may also require secondary containment for the tanks and a fire suppression system.

The final advantage of this option may be the greater efficiency of the cleaning procedure. This has two possible benefits. Because final PCB concentrations may be lower than for the current procedure, there may be less risk to personnel conducting the annual internal inspection. For the same reason, if water continues to be used for hydrostatic leak/pressure testing, after tanker decontamination, the water may meet WAC for CNF. If this is achieved, the water may be discharged to the firewater sump for GAC or directly to CNF, in lieu of incineration. This option has an estimated ROI of $714 \%$.

\subsubsection{Test Tankers with Liquid Waste (Option 8)}

The DOT regulations for leak/pressure testing of tankers allows the use of liquid waste instead of water for the hydrostatic testing procedure. The implementation cost for this option is $\sim \$ 1000$, and the annual cost is estimated to be $\$ 1200$. The annual testing of the three TSCA tankers generates about $56,000 \mathrm{~kg}$ of water that is treated in the incinerator. The use of waste diesel fuel instead of potable water for hydrostatic testing would eliminate this waste stream, with an annual disposal cost savings of $\$ 616,000$. The estimated ROI is $61,480 \%$.

Although the elimination of this aqueous waste will reduce reportable generated quantities, the contaminated water currently is needed to cool the faceplate on the primary combustion chamber. At lower kiln temperatures, this cooling may not be required, thus making this option economically beneficial. Potential savings include reduced analytical cost for feed materials and reduced supplemental fuel requirements for combustion of aqueous wastes.

Another consideration for the implementation of this option is the possibility of spills or leaks during the testing procedure. When using wastes for the test, spills or leaks would be more serious than when using water. Currently, the access port on the tanker is left open while the tanker is being filled with water. During the proposed addition of liquid waste to the tanker, it may be possible to use a purge line to remove all air from the tanker while keeping the access port closed. This would reduce the probability of a reportable spill during testing operations.

\subsubsection{Recycle Activated Carbon (Option 3)}

The recycling and reuse of GAC from the tank farm vents would reduce the cost of virgin carbon and the disposal cost of spent carbon. GAC has been successfully regenerated in other rotary kiln incinerators. This option would require campaigning the carbon to be recycled as discussed in Sects. 3.1 and 4.1.3. Because there is an approximate 8\% loss of capacity with each regeneration cycle, the carbon would eventually be disposed of. 


\subsubsection{Revise Tanker Decontamination Procedure (Option 9)}

Another option is to standardize tanker washing and decontamination procedures at the incinerator tank farm. A new procedure could be written to accomplish this to reduce the amount of diesel fuel generated during inspection and washing operations. The implementation cost for this option is $\sim \$ 1000$. The estimated ROI is $24,240 \%$.

Tanker decontamination is performed by ET\&I personnel in conjunction with the annual leak test and by.TSCA Incinerator personnel before loading non-PCB wastes into a tanker previously used to haul PCB wastes. The use of the pressure sprayer (previously discussed) may eliminate the need for: tanker decontamination for personnel safety reasons by more efficiently removing PCB residues.

\subsubsection{Test Tankers with Inert Gas (Option 10)}

The use of a pneumatic test with an inert gas for leak/pressure testing of tankers is allowed by DOT regulations. This procedure requires no water and can be accomplished without generating any waste. The equipment is available commercially, or a vendor could perform the test at the TSCA Incinerator site. Currently, there are no cost savings for this option because of the need for this waste as cooling water for the incinerator. The implementation cost for this option is $\sim \$ 1000$, and the annual cost is estimated to be $\$ 1200$. Implementation of this option would eliminate $56,000 \mathrm{~kg}$ of contaminated water per year and save $\$ 616,000 /$ year in disposal costs. The estimated ROI is $61,480 \%$. Implementation of this option is contingent on its availability at the K-25 Site. Currently, the ET\&I Organization provides tanker-testing services, including the capability for pneumatic testing with either air or nitrogen. However, ET\&I personnel are concerned with the potential for tanker explosion resulting from this type of test. This concern will have to be addressed before this option is implemented.

\subsection{TSCA INCINERATOR SITE OPERATIONS}

The TSCA trash and solids waste stream, as defined in this PPOA, generated 71,203 kg of waste in 1994. The disposal cost for this waste is valued at $\$ 427,218$ in 1995 dollars. This study generated 14 proposed P2 options for TSCA trash and solids. Four recommendations were drawn from these options and were evaluated for implementation requirements and cost.

- Substitute metal or plastic pallets for wooden ones in TSCA Incinerator process areas.

- Substitute reusable metal scaffolding for single-use custom wooden scaffolding.

- Reduce the volume and mass of waste containers by compaction and drum reuse.

- Reduce the amount of scrap metal generated by enhancing recovery of usable materials.

\subsubsection{Substitute Metal Pallets for Wooden Pallets (Option 11)}

It is estimated that the TSCA Incinerator discarded $2184 \mathrm{~kg}$ of pallets in $1994 .^{3}$ Assuming a disposal cost of $\$ 6 / \mathrm{kg}$, the cost for disposal of pallets is $\$ 13,104$. Metal pallets are readily cleaned and provide long operational life. The change to plastic pallets allows decontamination and treatment by incineration.

\footnotetext{
${ }^{3}$ These numbers were estimated from the percentage of solid waste represented by this waste type in 1994.
} 
The cost involved in replacing wooden pallets with metal pallets as they are removed from service is $\sim \$ 8100$ in the first year. The cost for switching to plastic is $\sim \$ 7290$ in the first year. The ROI for either type of pallet is $\sim 145 \%$. However, because of their longer life and relative ease of decontamination, metal pallets are preferable. The TSCA Incinerator Division feels that a transition from wooden to metal pallets is not appropriate at this time. Concerns are as follows:

- The replacement of wooden pallets with those of another material (either plastic or metal) will probably need to be a K-25 Site-wide initiative to take full advantage of the potential economy of scale.

- This PPOA defines metal pallets in a limited degree of detail. Further study is needed to evaluate the need, availability, and cost of pallets with properties such as non-sparking and skid-proof. Questions have also been raised as to the need for electrical grounding of this type of pallet.

\subsubsection{Substitute Metal Scaffolding for Wooden Scaffolding (Option 12)}

In CY 1994, the TSCA Incinerator discarded $6552 \mathrm{~kg}$ of lumber from scaffolding constructed in the process areas. ${ }^{3}$ Because of its porosity, this wood cannot be decontaminated. Wood cannot presently be treated or incinerated, so the only alternative is storage and disposal. Assuming a disposal cost of $\$ 6 / \mathrm{kg}$, the facility spent $\$ 39,312$ in 1994 .

This option addresses both the purchase and rental of metal scaffolding instead of wood. Metal scaffolding can be reused in a variety of applications, can be decontaminated to allow storage in clean areas, and can meet all safety standards. As with metal pallets, metal scaffolding must also be skid-proof. This type of scaffolding is used throughout the nuclear industry and can be conveniently stored. The annual savings for metal scaffolding purchase and rental are, respectively, $\$ 44,312$ and $\$ 28,312$. Therefore, purchase of scaffolding is the recommended option. The estimated ROI for this option is $909 \%$.

\subsubsection{Compact Final Waste Streams (Option 13)}

Compaction reduces the number of metal containers used for waste disposal and will reduce the overall mass and volume of waste for disposal. A compaction efficiency of ten to one ${ }^{4}$ results in a mass reduction of $28 \%$ (because of eliminating containers) and a reduction in disposal cost of $90 \%$. Reducing the number of drum-handling and decontamination episodes also provides benefits of reducing opportunities of injury and reduces the amount of disposed cleaning supplies. Emission of volatile organics can be addressed by equipping the compactor with a GAC filter. Because there are no free liquids in the trash and solids waste stream, secondary containment is not needed under the compactor.

Equipment and site preparation costs are calculated to be around $\$ 58,000$. This price includes installing the compactor, upgrading the electrical system, and installing an air filtration unit on the compactor. For the purposes of this option, it was estimated that 50 drums/year are candidates for compaction at a 10:1 compaction ratio (e.g., laboratory glassware). The disposal cost savings are expected to be $\sim \$ 20,000$. The annual operating cost for this option is $\$ 22,000$. Because of the negative annual operating cost, an ROI was not calculated.

\footnotetext{
${ }^{4}$ Based on vendor feedback for compaction of glassware.
} 


\subsubsection{Provide Storage for Recovered Equipment (Option 14)}

It is estimated that the scrap metal disposal costs could be reduced by $\$ 29,439$ annually if $33 \%$ of the scrap metal generated was from reusable equipment. ${ }^{5}$ Savings from the reuse of contaminated equipment (compared to the purchase of new equipment) was assumed to be $\$ 20,000 /$ year. From the estimated reduced disposal costs, six PCB-capacitor shipment boxes ( $\$ 1000$ each) could be purchased each year for equipment storage. Following this initial investment, annual savings will be $\$ 48,439$. The estimated ROI is $667 \%$. 


\section{IMPLEMENTATION PLAN AND FUNDING}

Of the 14 options evaluated further, 7 are recommended for implementation (Table 5.1). HiROI proposals were not written for Options 1,2 , and 5 because they require no funding, but HiROI proposals have been written for the other four options. These four HiROI proposals were ranked (see Table 5.2) following the "Criteria for Selecting High Investment Value Pollution Prevention Projects" (LMES 1995d). The funding for the recommended options is available from two sources-ESWMO's HiVal program and DOE Oak Ridge Operations. The implementation schedule and funding for the recommended options are based on evaluation from TSCA Incinerator personnel.

Table 5.1 TSCA Incinerator $\mathbf{P} 2$ recommended option implementation plan and funding

\begin{tabular}{lccccc}
\hline \multicolumn{1}{c}{ Option name } & $\begin{array}{c}\text { ROI proposal } \\
\text { prepared } \\
\text { (yes/no) }\end{array}$ & $\begin{array}{c}\text { Implementation } \\
\text { schedule (years) }\end{array}$ & $\begin{array}{c}\text { Implementation } \\
\text { status }\end{array}$ & $\begin{array}{c}\text { Funding } \\
\text { source/status }\end{array}$ \\
\hline $\begin{array}{l}\text { Lower kiln temperature } \\
\text { (Option 1) }\end{array}$ & No & 3 & planning & $\begin{array}{c}\text { DOE-ORO/ } \\
\text { unfunded }\end{array}$ \\
$\begin{array}{l}\text { Reuse drums for waste } \\
\text { storage (Option 2) }\end{array}$ & No & 0.5 & planning & $\begin{array}{c}\text { DOE-ORO/ } \\
\text { unfunded }\end{array}$ \\
$\begin{array}{l}\text { Reuse camera cooling } \\
\text { water (Option 4) }\end{array}$ & Yes & 0.5 & procurement & HiVal/funded \\
$\begin{array}{l}\text { Reduce quench makeup } \\
\text { water (Option 5) }\end{array}$ & No & 0.5 & planning & $\begin{array}{c}\text { DOE-ORO/ } \\
\text { unfunded }\end{array}$ \\
$\begin{array}{l}\text { Test tankers with inert } \\
\text { gas } \\
\text { (Option 10) }\end{array}$ & Yes & 0.5 & planning & $\begin{array}{c}\text { DOE-ORO/ } \\
\text { unfunded }\end{array}$ \\
$\begin{array}{l}\text { Substitute metal } \\
\text { scaffolding for wooden } \\
\text { scaffolding (Option 12) }\end{array}$ & Yes & 0.5 & procurement & HiVal/funded \\
$\begin{array}{l}\text { Provide storage for } \\
\text { recovered equipment } \\
\text { (Option 14) }\end{array}$ & Yes & 0.5 & procurement & HiValffunded \\
\hline
\end{tabular}

a This option to be implemented as part of the TSCA Incinerator permitting effort scheduled to start in FY96 and to be completed in FY99.

'Option dependent on satisfactory resolution of ET\&I's safety concerns. 
Table 5.2. HiROI proposal ranking

\begin{tabular}{|c|c|c|c|c|c|c|c|c|c|}
\hline \multicolumn{2}{|l|}{$\begin{array}{l}\text { Option number } \\
\text { Option description }\end{array}$} & \multicolumn{2}{|c|}{$\begin{array}{c}4 \\
\text { Camera water }\end{array}$} & \multicolumn{2}{|c|}{$\begin{array}{c}10 \\
\text { Pneumatic test }\end{array}$} & \multicolumn{2}{|c|}{$\begin{array}{c}12 \\
\text { Metal scaffold }\end{array}$} & \multicolumn{2}{|c|}{$\begin{array}{c}14 \\
\text { Equipment storage }\end{array}$} \\
\hline HiROI Factor & Weight (W) & Scale(S) & $\mathbf{W} * \mathbf{S}$ & Scale(S) & $\mathbf{W} * \mathbf{S}$ & Scale(S) & $\mathbf{W} \mathbf{S}$ & Scale(S) & $\mathbf{W} \mathbf{S}$ \\
\hline Return on Investment & 25 & 10 & 250 & 10 & 250 & 10 & 250 & 10 & 250 \\
\hline Waste Quantity & 25 & 3 & 75 & 10 & 250 & 10 & $250^{\circ}$ & 3 & 75 \\
\hline Waste Hazard & 25 & 10 & 250 & 10 & 250 & 3 & 75 & 3 & 75 \\
\hline Technical Risk & 10 & 10 & 100 & 10 & 100 & 10 & 100 & 10 & 100 \\
\hline Environmental compliance/liability & 5 & 5 & 25 & 5 & 25 & 5 & 25 & 5 & 25 \\
\hline Waste treatment/disposal liability & 5 & 1 & 5 & 1 & 5 & 1 & 5 & 1 & 5 \\
\hline Position on EPA hierarchy & 5 & 8 & 40 & 10 & 50 & 10 & 50 & 8 & 40 \\
\hline TOTAL & & & 745 & & 930 & & 755 & & 570 \\
\hline RANK & & & 3 & & 1 & & 2 & & 4 \\
\hline
\end{tabular}


Preliminary Implementation Schedule for Option 1,

Lower Kiln Temperature

\begin{tabular}{|c|c|c|c|c|c|c|c|c|}
\hline Task Name & Dumtho & annt & 94 & \begin{tabular}{|c|}
1995 \\
\end{tabular} & 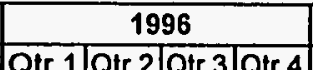 & 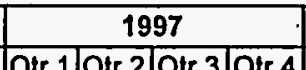 & \begin{tabular}{|c|}
1998 \\
01010 (1) \\
\end{tabular} & \begin{tabular}{|l|l|} 
& 1 \\
Qtr 1 & Qtr 2 \\
\end{tabular} \\
\hline Permitting & $325 d$ & Mon 6/3/96 & & & & & & \\
\hline Develop Permit Applications & 180ed & Mon 6/3/96 & & & & & & \\
\hline Submit Permit to TDEC \& EPA & 58ed & Thu 1/2/97 & & & & & & \\
\hline Permit Reviewed By EPA & 182ed & Mon 3/3/97 & & & & & & \\
\hline Enhanced Feasibility Study & $152 d$ & Mon 8/1/94 & & & & & . & \\
\hline Conceptual Design Report & 89d & Wed 3/1/95 & & & & & & \\
\hline Enhanced CDR & 132d & Sun 10/1/95 & & & & & & \\
\hline Validate Construction & Od & Sun $3 / 31 / 96$ & & & & & & \\
\hline Startup & 22d & Thu 10/1/98 & & & & & & \\
\hline Trial Burn / Air Test & 66d & Mon 11/2/98 & & & & & & \\
\hline Resume Normal Operations & Od & Mon 2/1/99 & & & & & & \\
\hline
\end{tabular}

Fig. 5.1. Implementation schedule for Option 1. 


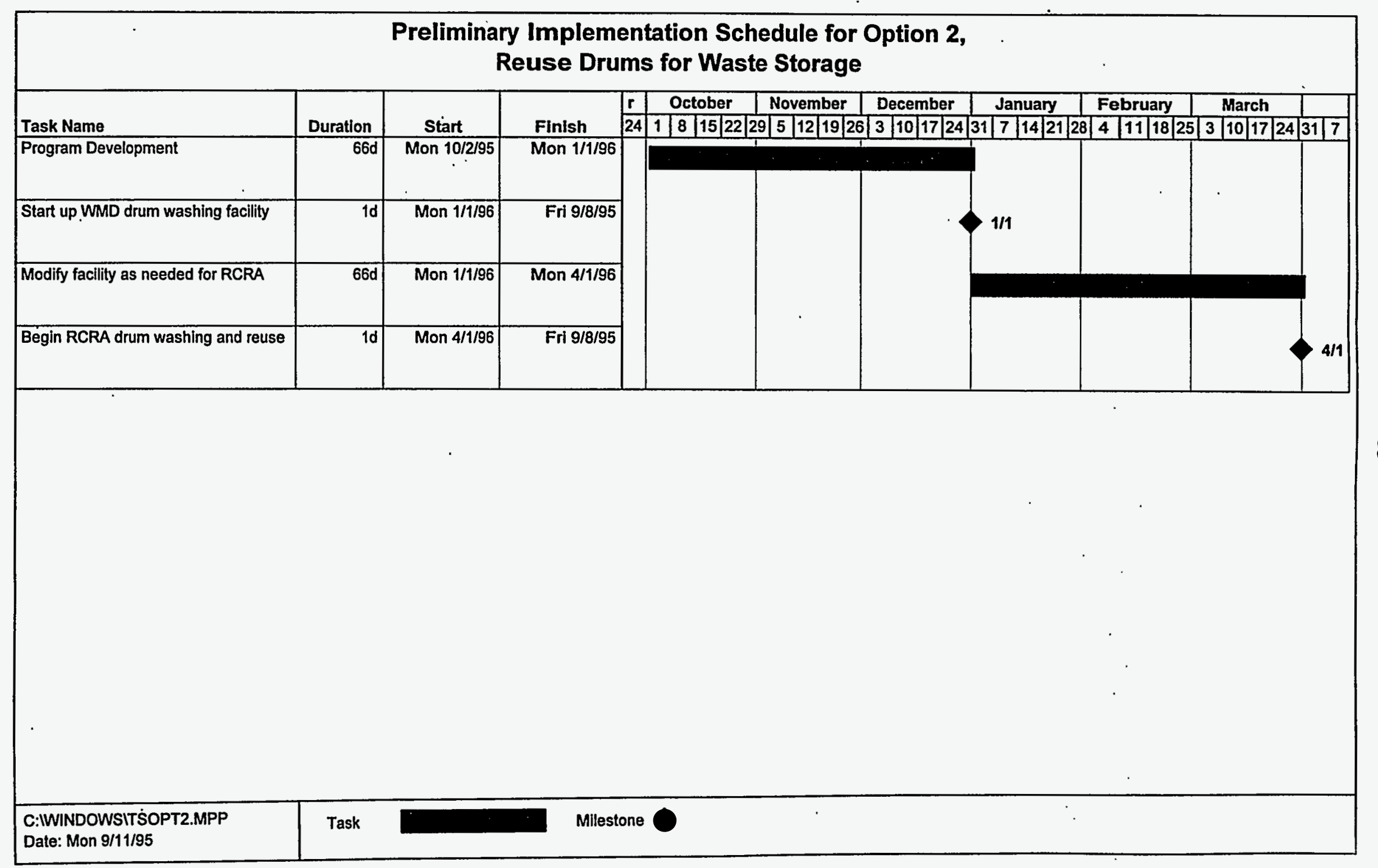

Fig. 5.2. Implementation schedule for Option 2. 


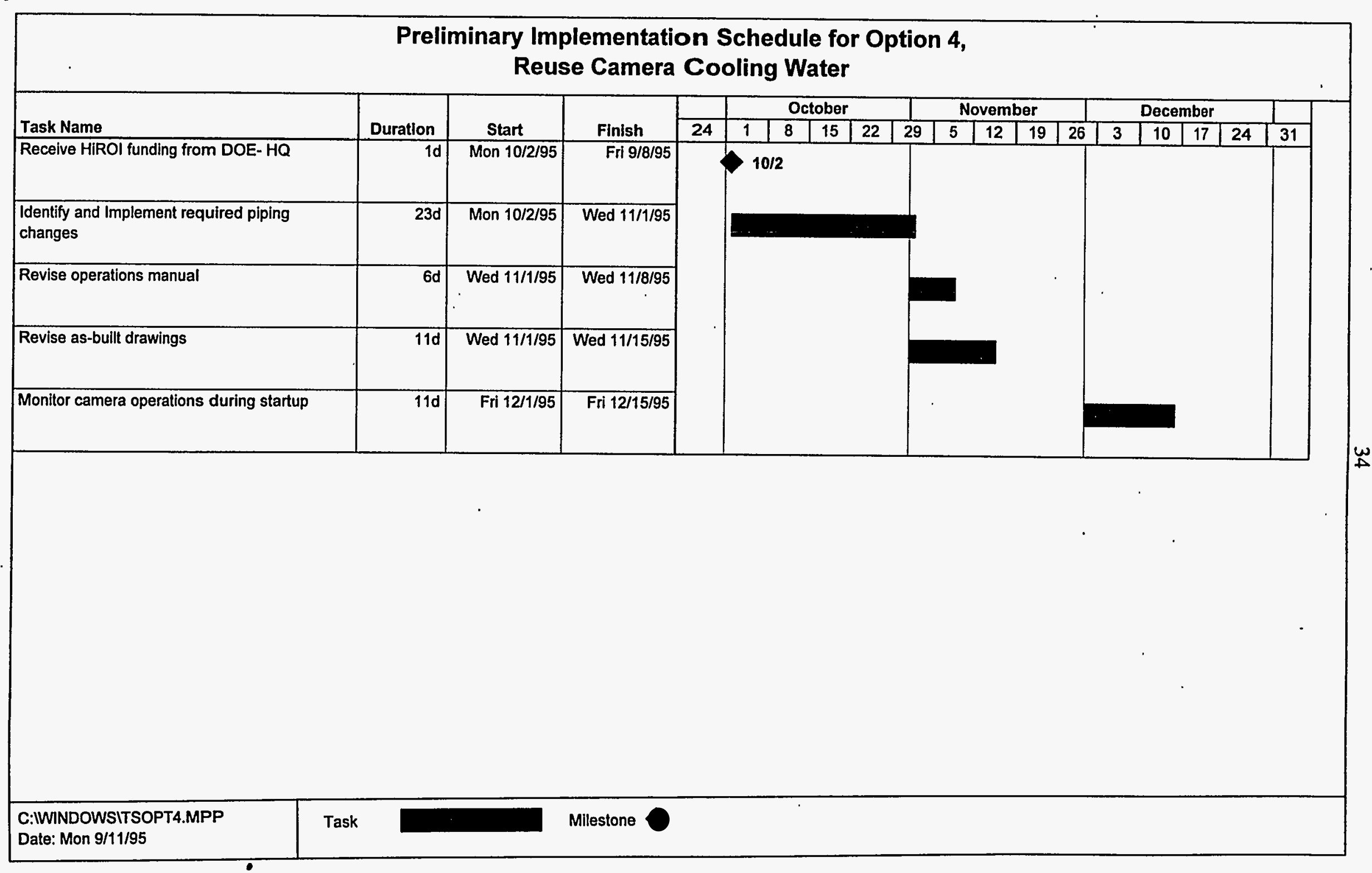

Fig. 5.3. Implementation schedule for Option 4. 
Preliminary Implementation Schedule for Option 5, Reduce Quench Makeup Water

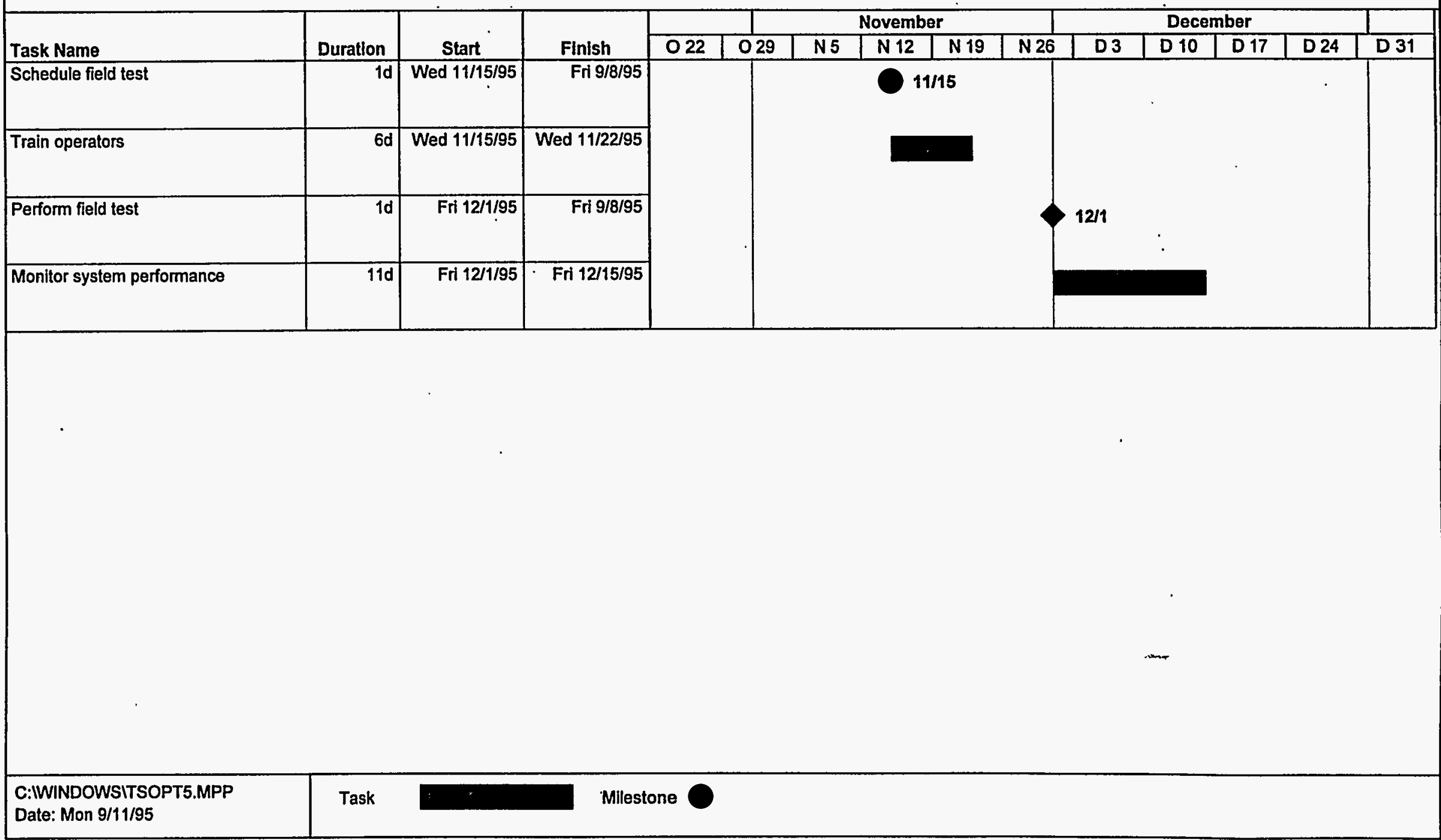

Fig. 5.4. Implementation schedule for Option 5. 


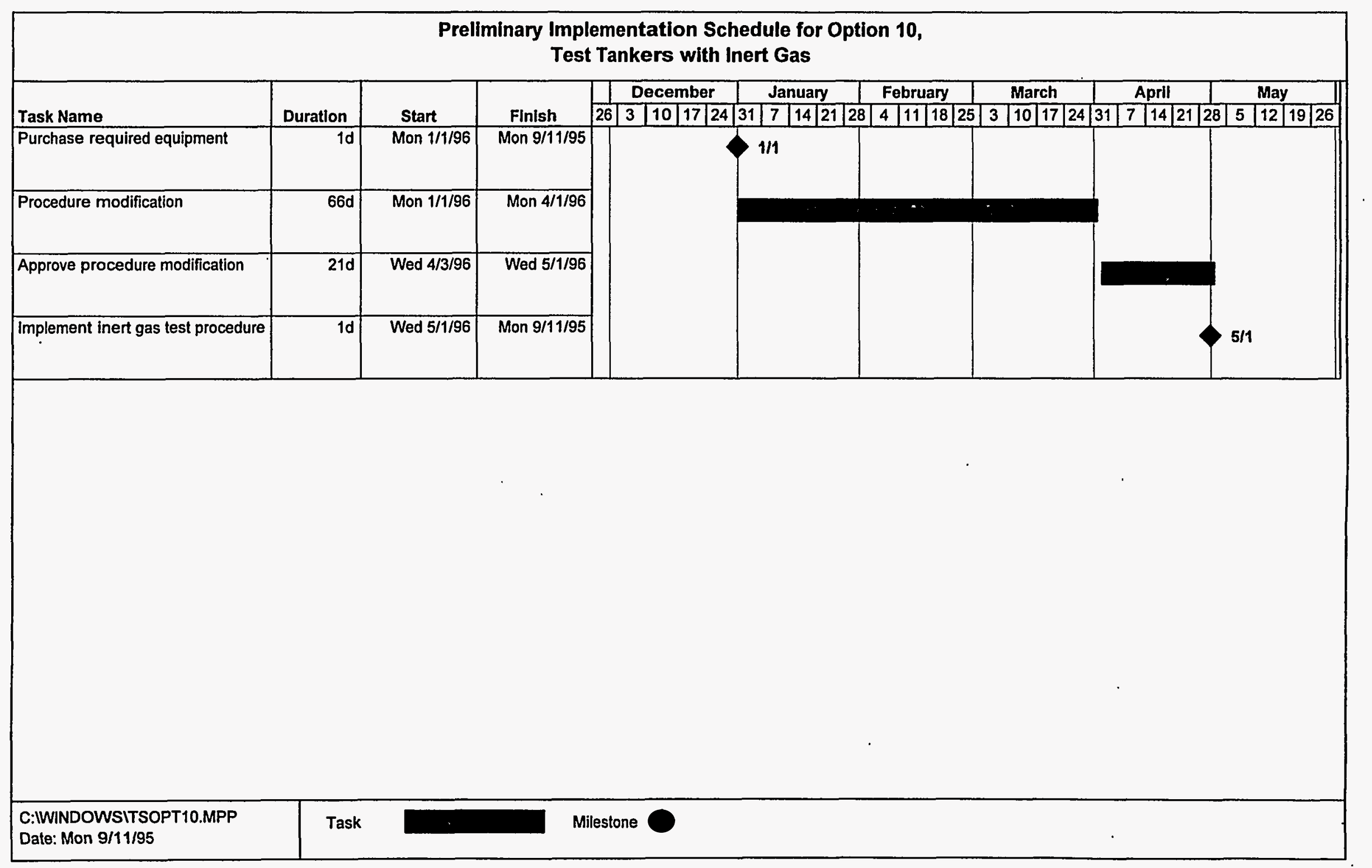

Fig. 5.5. Implementation schedule for Option 10. 


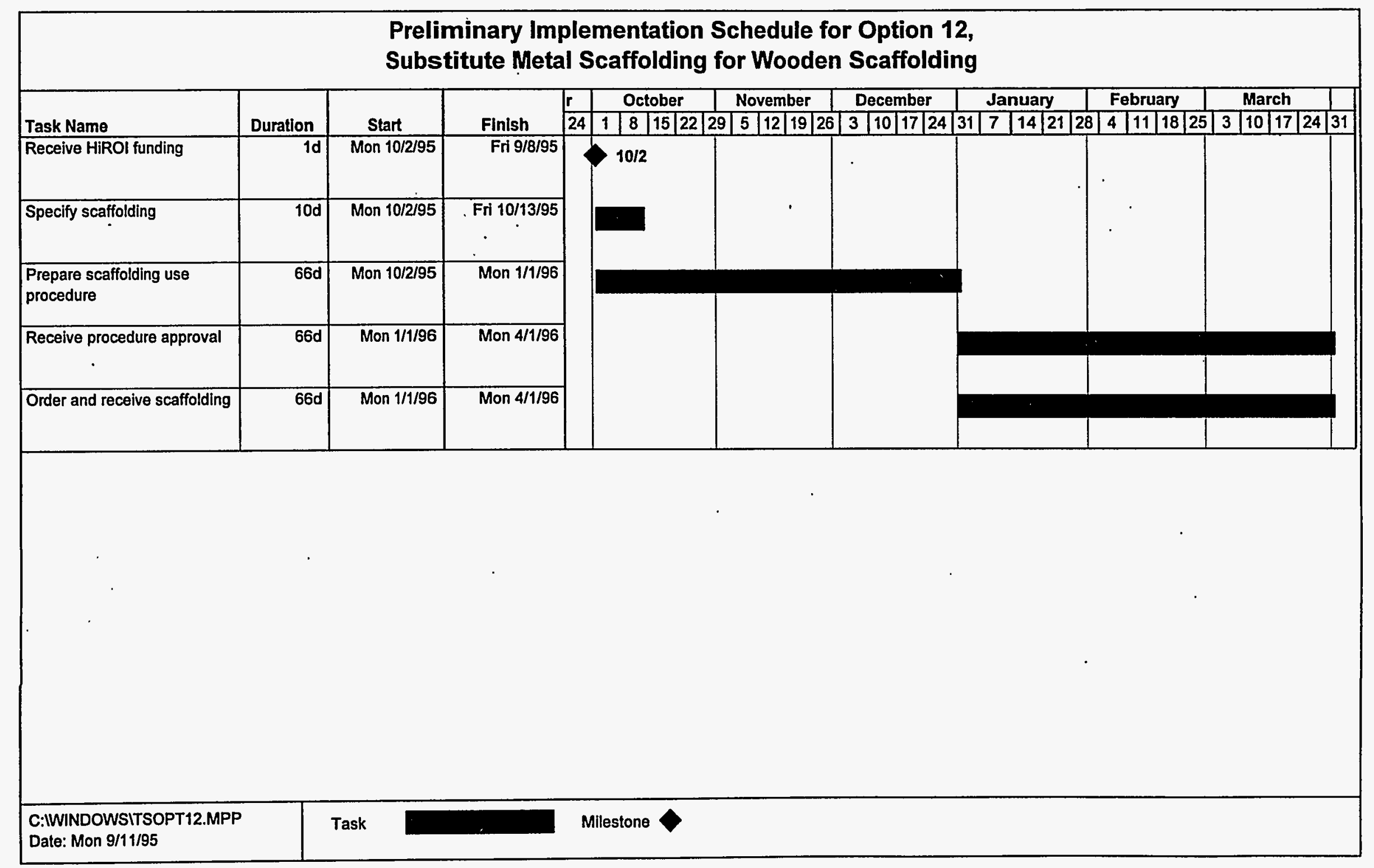

Fig. 5.6. Implementation schedule for Option 12. 


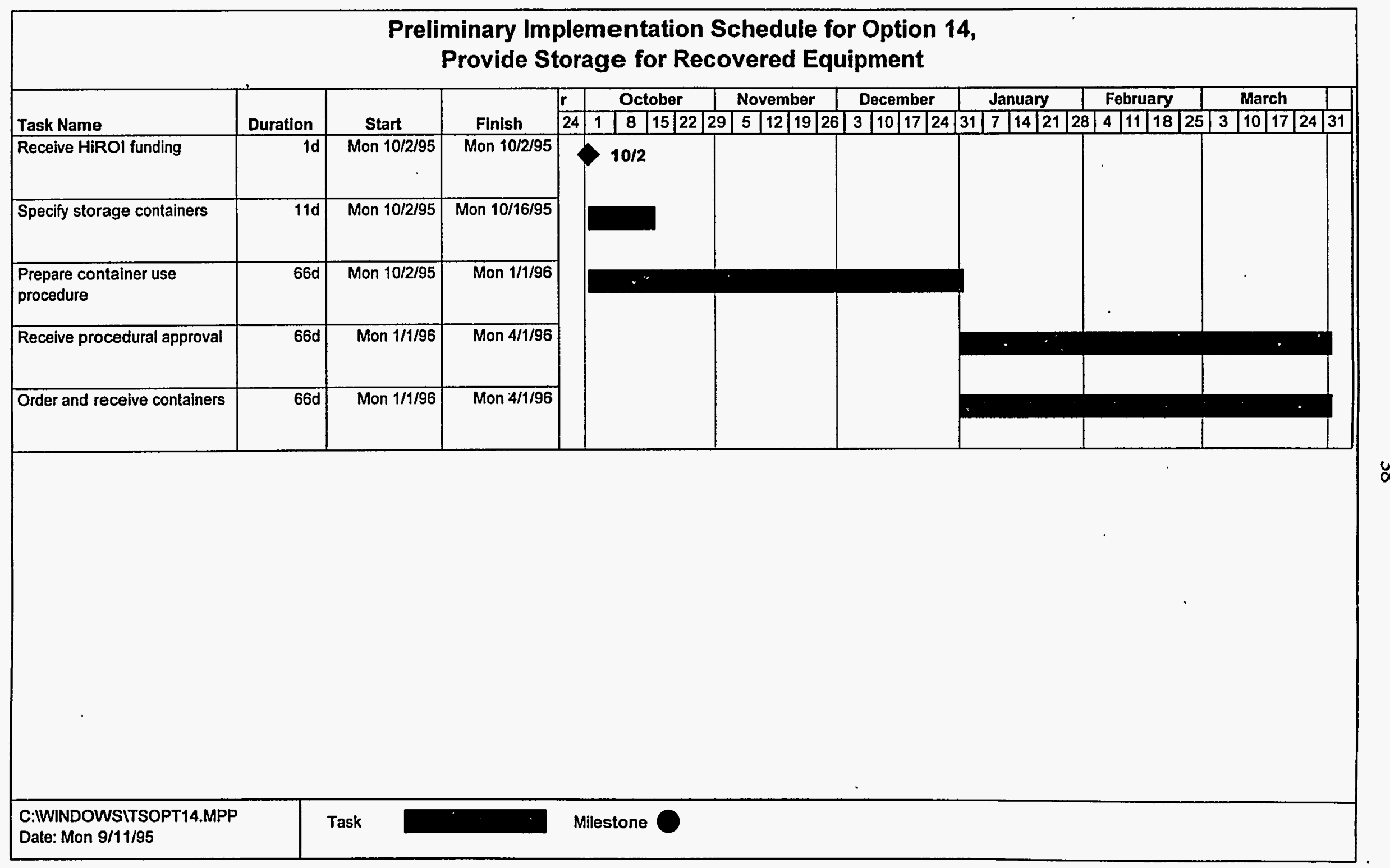

Fig. 5.7. Implementation schedule for Option 14. 


\section{CONCLUSIONS}

Fourteen options were evaluated to reduce wastes generated at the TSCA Incinerator; seven of these options were recommended for implementation and are summarized in Table 6.1. Upon implementation of these seven, an annual waste reduction of $14,254,688 \mathrm{~kg}$ will be realized, with an annual savings of $\$ 2,049,727$. Of these, three options were evaluated for both kiln and sump operations, and four were evaluated for both sump and TSCA.Incinerator site operations. These options are discussed for each operation below.

\subsection{KILN OPERATIONS}

The three options evaluated for kiln operations are to lower the kiln temperature, reuse drums, and recycle GAC. The first two of these options are recommended.

- Lowering the kiln temperature (as part of the GCS Upgrade Line Item) is expected to extend the kiln brick refractory life, significantly reduce the natural gas fuel requirements, and improve process operations by reducing the potential for undesirable slag formation in the kiln when feeding soils. This option may provide the highest cost savings of all the P2 recommendations and has a zero cost to implement.

- When solid wastes are incinerated later in CY 1995, empty drums will result in a sizable waste stream unless the drums are reused. The potential for using the WMD drum-washing facility to wash RCRA-contaminated drums needs to be evaluated. The costs for drumwashing operations were not available.

- A program to recycle GAC may be practical, reduces disposal costs and waste quantities, and can be implemented at almost no added cost. The technical feasibility of recycling GAC generated by the TSCA Incinerator requires field testing to determine if the solid fines imbedded in the GAC pores prevent successful regeneration of the GAC.

\subsection{SUMP OPERATIONS}

The three options evaluated for sump operations are to reuse the camera cooling water, reduce the quench make-up water, and control algae in the firewater sump. The first two of these options are recommended and can be implemented very quickly. The camera cooling water option has been proposed as a HiROI project.

- Reusing the camera cooling waster is a very straightforward, practical, and simple P2 recommendation that reduces both wastewater and analytical costs.

- Reducing the quench make-up water is one of the lowest cost and highest return P2 recommendations that can be implemented quickly; it will significantly reduce wastewater and provide considerable cost savings until the GCS Upgrade is implemented.

- Covering the firewater sump to control algae is a simple, long-term, low-cost recommendation for reducing. waste by prolonging the life of GAC. Further evaluation is required to 
determine the extent that algae growth reduces the lifetime of the GAC before this option can be recommended. Non-algal fines also contribute to the premature pluggage of the GAC.

\subsection{TANK/TANKER OPERATIONS}

The four options evaluated for tank/tanker operations are to pressure wash and decontaminate tankers, revise the tanker decontamination procedure, pressure test the tankers with waste, and pressure test the tankers with inert gas. Of these, only the last option is recommended.

- Pressure washing tankers and revising the decontamination procedure would reduce the reported waste. However, the diesel fuel used for these procedures is required for waste blending operations. Therefore, this option is not recommended at this time.

- Pressure testing the tanks and tankers with waste or inert gas will eliminate the aqueous waste generated by this activity. The use of inert gas to perform the test at low pressure is the preferred method because leaks detected from using a waste liquid would constitute a reportable spill. However, concerns have been expressed about explosion hazards during pneumatic testing; these concerns will have to be addressed.

\subsection{TSCA INCINERATOR SITE OPERATIONS}

The four recommended options for TSCA Incinerator Site operations are to substitute metal pallets for wooden pallets, substitute metal scaffolding for wooden scaffolding, compact the wastes sent off-site, and store and reuse contaminated equipment. The second and last options are recommended for implementation.

- Substituting metal pallets for wooden pallets is a low-cost, long-term recommendation for reducing waste. However, K-25 Site-wide use would be required for feasible implementation of this option because of the widespread transportation and use of pallets. Also, spark- and skid-resistant materials would be required in storage areas that stored combustible materials. Electrical grounding of the pallets is also a concern.

- Substituting metal scaffolding for wooden scaffolding is recommended as a low-cost, longterm option for reducing waste.

- Compacting the laboratory glassware waste sent off-site for disposal reduces container waste generation and reduces disposal costs. However, the benefits of this option are offset by sampling requirements required by the "debris rule" [i.e., 40 CFR 268.2 (g) and 268.45], and also by the regulatory requirement to control fugitive emissions during compaction operations.

- The storage and reuse of contaminated equipment is recommended as a low-cost option to reduce metal scrap waste and potentially save significantly on the replacement cost of new equipment. 
Table 6.1 Summary of TSCA Incinerator recommended P2 options

\begin{tabular}{|c|c|c|c|c|}
\hline Option name & $\begin{array}{c}\text { Waste reduction } \\
\text { (kg/year) }\end{array}$ & $\begin{array}{l}\text { Implementatio } \\
\text { n cost (\$) }\end{array}$ & $\begin{array}{c}\text { Annual } \\
\text { savings (\$) }\end{array}$ & ROI (\%) \\
\hline Lower kiln temperature (Option 1) & 7,000 & 0 & 324,149 & $\mathrm{NA}^{a}$ \\
\hline $\begin{array}{l}\text { Reuse drums for waste storage } \\
\text { (Option 2) }\end{array}$ & 31,230 & 0 & 204,816 & $\mathrm{NA}^{a}$ \\
\hline $\begin{array}{l}\text { Reuse camera cooling water } \\
\text { (Option 4) }\end{array}$ & $5,452,000$ & 22,000 & 313,196 & 1,413 \\
\hline $\begin{array}{l}\text { Reduce quénch makeup water } \\
\text { (Option 5) }\end{array}$ & $8,697,000$ & 12,000 & 499,981 & 41,665 \\
\hline $\begin{array}{l}\text { Test tankers with inert gas } \\
\text { (Option 10) }\end{array}$ & 56,000 & 1,000 & 614,834 & 61,480 \\
\hline $\begin{array}{l}\text { Substitute metal scaffolding for } \\
\text { wooden scaffolding (Option 12) }\end{array}$ & 6,552 & 5,000 & 44,312 & 909 \\
\hline $\begin{array}{l}\text { Provide storage for recovered } \\
\text { equipment (Option 14) }\end{array}$ & 4,906 & 7,000 & 48,439 & 667 \\
\hline
\end{tabular}

a Implementation costs for these options is zero; therefore, an ROI cannot be calculated. 



\section{REFERENCES}

U.S. Department of Energy (DOE). 1993. Model Pollution Prevention Opportunity Assessment Guidance, December.

DOE. 1995. High Return on Investment Pollution Prevention Projects Round 2 Program Guidance, p. 11, May.

Lockheed Martin Energy Systems, Inc. (LMES). 1995a. Level III Pollution Prevention Opportunity Assessment for the K-25 TSCA Incinerator Wastewater Stream, K/WM-83, February.

LMES. 1995b. Preparation of Level I and Prioritization of Level II and Level III Pollution Prevention Opportunity Assessments at the Oak Ridge K-25 Site, Oak Ridge, Tennessee, Phase II Study, K/WM-85, February.

LMES. 1995c. Guide to Estimating and Reporting Pollution Prevention Cost Benefits for the Oak Ridge Reservation, Paducah, and Portsmouth, Appendix B, in preparation, July.

LMES. 1995d. Memorandum from ESWMO's James F. Betschart to PAI Corporation's Steve Kirslis, "Criteria for Screening and Selecting High Investment Value Pollution Prevention Projects," August 24. 
Appendix A

\section{PPOA Worksheets}

for Kiln Operations 

A-3

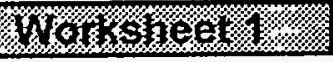

Level III
Revision No.: 0

Revision Date:9/08/95

\section{Pollution Prevention Opportunity Assessment PPOA Team}

PPOA Title: TSCA Incinerator

PPOA ID Code: TSCA Kiin Operations

\begin{tabular}{lll} 
Name & Job Classification & Phone \\
\hline \hline James T. Nelson & Sr. Environmental Engineer & $615 / 483-0666$ \\
Wiliam Nicholas & Sr. Environmental Engineer & $615 / 483-0666$ \\
Steven J. Kirslis & Environmental Engineer & $615 / 483-0666$ \\
Marshall A. Eaves & Project Engineer & $615 / 576-3974$ \\
James E. Dunn, Jr. & $\begin{array}{l}\text { Engineering and Analysis Department } \\
\text { Manager }\end{array}$ & $615 / 241-5751$ \\
W. Gerald Melton & $\begin{array}{l}\text { Manager-Waste and Residuals Management } \\
\text { Program }\end{array}$ & $615 / 241-2100$ \\
Fidel Perez & TSCA Incinerator Division Director & $615 / 576-5257$
\end{tabular}




\title{
Pollution Prevention Opportunity Assessment
}

\section{Process Description}

\author{
PPOA Title: TSCA Incinerator
}

PPOA ID Code: TSCA Kiln Operations

Process Location: TSCA Incinerator - K-25 Site

Process Description: The rotary kiln is the primary combustion chamber of the TSCA incinerator. The kiln is lined with refractory brick that is periodically replaced. Feed materials will include liquids, solids, sludges to be incinerated, and granular activated carbon to be recycled. Ash is collected in a sump sealed with process water. Gas and fines pass through the secondary combustion chamber before being removed in the gas cleaning system.

\section{Description of Major Product(s) of Process:}

ash, bricks, gases, and fines 


\section{Pollution Prevention Opportunity Assessment \\ Process Flow Diagram}

PPOA Title or PPOA ID Code(s): TSCA Kiln Operations

Inputs:

Fiberboard Boxes

Brick

New Drums

GAC

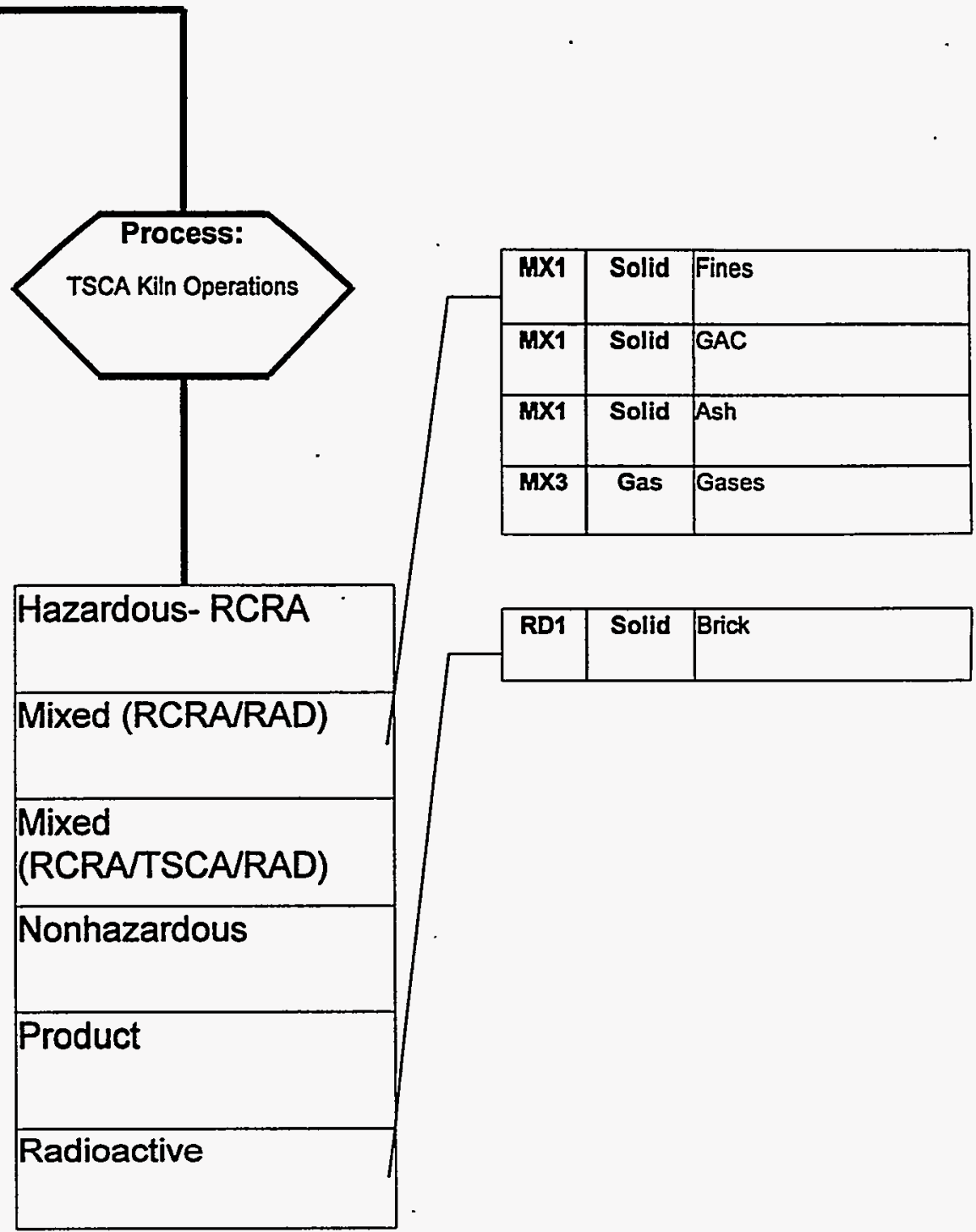




\section{Pollution Prevention Opportunity Assessment}

Material Balance Summary

PPOA Title or PPOA ID Code(s): TSCA Kiln Operations

Output Quantity Units: KG

\begin{tabular}{|c|c|c|c|c|}
\hline \multirow{2}{*}{\begin{tabular}{|l} 
Material Description \\
\end{tabular}} & \multirow[t]{2}{*}{$\begin{array}{l}\text { Total } \\
\text { Output }\end{array}$} & $\begin{array}{l}\text { Stream } \\
\text { ID Code }\end{array}$ & $\begin{array}{l}\text { Stream } \\
\text { m Code }\end{array}$ & $\begin{array}{l}\text { Stream } \\
\text { ID Code }\end{array}$ \\
\hline & & MX1 & MX3 & RD1 \\
\hline Gases & 0 & 0 & 0 & 0 \\
\hline GAC & 0 & 0 & 0 & 0 \\
\hline Fines & 0 & 0 & $\overline{0}$ & $\overline{0}$ \\
\hline Brick & 22,000 & $\overline{0}$ & $\overline{0}$ & $\overline{22,000}$ \\
\hline Ash & 1,165 & 1,165 & 0 & 0 \\
\hline Totals/Subtotals & 23,165 & 1,165 & 0 & 22,000 \\
\hline
\end{tabular}




\section{Pollution Prevention Opportunity Assessment}

\section{Input Material and Output Disposal Cost}

PPOA Title or PPOA ID Code: TSCA Kiln Operations

Input Material Cost:

\begin{tabular}{|c|c|c|c|}
\hline Material & Quantity (kg) & Cost Per Unit & Annual Cost \\
\hline$\overline{G A C}$ & 0.00 & 0 & $\$ 0.00$ \\
\hline Fiberboard Boxes & 0.00 & 0 & $\$ 0.00$ \\
\hline$\overline{\text { Brick }}$ & $22,000.00$ & 0.45 & $\$ 9,900.00$ \\
\hline New Drums & $1,062.00$ & 1.71 & $\$ 1,816.02$ \\
\hline Total/Subtotal & $23,062.00$ & & $\$ 11,716.02$ \\
\hline
\end{tabular}

Waste Disposal Cost:

\begin{tabular}{|c|c|c|c|c|}
\hline Material/Waste Stream & $\begin{array}{c}\text { Stream } \\
\text { Code }\end{array}$ & Qty (kg) & Cost Per Unit & Annual Cost \\
\hline Fines & $M \times 1$ & 0 & 0) & $\$ 0.00$ \\
\hline$\overline{G A C}$ & $\mathrm{MX1}$ & 0 & 0 & $\$ 0.00$ \\
\hline Gases & $\mathrm{MX3}$ & 0 & 이 & $\$ 0.00$ \\
\hline Ash & MX1 & 1,165 & 1.54 & $\$ 1,794.10$ \\
\hline Brick & RD1 & 22,000 & 1.89 & $\$ 41,580.00$ \\
\hline Total/Subtotal & & 23,165 & & $\$ 43,374.10$ \\
\hline
\end{tabular}




\section{Pollution Prevention Opportunity Assessment}

\section{Option Generation}

PPOA Title or PPOA ID Code: TSCA Kiln Operations

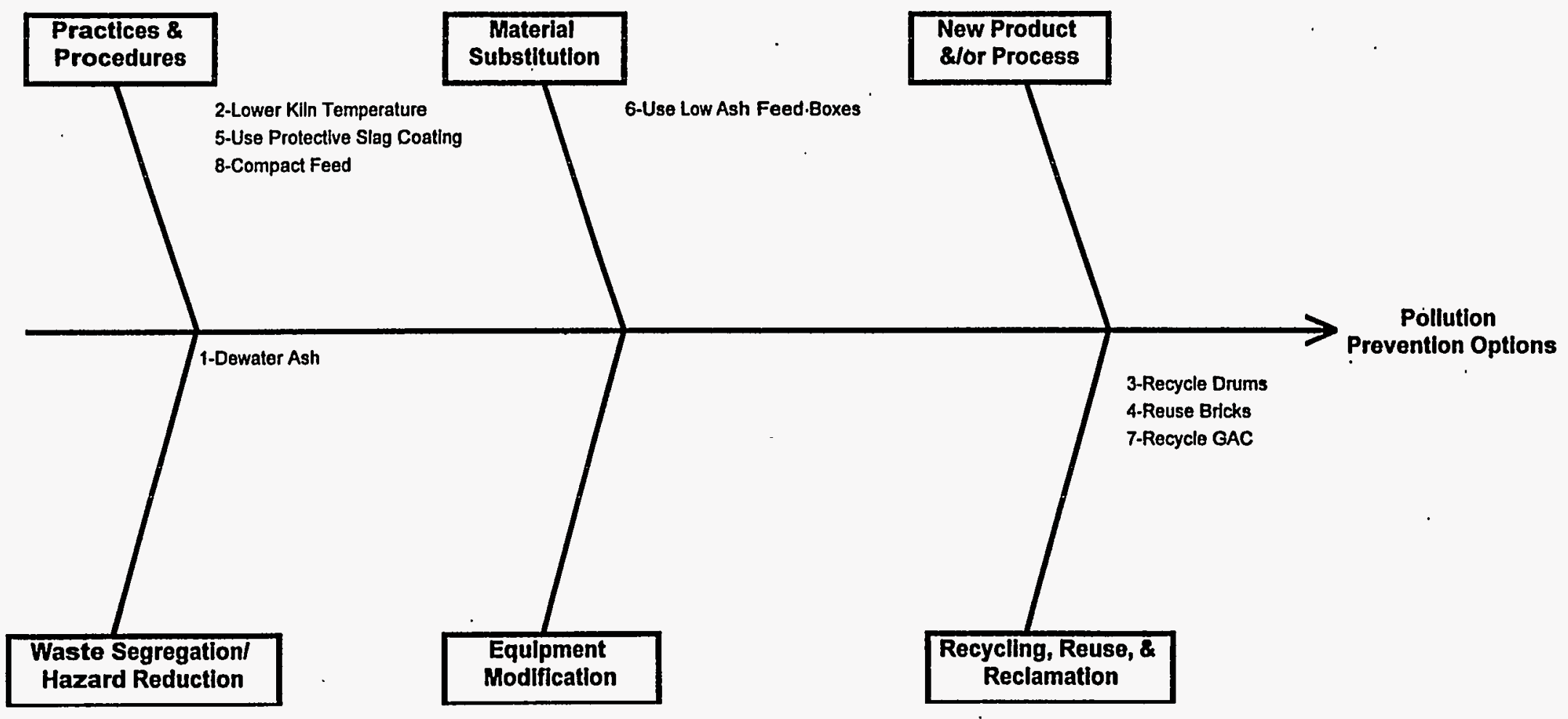




\section{Pollution Prevention Opportunity Assessment Option Description}

PPOA Title or PPOA ID Code: TSCA Kiln Operations

Option Name and Description

(Include input materials, products affected, and anticipated reduction quantity.)

Option No. 1 : Dewater ash before placing in drum to reduce volume -- ash dewatering to be considered in modified ash handling system under design.
Consider Option Further $\square$ Yes $\mathbf{X}_{\text {No }}$
Practices \& Procedure
Waste Segregation/Hazardous Reduction 区
Material Substitution
Equipment Modification
New Product \&/or Process
Recycle, Reuse, Reclamation

Option No. 2 . : Lower kiln temperature to extend brick life and reduce disposal quantity.

$$
\text { Consider Option Further } \quad \text { Yes } \square_{\text {No }}
$$

Practices \& Procedure

Material Substitution

New Product \&/or Process
凶 Waste Segregation/Hazardous Reduction

Equipment Modification

Recycle, Reuse, Reclamation

Option No. 3 : Use recycled drums for ash and sludge storage from kiln after inspection.

Consider Option Further $\quad$ Yes $\square$ No

Practices \& Procedure

Waste Segregation/Hazardous Reduction

Material Substitution

New Product \&/or Process
Equipment Modification

Recycle, Reuse, Reclamation $\otimes$ 


\section{Pollution Prevention Opportunity Assessment Option Description}

PPOA Title or PPOA ID Code: TSCA Kiln Operations

Option Name and Description

(Include input materials, products affected, and anticipated reduction quantity.)

Option No. 4 : Reuse bricks from kiln after testing -- bricks replaced due to damage from chemical attack or physical damage such as spalling.

. Consider Option Further $\square$ Yes $\nabla$ No

Practices \& Procedure

Waste Segregation/Hazardous Reduction

Material Substitution

Equipment Modification

New Product \&/or Process

Recycle, Reuse, Reclamation $\otimes$

Option No. 5 : Use protective slag coating as a working lining -- very difficult to make a dependable slag lining due to the variety of waste types incinerated.

\begin{tabular}{|c|c|c|c|}
\hline & & Consider Option Further $\quad \square$ Yes & 区 No \\
\hline & 凶 & Waste Segregation/Hazardous Reduction & $\square$ \\
\hline Iaterial Substitution & $\square$ & Equipment Modification & 口 \\
\hline y Product \&/or I & $\square$ & Recycle, Reuse, Reclamation & $\square$ \\
\hline
\end{tabular}

Option No. 6 : Use low ash feed boxes -- ash content of boxes already low.

Practices \& Procedure

Material Substitution

New Product \&/or Process
Consider Option Further $\square$ Yes $\quad$ No Waste Segregation/Hazardous Reduction

Equipment Modification

Recycle, Reuse, Reclamation 


\section{Pollution Prevention Opportunity Assessment Option Description}

PPOA Title or PPOA ID Code: TSCA Kiln Operations

Option Name and Description

(Include input materials, products affected, and anticipated reduction quantity.)

Option No. $7 \quad$ : Recycle GAC

\begin{tabular}{|c|c|c|c|}
\hline & & Consider Option Further & $\square$ No \\
\hline Practices \& Procedure & $\square$ & Waste Segregation/Hazardous Reduction & $\square$ \\
\hline Material Substitution & $\square$ & Equipment Modification & $\square$ \\
\hline New Product \&/or Process & $\square$ & Recycle, Reuse, Reclamation & 凶 \\
\hline
\end{tabular}

Option No. $8 \quad$ : Compact feed -- currently planned waste feeds do not need compaction.

Consider Option Further $\square$ Yes $\otimes$ No

Practices \& Procedure $\quad \square \quad$ Waste Segregation/Hazardous Reduction

Material Substitution

Equipment Modification

New Product \&/or Process

Recycle, Reuse, Reclamation 


\section{Pollution Prevention Opportunity Assessment Options Cost Evaluation}

PPOA Title or PPOA ID Code(s): TSCA Kiln Operations

\begin{tabular}{|l|c|c|c|}
\cline { 2 - 4 } \multicolumn{1}{l|}{} & Option No. & Option No. & Option No. \\
\cline { 2 - 4 } & 2-Kiln Temp. & 3-Recycle Drums & 7-Recycle GAC \\
\hline Purchased Equipment & & & \\
\hline Installation & & & \\
\hline Materials & & & \\
\hline Utility Connections & & & \\
\hline Engineering & & & \\
\hline Development & & & \\
\hline Start Up/Training & & & \\
\hline Administrative & & & \\
\hline Other & & & \\
\hline Total Implementation \\
Cost
\end{tabular}




\section{Pollution Prevention Opportunity Assessment}

Weighted Sums Options Evaluation

PPOA Title or PPOA ID Code(s): TSCA Kiln Operations

\begin{tabular}{|c|c|c|c|c|c|c|c|}
\hline & & & & & & \\
\hline & & \multirow{2}{*}{\multicolumn{2}{|c|}{$\begin{array}{c}\text { Option 2 } \\
\text { Kiln Temp }\end{array}$}} & \multirow{2}{*}{\multicolumn{2}{|c|}{$\begin{array}{c}\text { Option } 3 \\
\text { Recycle Drums }\end{array}$}} & \multirow{2}{*}{\multicolumn{2}{|c|}{$\begin{array}{c}\text { Option 7 } \\
\text { Recycle GAC }\end{array}$}} \\
\hline \multirow[t]{2}{*}{ Criteria } & \multirow[t]{2}{*}{ Weight (W) } & & & & & & \\
\hline & & Scale (S) & $\mathbf{W} * \mathbf{S}$ & Scale (S) & $\mathbf{W} * \mathbf{S}$ & Scale (S) & $\mathbf{W} * \mathbf{S}$ \\
\hline $\begin{array}{l}\text { Public Health, Safety, \& } \\
\text { Environment }\end{array}$ & 10 & 4 & 40 & 10 & 100 & 6 & 60 \\
\hline Employee Health \& Safety & 10 & 4 & 40 & 6 & 60 & 4 & 40 \\
\hline Regulatory Compliance & $\overline{8}$ & 2 & 16 & 4 & 32 & 4 & 32 \\
\hline Economic & $\overline{6}$ & 10 & 60 & 10 & 60 & 10 & $\overline{60}$ \\
\hline Implementation Period & $\overline{4}$ & 10 & 40 & $\overline{5}$ & 20 & 10 & 40 \\
\hline $\begin{array}{l}\text { Improved Operation / } \\
\text { Product }\end{array}$ & . & 4 & $\overline{8}$ & $\overline{5}$ & $\overline{10}$ & $\overline{10}$ & 20 \\
\hline Other & $\overline{0}$ & 0 & $\overline{0}$ & $\overline{0}$ & $\overline{0}$ & $\overline{0}$ & $\overline{0}$ \\
\hline Subtotal & & & 204 & & 282 & & 252 \\
\hline $\begin{array}{l}\text { Likelihood of Technical } \\
\text { Success (Multiplier) }\end{array}$ & & $\mathbf{X}$ & 0.2 & $\mathbf{X}$ & $\overline{0.8}$ & $\mathbf{X}$ & 1 \\
\hline $\begin{array}{l}\text { Likelihood of Useful } \\
\text { Results (Multiplier) }\end{array}$ & & $\overline{\mathbf{X}}$ & $\overrightarrow{0.8}$ & $\overline{\mathbf{X}}$ & $\overline{0.8}$ & $\mathbf{X}$ & $\overline{1}$ \\
\hline Total & & & 32.64 & & 180.48 & & 252 \\
\hline Rank & & & 2 & & & & \\
\hline
\end{tabular}




\title{
Pollution Prevention Opportunity Assessment Final Report Check Sheet
}

\author{
PPOA Title: TSCA Incinerator \\ PPOA ID Code: TSCA Kiln Operations
}

Requirement

Title Page

PPOA Title

PPOA Id Code

Team Members

Issue date/revision date/revision no.

Executive Summary

Process Description

Process Assessment

Option Summary and analysis

Conclusions

Recommendations

Introduction

Background of evaluation

Process Description

Associated Equipment

Process Flow Diagram

Process Assessment

Methodology

Material Balance

Unusual Occurrences

Option Summary and Analysis

Option Description and rank

Upstream/Downstream impacts

Material usage

Anticipated reduction

Estimated costs

Estimated benefits

Feasibility

Waste streams affected

Conclusion

Concluding evaluation

Option analysis decisions

Concerns

Options already implemented

Lessons leamed

Recommendations

Future work

New Equipment

Implementation strategies
Completed

$x$

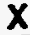

$\mathbf{X}$

$\mathbf{x}$

$\mathbf{x}$

$x$

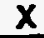

$\mathbf{x}$

$\mathbf{x}$ 
Appendix B

PPOA Worksheets

for Sump Operations 


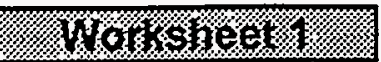

Level III
Revision No.: 0

Revision Date:9/08/95

\section{Pollution Prevention Opportunity Assessment PPOA Team}

PPOA Title: $\quad$ TSCA Incinerator

PPOA ID Code: Sump Operations

\begin{tabular}{lll} 
Name & Job Classification & Phone \\
\hline James T. Nelson & Sr. Environmental Engineer & $615 / 483-0666$ \\
Wiliam Nicholas & Sr. Environmental Engineer & $615 / 483-0666$ \\
Steven J. Kirslis & Environmental Engineer & $615 / 483-0666$ \\
Marshall A. Eaves & Project Engineer & $615 / 576-3974$ \\
James E. Dunn, Jr. & $\begin{array}{l}\text { Engineering and Analysis Department } \\
\text { Manager }\end{array}$ & $615 / 241-5751$ \\
W. Gerald Melton & $\begin{array}{l}\text { Manager-Waste and Residuals Management } \\
\text { Program }\end{array}$ & $615 / 241-2100$ \\
Fidel Perez & TSCA Incinerator Division Director & $615 / 576-5257$
\end{tabular}


B-4

Worksheêt?

Level III

Revision No:

2 .

Revision Date: $\quad$ 9/8/95

\section{Pollution Prevention Opportunity Assessment Process Description}

PPOA Title: TSCA Incinerator

PPOA ID Code: Sump Operations

Process Location: TSCA Incinerator - K-25 Site

Process Description: The ionizing wet scrubber (IWS) scrubs the off-gases from the TSCA Incinerator. TSCA/ IWS sludge is collected in sumps, and dewatered with a filter press. The filter cake is drummed for disposal while the filtrate is combined with firewater and rainwater from the process area. This combined wastewater is filtered with activated carbon, and then discharged from the incinerator site to the Central Neutralization Facility.

Description of Major Product(s) of Process:

TSCA wastewater,TSCA/ IWS filtercake, spent GAC, 


\section{Pollution Prevention Opportunity Assessment \\ Process Flow Diagram}

PPOA Title or PPOA ID Code(s): Sump Operations

Inputs:

GAC

New Drums

Wastewater

$-$ 


\section{Pollution Prevention Opportunity Assessment}

\section{Material Balance Summary}

PPOA Title or PPOA ID Code(s): Sump Operations

Output Quantity Units: KG

\begin{tabular}{|c|c|c|c|}
\hline \multirow[t]{2}{*}{ Material Description } & \multirow{2}{*}{$\begin{array}{c}\text { Total } \\
\text { Output }\end{array}$} & $\begin{array}{l}\text { Stream } \\
\text { ID Code }\end{array}$ & $\begin{array}{l}\text { Stream } \\
\text { ID Code }\end{array}$ \\
\hline & & MX1 & $\mathrm{MX2}$ \\
\hline Wasttwater & $75,467,200$ & $\overline{0}$ & $75,467,200$ \\
\hline Filtercake & 52,829 & 52,829 & 0 \\
\hline$\overline{\mathrm{GAC}}$ & $\overline{5,047}$ & $\overline{5,047}$ & $\overline{0}$ \\
\hline Totals/Subtotals & $75,525,076$ & 57,876 & $75,467,200$ \\
\hline
\end{tabular}




\section{Pollution Prevention Opportunity Assessment}

\section{Input Material and Output Disposal Cost}

PPOA Title or PPOA ID Code: Sump Operations

Input Material Cost:

\begin{tabular}{|c|c|c|c|}
\hline Material & Quantity (kg) & Cost Per Unit & Annual Cost \\
\hline Wastewater & $75,467,196.00$ & 0.0003 & $\$ 22,640.16$ \\
\hline GAC & $5,047.00$ & 2.2 & $\$ 11,103.40$ \\
\hline New Drums & 256.00 & 30.75 & $\$ 7,872.00$ \\
\hline Total/Subtotal & $75,472,499.00$ & & $\$ 41,615.56$ \\
\hline
\end{tabular}

Waste Disposal Cost:

\begin{tabular}{|c|c|c|c|c|}
\hline Material/Waste Stream & $\begin{array}{c}\text { Stream } \\
\text { Code }\end{array}$ & Qty (kg) & Cost Per Unit & Annual Cost \\
\hline Wastewater & $M X 2$ & $75,467,200$ & 0.03 & $\$ 2,264,016.00$ \\
\hline Filtercake & $\mathrm{MX1}$ & 52,829 & 2 & $\$ 105,658.00$ \\
\hline GAC & $\mathrm{MX1}$ & 5,047 & 6 & $\$ 30,282.00$ \\
\hline Total/Subtotal & & $75,525,076$ & & $\$ 2,399,956.00$ \\
\hline
\end{tabular}




\section{Pollution Prevention Opportunity Assessment Option Generation}

PPOA Title or PPOA ID Code: Sump Operations

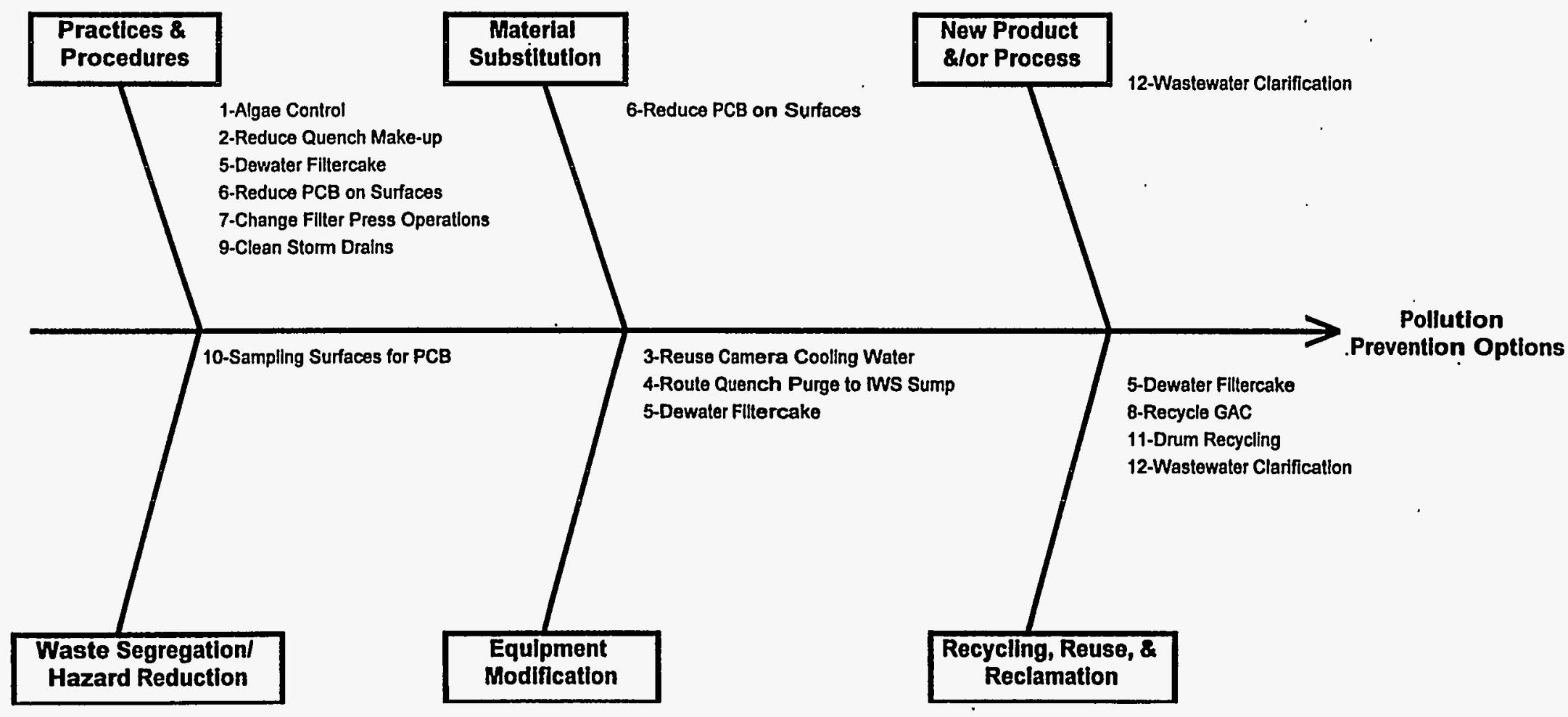


PPOA Title or PPOA ID Code: Sump Operations

Option Name and Description

(Include input materials, products affected, and anticipated reduction quantity.)

Option No. 1 : Algae control in firewater sump.

$$
\text { Consider Option Further } \quad \text { Yes } \square \text { No }
$$

Practices \& Procedure $\quad$ $\quad$ Waste Segregation/Hazardous Reduction

Material Substitution

Equipment Modification

New Product \&/or Process

Recycle, Reuse, Reclamation

Option No. 2 : Reduce quench makeup water rate to $35 \mathrm{gpm}$ when not incinerating wastes.

$$
\text { Consider Option Further } \square \text { Yes } \square \text { No }
$$

Practices \& Procedure

Material Substitution

New Product \&/or Process
Waste Segregation/Hazardous Reduction

Equipment Modification

Recycle, Reuse, Reclamation

Option No. $3 \quad$ : Reroute kiln and secondary combustion chamber camera cooling water in series to reduce wastewater generation.

Consider Option Further $\square$ Yes $\square$ No

Practices \& Procedure

Material Substitution

New Product \&/or Process
Waste Segregation/Hazardous Reduction

Equipment Modification $\otimes$

Recycle, Reuse, Reclamation 


\section{Pollution Prevention Opportunity Assessment Option Description}

PPOA Title or PPOA ID Code: Sump Operations

Option Name and Description

(Include input materials, products affected, and anticipated reduction quantity.)

Option No. $4 \quad$ : Reroute low TDS Quench Purge to IWS makeup to reduce water use.

Consider Option Further $\quad$ Yes $\square$ No

Practices \& Procedure

Material Substitution

New Product \&/or Process
Waste Segregation/Hazardous Reduction

Equipment Modification $\bigotimes$

Recycle, Reuse, Reclamation

Option No. $5 \quad$ : Remove free water from filter cake.

\begin{tabular}{|c|c|c|c|}
\hline & & Consider Option Further $\square$ Yes & 区 \\
\hline Practices \& Procedure & 凶 & Waste Segregation/Hazardous Reduction & \\
\hline Material Substitution & $\square$ & Equipment Modification & \\
\hline New Product \&/or Process & $\square$ & Recycle, Reuse, Reclamation & \\
\hline
\end{tabular}

Option No. 6 : Reduce PCB on exterior surfaces -- not beneficial if storm drain is not decontaminated.

Consider Option Further $\square$ Yes $\bigotimes$ No

Practices \& Procedure · $\quad$ Waste Segregation/Hazardous Reduction

Material Substitution $\square$

Equipment Modification

New Product \&/or Process

Recycle, Reuse, Reclamation 


\section{Pollution Prevention Opportunity Assessment Option Description}

PPOA Title or PPOA ID Code: Sump Operations

Option Name and Description

(Include input materials, products affected, and anticipated reduction quantity.)

Option No. 7 : Improve filter press operations-- currently underway by TSCA operations.

Consider Option Further $\square$ Yes $\quad$ No

Practices \& Procedure $\quad$ 囚

Material Substitution

New Product \&/or Process
Waste Segregation/Hazardous Reduction

Equipment Modification

Recycle, Reuse, Reclamation

Option No. $8 \quad$ : Recycle GAC. See Option 7 of Kiln Operations.

Consider Option Further $\square$ Yes $\square$ No

Practices \& Procedure Waste Segregation/Hazardous Reduction

Material Substitution Equipment Modification

New Product \&/or Process Recycle, Reuse, Reclamation $\otimes$

Option No. 9 : Clean storm drains -- complete decontamination was considered technically unfeasible

$\begin{array}{llrl} & & \text { Consider Option Further } \quad \square \text { Yes } & \square \text { No } \\ \text { Practices \& Procedure } & \bigotimes & \text { Waste Segregation/Hazardous Reduction } & \square \\ \text { Material Substitution } & \square & \text { Equipment Modification } & \square \\ \text { New Product \&/or Process } & \square & \text { Recycle, Reuse, Reclamation } & \square\end{array}$




\section{Pollution Prevention Opportunity Assessment Option Description}

PPOA Title or PPOA ID Code: Sump Operations

Option Name and Description

(Include input materials, products affected, and anticipated reduction quantity.)

Option No. 10 : Sampling to determine sources of PCB's - not beneficial if storm drain is not decontaminated.

$\begin{array}{llrl} & & \text { Consider Option Further } \quad \square \text { Yes } & \text { No } \\ \text { Practices \& Procedure } & \square & \text { Waste Segregation/Hazardous Reduction } & \otimes \\ \text { Material Substitution } & \square & \text { Equipment Modification } & \square \\ \text { New Product \&/or Process } & \square & \text { Recycle, Reuse, Reclamation } & \square\end{array}$

Option No. 11 - : Drum recycling -- drums found to be rusted and therfore unrecyclable.

Practices \& Procedure

Material Substitution

New Product \&/or Process
Consider Option Further $\square$ Yes

区 No

Equipment Modification

Recycle, Reuse, Reclamation $\bigotimes$

Option No. 12 : Clarifier - to reduce solids and enable reduction of quench water rate

Practices \& Procedure

Material Substitution

New Product \&/or Process $\bigotimes$

$$
\text { Consider Option Further } \square \text { Yes } \quad \text { No }
$$

Waste Segregation/Hazardous Reduction

Equipment Modification

Recycle, Reuse, Reclamation $\bigotimes$ 
Revision No.: 1

Level III

Revision Date:

$8 / 21 / 95$

Page 1

of 1

\title{
Pollution Prevention Opportunity Assessment
}

\author{
Options Cost Evaluation
}

PPOA Title or PPOA ID Code(s): Sump Operations

\begin{tabular}{|c|c|c|c|c|}
\hline & Option No. & Option No. & Option No. & Option No. \\
\hline & 1-Algae control & 2- Quench Make-up & 3-Camera Water & 4-Quench Purge \\
\hline \multicolumn{5}{|c|}{ 6. } \\
\hline Purchased Equipment & $\$ 10,000$ & & $\$ 1,950$ & $\$ 9,400$ \\
\hline Installation & $\$ 5,000$ & $\$ 400$. & $\$ 6,283$. & $\$ 28,895$ \\
\hline \multicolumn{5}{|l|}{ Materials } \\
\hline \multicolumn{5}{|l|}{ Utility Connections } \\
\hline Engineering & $\$ 5,000$. & & $\$ 3,129$ & $\$ 9,200$ \\
\hline Development & $\$ 1,000$ & $\$ 800$. & $\$ 638$. & \\
\hline \multicolumn{5}{|l|}{ Start Up/Training } \\
\hline Administrative ${ }^{\circ}$ & & & $\$ 2,000$ & $\$ 6,300$ \\
\hline Other & & & $\$ 8,000$. & $\$ 19,500$. \\
\hline $\begin{array}{l}\text { Total Implementation } \\
\text { Cost }\end{array}$ & $\$ 21,000$ & $\$ 1,200$ & $\$ 22,000$ & $\$ 73,295$ \\
\hline \multicolumn{5}{|c|}{ 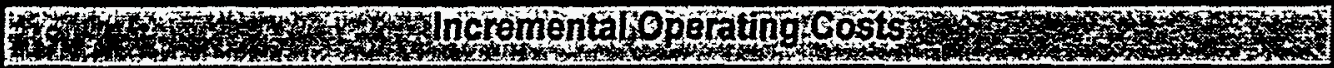 } \\
\hline Change in Raw Materials & $\$ 2,776$ & $\$ 5,606$ & & $\$ 4,214$ \\
\hline Change in Maintenance & $(\$ 1,000)$. & & & \\
\hline \multicolumn{5}{|l|}{ Change in Labor } \\
\hline Change in Disposal & $\$ 7,572$ & $\$ 417,475$ & $\$ 261,696$. & $\$ 315,147$. \\
\hline \multicolumn{5}{|l|}{ Change in Utilities } \\
\hline Other & & $\$ 76,900$ & $\$ 51,500$ & $\$ 57,800$. \\
\hline $\begin{array}{l}\text { Annual Operating } \\
\text { Savings/(Costs) }\end{array}$ & $\$ 9,348$ & $\$ 499,981$ & $\$ 313,196$ & $\$ 377,161$ \\
\hline \multicolumn{5}{|c|}{ (3) } \\
\hline Penalties and Fines & $\cdot$ & & . & \\
\hline \multicolumn{5}{|l|}{ Future Liabilities } \\
\hline \multicolumn{5}{|l|}{ Other } \\
\hline \multicolumn{5}{|l|}{$\begin{array}{l}\text { Annual Intangible } \\
\text { Savings/(Cost) }\end{array}$} \\
\hline Pay-back Period & 2.25 & 0.002 & .07 & .19 \\
\hline
\end{tabular}




\begin{tabular}{|c|c|c|c|c|c|c|c|c|c|}
\hline$t$ & & $\varepsilon$ & & $z$ & & I & & & YuEy \\
\hline $0 t$ & & 022 & & $0 z 2$ & & 882 & & & [E]0】 \\
\hline 20 & $\mathbf{x}$ & I & $\mathbf{X}$ & 1 & $\mathbf{X}$ & I & $\mathbf{x}$ & & 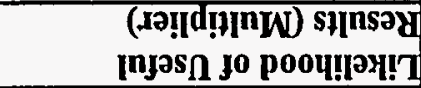 \\
\hline I & $\mathbf{x}$ & I & $\mathbf{x}$ & $I$ & $\mathbf{X}$ & I & $\mathbf{X}$ & & 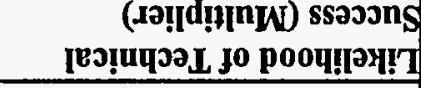 \\
\hline 002 & & $0 z 2$ & & $0 z 2$ & & $88 \tau$ & & & jełopqnS \\
\hline 0 & 0 & 0 & 0 & 0 & 0 & 0 & 0 & 0 & səu10 \\
\hline ZI & 9 & 8 & tb & 8 & $t$ & $0 z$ & IOI & $z$ & 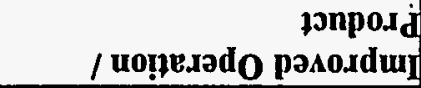 \\
\hline $9 \mathrm{l}$. & $t$ & $0 t$ & $0 \mathrm{I}$ & ot & $0 \mathrm{I}$ & $0 t$ & OI & to & 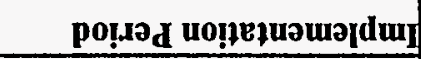 \\
\hline 09 & $0 \mathrm{I}$ & 09 & $0 \mathrm{I}$ & 09 & OI & 09 & OI & 9 & ग̣uourojg \\
\hline$z \varepsilon$ & $t$ & 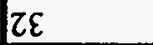 & to & 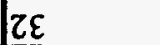 & It & $8 t$ & 9 & 8 & 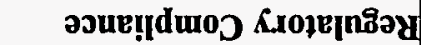 \\
\hline $0 t$ & t & $0 t$ & t & ot & t & 09 & 9 & $0 I$ & 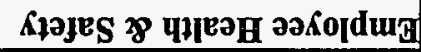 \\
\hline 00 & t & ot & to & $0 t$ & $t$ & 09 & 9 & OI & 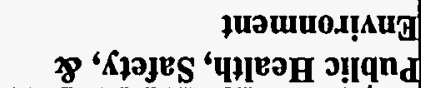 \\
\hline $\mathbf{S} * \mathbf{M}$ & (S) गएеग & $\mathbf{S} * \mathbf{M}$ & (S) әреगS & $\mathbf{S} * \mathbf{M}$ & (S) əןยว & $\mathbf{S} * \mathbf{M}$ & (S) ə[ย्S & \multirow[b]{2}{*}{ 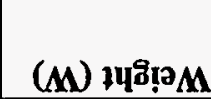 } & \multirow[b]{2}{*}{ 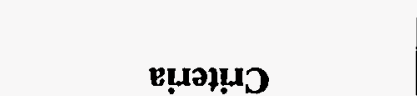 } \\
\hline \multicolumn{2}{|c|}{ 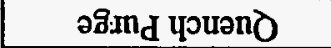 } & \multicolumn{2}{|c|}{ 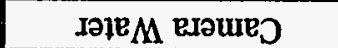 } & \multicolumn{2}{|c|}{ dn-əY⿱氏W YJuənठ } & \multicolumn{2}{|c|}{ 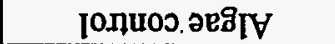 } & & \\
\hline
\end{tabular}

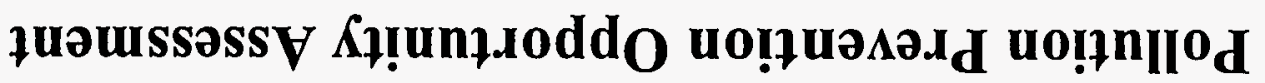




\section{Pollution Prevention Opportunity Assessment Final Report Check Sheet}

$\begin{array}{ll}\text { PPOA Title: } & \text { TSCA Incinerator } \\ \text { PPOA ID Code: } & \text { Sump Operations }\end{array}$

Requirement

Completed

Title Page

$x$

PPOA Title

PPOA Id Code

Team Members

Issue date/revision date/revision no.

Executive Summary

$\mathbf{x}$

Process Description

Process Assessment

Option Summary and analysis

Conclusions

Recommendations

Introduction

Background of evaluation

Process Description

Associated Equipment

Process Flow Diagram

Process Assessment

Methodology

Material Balance

Unusual Occurrences

Option Summary and Analysis

Option Description and rank

Upstream/Downstream impacts

Material usage

Anticipated reduction

Estimated costs

Estimated benefits

Feasibility

Waste streams affected

Conclusion

Concluding evaluation

Option analysis decisions

Concerns

Options already implemented

Lessons learned

Recommendations

Future work

New Equipment

Implementation strategies

Worksheets

$x$

$\mathbf{x}$

$\mathbf{x}$

$x$

$\mathrm{x}$ 


\author{
Appendix C \\ PPOA Worksheets \\ for Tank/Tanker Operations
}



C-3

11 18 s

Level III
Revision No.: 0

Revision Date:9/08/96

\title{
Pollution Prevention Opportunity Assessment PPOA Team
}

\author{
PPOA Title: $\quad$ TSCA Incinerator \\ PPOA ID Code: TankTanker Operations
}

\begin{tabular}{lll} 
Name & Job Classification & Phone \\
\hline \hline James T. Nelson & Sr. Environmental Engineer & $615 / 483-0666$ \\
Wiliam Nicholas & Sr. Environmental Engineer & $615 / 483-0666$ \\
Steven J. Kirslis & Environmental Engineer & $615 / 483-0666$ \\
Marshall A. Eaves & Project Engineer & $615 / 576-3974$ \\
James E. Dunn, Jr. & Engineering and Analysis Department & $615 / 241-5751$ \\
W. Gerald Melton & Manager & \\
& $\begin{array}{l}\text { Manager-Waste and Residuals Management } \\
\text { Fidel Perez }\end{array}$ & $615 / 241-2100$ \\
& TSCA Incinerator Division Director & $615 / 576-5257$
\end{tabular}


C-4

Worksheet2

Level III

Revision No:

2

Revision Date:

$9 / 8 / 95$

\section{Pollution Prevention Opportunity Assessment}

\section{Process Description}

PPOA Title: TSCA Incinerator

PPOA ID Code: Tank/Tanker Operations

Process Location: TSCA Incinerator

Process Description: Tanker trucks are cleaned, decontaminated, unloaded, and leak/pressure tested at the TSCA Incinerator Tank Farm.

Cleaning and decontamination activities generate

PCB/RAD/RCRA contaminated diesel fuel. Tankers haul radioactive, PCB - contaminated, and RCRA solvents from $\mathrm{K}-1420-\mathrm{A}$ to the TSCA Incinerator tank area where they are unloaded. Tanks at the TSCA Incinerator are vented through granular activated carbon and cleaned intermittently. Used PPE, diapers, and spill residue may also be generated during these activities. Tanks and tankers are hydrostatically tested; the resulting contaminated wastewater is processed through the TSCA Incinerator.

Description of Major Product(s) of Process:

RCRA/ RAD/ PCB - contaminated diesel fuel, RCRA/ RAD/ PCB - contaminated water from testing 


\section{Pollution Prevention Opportunity Assessment Process Flow Diagram}

PPOA Title or PPOA ID Code(s): Tank/Tanker Operations

\section{Inputs:}

Diesel fuel

GAC

Contaminated Water

Sludge

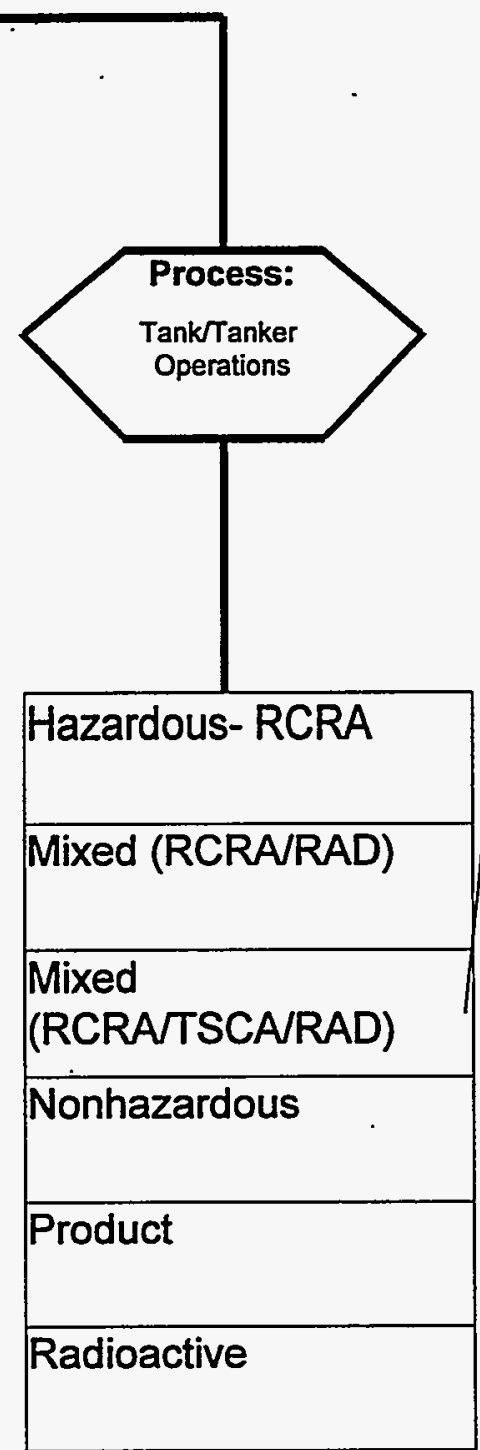

\begin{tabular}{|l|l|l|}
\hline MX1 & Solid & GAC \\
\hline MX2 & Liquid & Diesel Fuel \\
\hline MX2 & Liquid & Sludge \\
\hline MX2 & Liquid & Contaminated Water \\
\hline
\end{tabular}




\section{Pollution Prevention Opportunity Assessment}

\section{Material Balance Summary}

PPOA Title or PPOA ID Code(s): Tank/Tanker Operations

Output Quantity Units: $\mathrm{Kg}$

\begin{tabular}{|c|c|c|c|}
\hline \multirow[t]{2}{*}{ Material Description } & \multirow[t]{2}{*}{$\begin{array}{l}\text { Total } \\
\text { Output }\end{array}$} & $\begin{array}{l}\text { Stream } \\
\text { ID Code }\end{array}$ & $\begin{array}{l}\text { Stream } \\
\text { ID Code }\end{array}$ \\
\hline & & $\overline{\mathrm{MXI}}$ & MX2 \\
\hline Sludge & 0 & $\overline{0}$ & 0 \\
\hline$\overline{\mathrm{GAC}}$ & 405 & 405 & $\overline{0}$ \\
\hline Diesel Fuel & 108,000 & 0 & 108,000 \\
\hline Contaminated Water & 56,000 & 0 & 56,000 \\
\hline Totals/Subtotals & 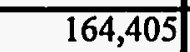 & 405 & 164,000 \\
\hline
\end{tabular}




\section{Pollution Prevention Opportunity Assessment}

\section{Input Material and Output Disposal Cost}

PPOA Title or PPOA ID Code: TankTTanker Operations

Input Material Cost:

\begin{tabular}{|c|c|c|c|}
\hline Material & Quantity (kg) & Cost Per Unit & Annual Cost \\
\hline Sludge & 0.00 & 0 & $\$ 0.00$ \\
\hline Contaminated Water & $56,000.00$ & 0.009 & $\$ 504.00$ \\
\hline Diesel fuel & $108,000.00$ & 0.26 & $\$ 28,080.00$ \\
\hline$\overline{G A C}$ & 405.00 & 2.2 & $\$ 891.00$ \\
\hline Total/Subtotal & $164,405.00$ & & $\$ 29,475.00$ \\
\hline
\end{tabular}

Waste Disposal Cost:

\begin{tabular}{|c|c|c|c|c|}
\hline Material/Waste Stream & $\begin{array}{c}\text { Stream } \\
\text { Code }\end{array}$ & Qty (kg) & Cost Per Unit & Annual Cost \\
\hline Sludge & $\mathrm{M} \times 2$ & 0 & 0 & $\$ 0.00$ \\
\hline$\overline{G A C}$ & $\mathrm{MX1}$ & 405 & 6 & $\$ 2,430.00$ \\
\hline Contaminated Water & $\overline{M X 2}$ & 56,000 & 11 & $\$ 616,000.00$ \\
\hline Diesel Fuẹl & MX2 & 108,000 & 11 & $\$ 1,188,000.00$ \\
\hline Total/Subtotal & & 164,405 & & $\$ 1,806,430.00$ \\
\hline
\end{tabular}




\section{Pollution Prevention Opportunity Assessment Option Generation}

PPOA Title or PPOA ID Code: Tank/Tanker Operations

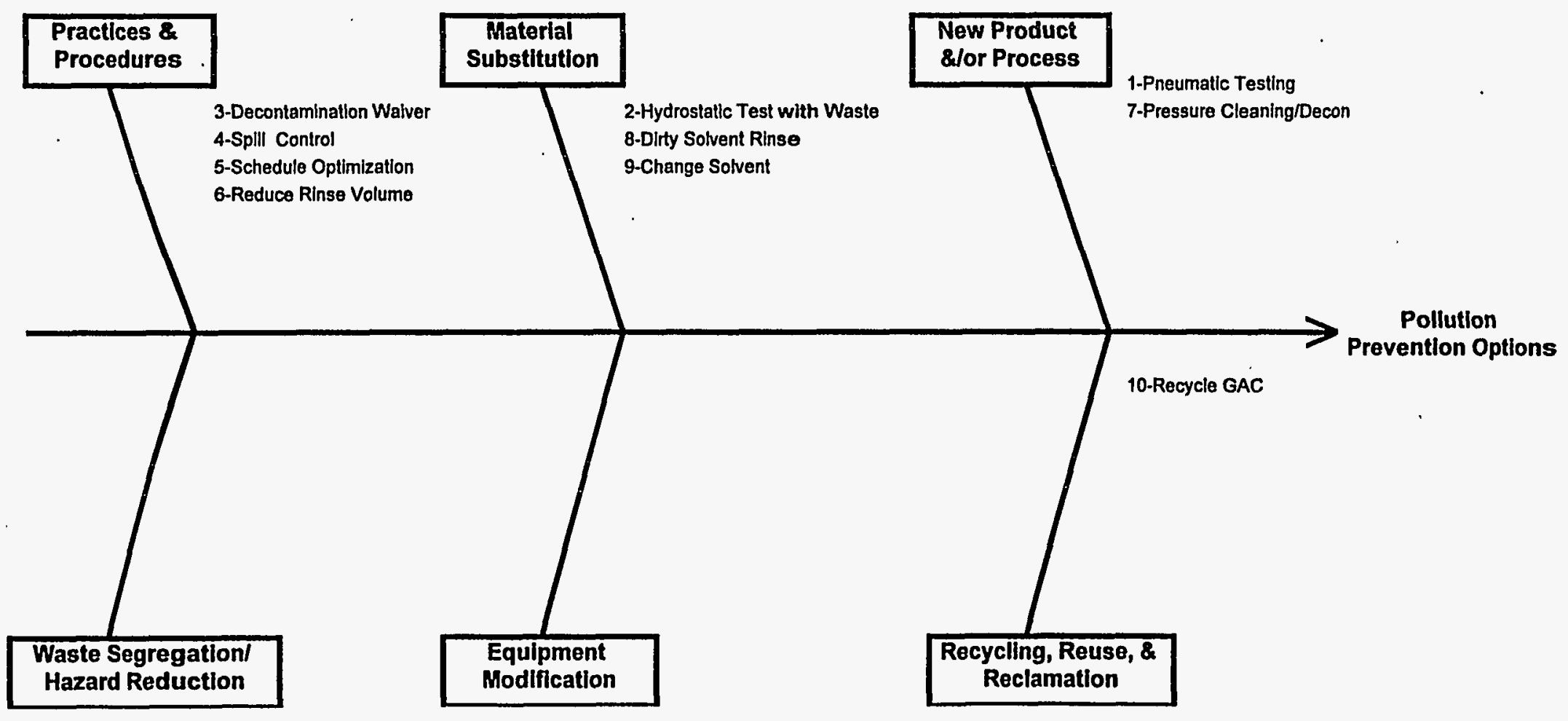




\section{Pollution Prevention Opportunity Assessment Option Description}

PPOA Title or PPOA ID Code: Tank/Tanker Operations

Option Name and Description

(Include input materials, products affected, and anticipated reduction quantity.)

Option No. 1 : Pneumatic testing- use pneumatic testing (49 CFR 180.407) with nitrogen atmosphere instead of hydrostatic testing for tankers.

\begin{tabular}{|c|c|c|c|}
\hline & & Consider Option Further & $\square$ No \\
\hline Practices \& Procedure & $\square$ & Waste Segregation/Hazardous Reduction & $\square$ \\
\hline Material Substitution & $\square$ & Equipment Modification & \\
\hline New Product \&/or Process & $凶$ & Recycle, Reuse, Reclamation & $\square$ \\
\hline
\end{tabular}

Option No. 2 : Use solvent waste for hydrostatic tank/tanker testing instead of water.
Practices \& Procedure
Material Substitution
Waste Segregation/Hazardous Reduction
New Product \&/or Process
Equipment Modification
Recycle, Reuse, Reclamation

Consider Option Further $\quad$ Yes $\square$ No

Option No. 3 : Cleaning/ decontamination- reduce interval for cleaning or get waiver for decontamination of dedicated tank trucks.
Consider Option Further $\bigotimes$ Yes $\square$ No
Practices \& Procedure $\otimes$
Material Substitution
New Product \&/or Process

\author{
Waste Segregation/Hazardous Reduction \\ Equipment Modification \\ Recycle, Reuse, Reclamation
}




\section{Pollution Prevention Opportunity Assessment Option Description}

PPOA Title or PPOA ID Code: Tank/Tanker Operations

Option Name and Description

(Include input materials, products affected, and anticipated reduction quantity.)

Option No. $4 \quad$ : Spill control- standardize spill control procedure to reduce waste.

Consider Option Further $\square$ Yes $\quad$ No

Practices \& Procedure $\quad$ Q

Material Substitution

New Product \&/or Process
区 Waste Segregation/Hazardous Reduction

Equipment Modification

Recycle, Reuse, Reclamation

Option No. $5 \quad$ : Scheduling- reduce cleanout interval for tank trucks by scheduling low solid wastes prior to high solid wastes.

Practices \& Procedure $\square$

Material Substitution

New Product \&/or Process

\author{
Consider Option Further $\square$ Yes $\otimes$ No \\ Waste Segregation/Hazardous Reduction \\ Equipment Modification \\ Recycle, Reuse, Reclamation
}

Option No. 6 : Reduce diesel fuel usage- Reduce amount of diesel fuel for tanker cleaning/ decontamination.

Consider Option Further $\square$ Yes $\quad$ No

Practices \& Procedure $\quad$ Waste Segregation/Hazardous Reduction

Material Substitution

Equipment Modification

New Product \&/or Process

Recycle, Reuse, Reclamation 


\section{Pollution Prevention Opportunity Assessment Option Description}

\section{PPOA Title or PPOA ID Code: Tank/Tanker Operations}

\section{Option Name and Description}

(Include input materials, products affected, and anticipated reduction quantity.)

Option No. $7 \quad$ : Pressure cleaning- clean/decontaminate tank trucks with high pressure spray instead of fill/slosh. Reduce diesel fuel usage from 1800 gal. to $200 \mathrm{gal}$.

Consider Option Further $\unrhd$ Yes $\square$ No

Practices \& Procedure

Material Substitution

New Product \&/or Process 区
Waste Segregation/Hazardous Reduction

Equipment Modification

Recycle, Reuse, Reclamation

Option No. $8 \quad$ : Dirty solvent- use "dirty" diesel fuel from another source for first two tanker rinses and continue using current procedure.

Consider Option Further $\square$ Yes $\bigotimes$ No

Practices \& Procedure

Material Substitution

区

New Product \&/or Process
Waste Segregation/Hazardous Reduction

Equipment Modification

Recycle, Reuse, Reclamation

Option No. 9 : Use solvent other than diesel fuel to clean/decontaminate tanker.

$$
\text { Consider Option Further } \square \text { Yes } \bigotimes \text { No }
$$

Practices \& Procedure

Material Substitution

凶
Waste Segregation/Hazardous Reduction

Equipment Modification

Recycle, Reuse, Reclamation 


\section{Pollution Prevention Opportunity Assessment Option Description}

\section{PPOA Title or PPOA ID Code: Tank/Tanker Operations}

Option Name and Description

(Include input materials, products affected, and anticipated reduction quantity.)

Option No. $10 \quad$ : Recycle GAC from Tank Farm Vents. See option 7 of Kiln Operations.

$$
\text { Consider Option Further } \square \text { Yes } \quad \text { No }
$$

Practices \& Procedure

Material Substitution

New Product \&/or Process
Waste Segregation/Hazardous Reduction

Equipment Modification $\square$

Recycle, Reuse, Reclamation 凶 


\section{Pollution Prevention Opportunity Assessment Options Cost Evaluation}

PPOA Title or PPOA ID Code(s): Tank/Tanker Operations

\begin{tabular}{|c|c|c|c|c|}
\hline & Option No. & Option No. & Option No. & Option No. \\
\hline & 1.PNEUMATIC TEST & 2HYDROTEST & 3-DECONWANER & 7-PRESSURE CLEAN \\
\hline \multicolumn{5}{|c|}{ 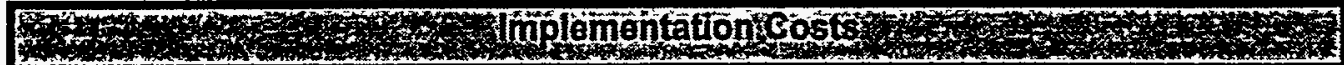 } \\
\hline Purchased Equipment & & & & $\$ 28,000$ \\
\hline Installation & & & & $\$ 5,000$ \\
\hline Materials & & & & $\$ 10,000$ \\
\hline Utility Connections & & & & $\$ 30,000$. \\
\hline Engineering & & & & $\$ 30,000$ \\
\hline \multicolumn{5}{|l|}{ Development } \\
\hline Start Up/Training & & & & $\$ 2,600$ \\
\hline Administrative & $\$ 1,000$ & $\$ 1,000$ & $\$ 1,000$ & $\$ 440$. \\
\hline Other & & & & $\$ 2,700$ \\
\hline $\begin{array}{l}\text { Total Implementation } \\
\text { Cost }\end{array}$ & $\$ 1,000$ & $\$ 1,000$ & $\$ 1,000$ & $\$ 108,740$ \\
\hline \multicolumn{5}{|c|}{ 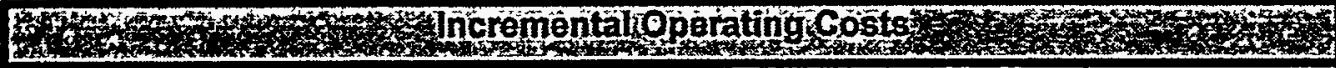 } \\
\hline Change in Raw Materials & $\$ 34$. & $\$ 34$. & $\$ 5,400$ & \\
\hline \multicolumn{5}{|l|}{ Change in Maintenance } \\
\hline Change in Labor & $(\$ 1,200)$. & $(\$ 1,200)$. & & \\
\hline Change in Disposal & $\$ 616,000$. & $\$ 616,000$ & $\$ 237,000$. & $\$ 784,080$. \\
\hline Change in Utilities & & & & $(\$ 10,000)$. \\
\hline \multicolumn{5}{|l|}{ Other } \\
\hline $\begin{array}{l}\text { Annual Operating } \\
\text { Savings/(Costs) }\end{array}$ & $\$ 614,834$. & $\$ 614,834$ & $\$ 242,400$ & $\$ 774,080$. \\
\hline \multicolumn{5}{|c|}{ Hot } \\
\hline Penalties and Fines & . & & & \\
\hline \multicolumn{5}{|l|}{ Future Liabilities } \\
\hline \multicolumn{5}{|l|}{ Other } \\
\hline \multicolumn{5}{|l|}{$\begin{array}{l}\text { Annual lntangible } \\
\text { Savings/(Cost) }\end{array}$} \\
\hline Pay-back Period & 0.0016 & 0.0016 & 0,0041 & .14 \\
\hline
\end{tabular}




\section{Pollution Prevention Opportunity Assessment}

\section{Weighted Sums Options Evaluation}

PPOA Title or PPOA ID Code(s): Tank/Tanker Operations

\begin{tabular}{|c|c|c|c|c|c|c|c|c|c|}
\hline & & & & & & & & \multirow{2}{*}{\multicolumn{2}{|c|}{ Option 7}} \\
\hline & \multicolumn{2}{|c|}{ Option 1 } & \multicolumn{2}{|c|}{ Option 2 } & \multicolumn{2}{|c|}{ Option 3} & & \\
\hline \multirow[t]{2}{*}{ Criteria } & \multirow[t]{2}{*}{ Weight (W) } & \multicolumn{2}{|c|}{ PNEUMATIC TEST } & \multicolumn{2}{|c|}{ HYDRO TEST } & \multicolumn{2}{|c|}{ DECON WAIVER } & \multicolumn{2}{|c|}{ PRESSURE CLEAN } \\
\hline & & Scale (S) & $\bar{W}{ }^{*} \mathbf{S}$ & Scale (S) & $\mathbf{W} * \mathbf{S}$ & Scale (S) & $\mathbf{W} * \mathbf{S}$ & Scale (S) & $W * S$ \\
\hline $\begin{array}{l}\text { Public Health, Safety, \& } \\
\text { Environment }\end{array}$ & 10 & 8 & 80 & 8 & 80 & 6 & 60 & 8 & 80 \\
\hline Employee Health \& Safety & 10 & 4 & 40 & $\overline{4}$ & $\overline{40}$ & 6 & 60 & $\overline{6}$ & $\overline{60}$ \\
\hline Regulatory Compliance & 8 & 4 & 32 & $\overline{4}$ & 32 & 4 & 32 & $\overline{4}$ & 32 \\
\hline Economic & $\overline{6}$ & 10 & 60 & 10 & $\overline{60}$ & 10 & 60 & 10 & 60 \\
\hline Implementation Period & $\overline{4}$ & 10 & 40 & 7 & 28 & 8 & 32 & 8 & 32 \\
\hline $\begin{array}{l}\text { Improved Operation / } \\
\text { Product }\end{array}$ & 2 & 4 & 8 & $\overline{4}$ & 8 & 4 & $\overline{8}$ & $\overline{8}$ & 16 \\
\hline Other & $\overline{0}$ & 0 & 0 & $\overline{0}$ & $\overline{0}$ & $\overline{0}$ & $\overline{0}$ & $\overline{0}$ & $\overline{0}$ \\
\hline Subtotal & & & 260 & & 248 & & 252 & & 280 \\
\hline $\begin{array}{l}\text { Likelihood of Technical } \\
\text { Success (Multiplier) }\end{array}$ & & $\overline{\mathbf{X}}$ & $\overline{1}$ & $\mathbf{X}$ & $\overline{1}$ & $\mathbf{X}$ & 1 & $\mathbf{x}$ & 1 \\
\hline $\begin{array}{l}\text { Likelihood of Useful } \\
\text { Results (Multiplier) }\end{array}$ & & $\overline{\mathbf{X}}$ & 1 & $\mathbf{X}$ & 1 & $\mathbf{X}$ & 1 & $\overline{\mathbf{X}}$ & 1 \\
\hline Total & & & 260 & & 248 & & 252 & & 280 \\
\hline Rank & & & 2 & & 3 & & 4 & & 1 \\
\hline
\end{tabular}


C-15

Workswee: 20

Revision No.: 1

Level III

Revision Date: 8/22/95

\section{Pollution Prevention Opportunity Assessment Final Report Check Sheet}

$\begin{array}{ll}\text { PPOA Title: } & \text { TSCA Incinerator } \\ \text { PPOA ID Code: } & \text { Tank/Tanker Operations }\end{array}$

\section{Requirement}

Title Page

PPOA Title

PPOA Id Code

Team Members

Issue date/revision date/revision no.

Executive Summary

Process Description

Process Assessment

Option Summary and analysis .

Conclusions

Recommendations

Introduction

Background of evaluation

Process Description

Associated Equipment

Process Flow Diagram

Process Assessment

Methodology

Material Balance

Unusual Occurrences

Option Summary and Analysis

Option Description and rank

Upstream/Downstream impacts

Material usage

Anticipated reduction

Estimated costs

Estimated benefits

Feasibility

Waste streams affected

Conclusion

Concluding evaluation

Option analysis decisions

Concerns

Options already. implemented

Lessons learned

Recommendations

Future work

New Equipment

Implementation strategies

\section{Completed}

$x$

$x$

$\mathbf{x}$

$\mathrm{X}$

$x$

$x$

$\mathrm{x}$

$\mathrm{X}$

$x$ 
Appendix D

PPOA Worksheets

for TSCA Site Operations 
D-3

Wortesseer

Level III

Revision No.: 0

Revision Date:9/08/95

\section{Pollution Prevention Opportunity Assessment PPOA Team}

PPOA Title: TSCA Incinerator

PPOA ID Code: . TSCA Site Operations

\begin{tabular}{lll} 
Name & Job Classification & Phone \\
\hline \hline James T. Nelson & Sr. Environmental Engineer & $615 / 483-0666$ \\
Wiliam Nicholas & Sr. Environmental Engineer & $615 / 483-0666$ \\
Steven J. Kirslis & Environmental Engineer & $615 / 483-0666$ \\
Marshall A. Eaves & Project Engineer & $615 / 576-3974$ \\
James E. Dunn, Jr. & $\begin{array}{l}\text { Engineering and.Analysis Department } \\
\text { Manager }\end{array}$ & $615 / 241-5751$ \\
W. Gerald Melton & $\begin{array}{l}\text { Manager-Waste and Residuals Management } \\
\text { Program }\end{array}$ & $615 / 241-2100$ \\
Fidel Perez & TSCA Incinerator Division Director & $615 / 576-5257$
\end{tabular}




\section{Pollution Prevention Opportunity Assessment}

\section{-Process Description}

PPOA Title: TSCA Incinerator

PPOA ID Code: TSCA Site Operations

Process Location: TSCA Incinerator - K-25 Site

Process Description: This waste stream includes materials contaminated from normal facility operations, spill response, and maintenance activities.

\section{Description of Major Product(s) of Process:}

TSCA trash, LLW metals, solid and wood 


\section{Pollution Prevention Opportunity Assessment}

\section{Process Flow Diagram}

PPOA Title or PPOA ID Code(s): TSCA Site Operations

Inputs:

LLW Wood

LLW Metals

LLW Solids

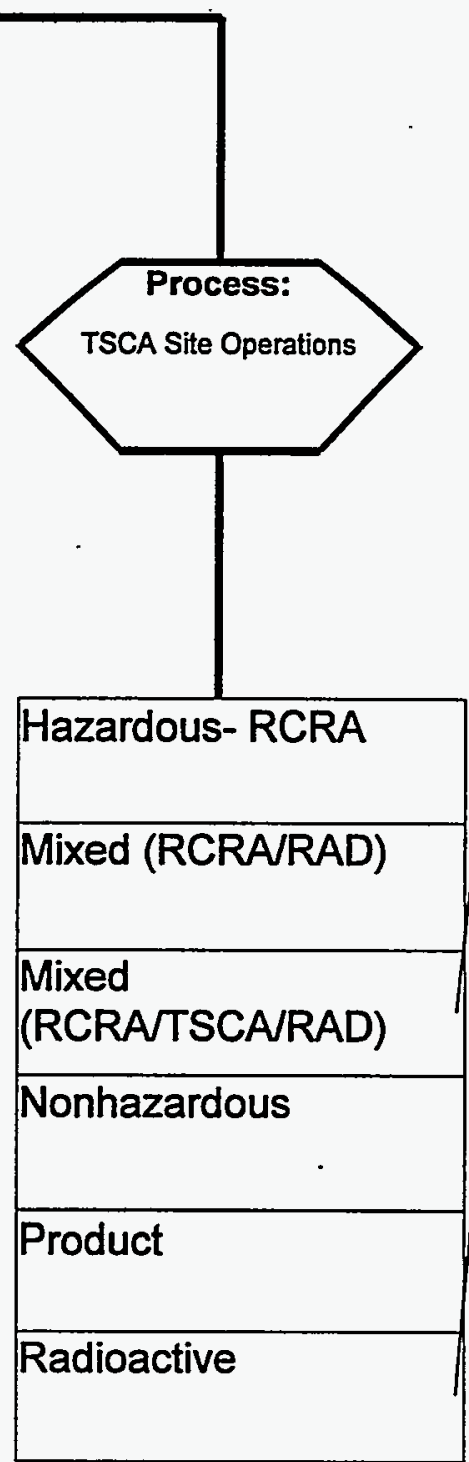

\begin{tabular}{|c|c|l|}
\hline MX1 & Solid & $\begin{array}{l}\text { TSCA Trash, solids- } \\
\text { maint. operations }\end{array}$ \\
\hline RD1 & Solid & LLW Wood \\
\hline RD1 & Solid & LLW Solids \\
\hline RD1 & Solid & LLW Metals \\
\hline
\end{tabular}




\section{Pollution Prevention Opportunity Assessment}

\section{Material Balance Summary}

PPOA Title or PPOA ID Code(s): TSCA Site Operations

Output Quantity Units: KG

\begin{tabular}{|c|c|c|c|}
\hline \multirow[t]{2}{*}{ Material Description } & \multirow{2}{*}{$\begin{array}{c}\text { Total } \\
\text { Output }\end{array}$} & $\begin{array}{l}\text { Stream } \\
\text { ID Code }\end{array}$ & $\begin{array}{l}\text { Stream } \\
\text { ID Code }\end{array}$ \\
\hline & & MXI & RDI \\
\hline TSCA Trash, solids--maint. operations & 25,237 & 25,237 & 0 \\
\hline LLW Solids & 496 & 0 & 496 \\
\hline LLW Metals & $\overline{8,736}$ & $\overline{0}$ & $\overline{8,736}$ \\
\hline LLW Wood & $\overline{14,734}$ & $\overline{0}$ & $14,734(1)$ \\
\hline Totals/Subtotals & 49,203 & $\cdot 25,237$ & 23,966 \\
\hline
\end{tabular}




\section{Pollution Prevention Opportunity Assessment Input Material and Output Disposal Cost}

PPOA Title or PPOA ID Code: TSCA Site Operations Input Material Cost:

\begin{tabular}{|l|r|r|r|}
\hline \multicolumn{1}{|c|}{ Material } & Quantity (kg) & Cost Per Unit & \multicolumn{1}{c|}{ Annual Cost } \\
\hline LLW Solids & 0.00 & 0 & $\$ 0.00$ \\
\hline LLW Metals & 0.00 & 0 & $\$ 0.00$ \\
\hline LLWWood & 0.00 & 0 & $\$ 0.00$ \\
\hline \multicolumn{1}{|c|}{ Total/Subtotal } & 0.00 & & $\$ 0.00$ \\
\hline
\end{tabular}

Waste Disposal Cost:

\begin{tabular}{|c|c|c|c|c|}
\hline Material/Waste Stream & $\begin{array}{c}\text { Stream } \\
\text { Code }\end{array}$ & Qty (kg) & Cost Per Unit & Annual Cost \\
\hline LLW Solids & RD1 & 496 & $\overline{6}$ & $\$ 2,976.00$ \\
\hline LLW Metals & RD1 & 8,736 & 6 & $\$ 52,416.00$ \\
\hline LLW Wood & RD1 & 14,734 & 6 & $\$ 88,404.00$ \\
\hline TSCA Trash, solids--maint. operations & $\overline{M X 1}$ & 25,237 & 6 & $\$ 151,422.00$ \\
\hline . Total/Subtotal & & 49,203 & & $\$ 295,218.00$ \\
\hline
\end{tabular}




\section{Pollution Prevention Opportunity Assessment Option Generation}

PPOA Title or PPOA ID Code: TSCA Site Operations

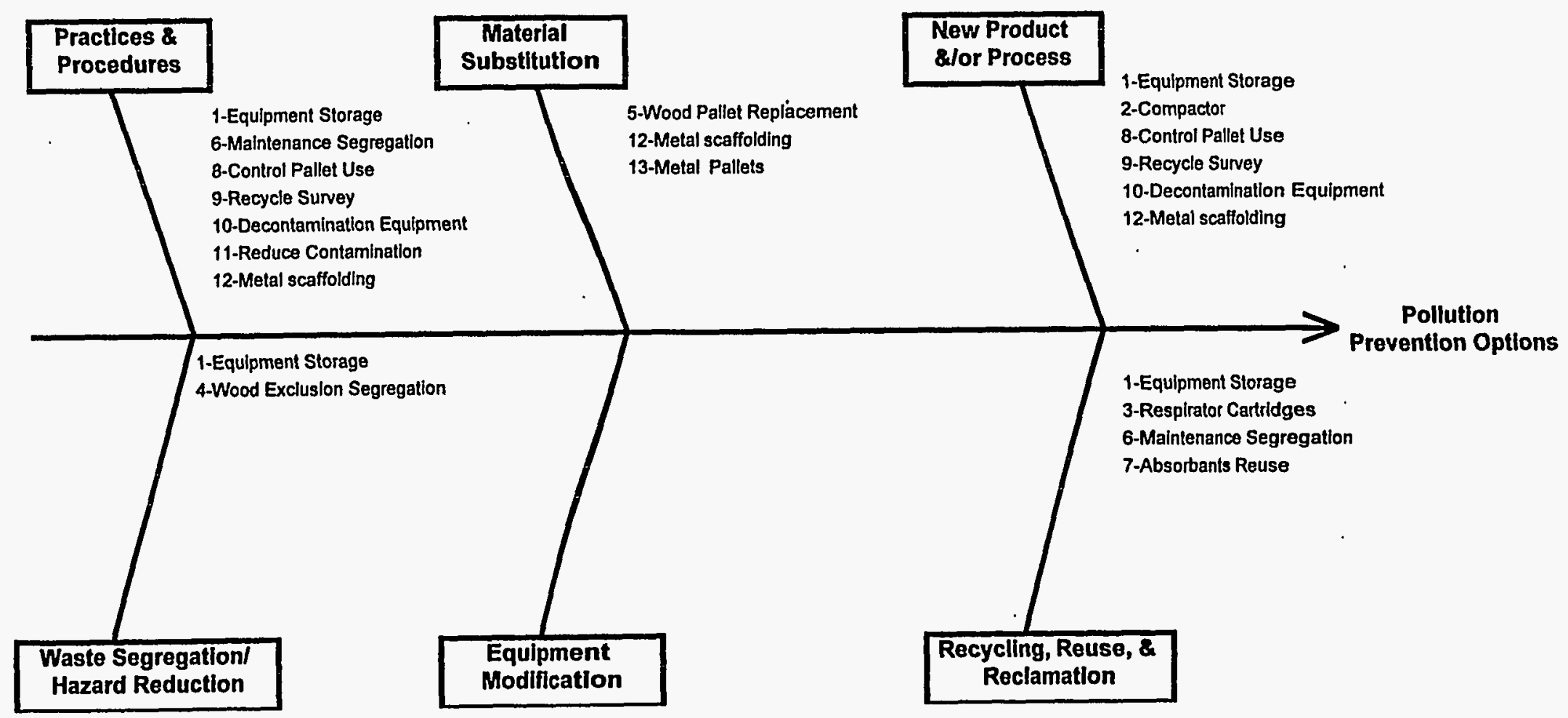




\section{Pollution Prevention Opportunity Assessment Option Description}

PPOA Title or PPOA ID Code: TSCA Site Operations

Option Name and Description

(Include input materials, products affected, and anticipated reduction quantity.)

Option No. 1 : Sort usable equipment and place in containers for future use. Coordinate maintenance efforts to save usable equipment such as pump wet ends.

\begin{tabular}{|c|c|c|}
\hline Practices \& Procedure & 凶 & $\begin{array}{c}\text { Consider Option Further } \otimes \text { Yes } \\
\text { Waste Segregation/Hazardous Reduction }\end{array}$ \\
\hline Material Substitution & $\square$ & Equipment Modification \\
\hline New Product \&/or Process & 凶 & Recycle, Reuse, Reclamation \\
\hline
\end{tabular}

Option No. 2 : Compactor - install trash compactor to reduce solid waste volume and mass of containerized waste to be disposed.
Consider Option Further $\bigotimes$ Yes $\square$ No
Practices \& Procedure
Waste Segregation/Hazardous Reduction
Material Substitution
Equipment Modification
New Product \&/or Process $\bigotimes$
Recycle, Reuse, Reclamation

Option No. 3 : Reuse of respirator cartridges- clean and reuse cartridges (consider PCB contamination). Not considered operationally feasible.

Consider Option Further $\square$ Yes $\quad$ No

Practices \& Procedure

Material Substitution

New Product \&/or Process
Waste Segregation/Hazardous Reduction

Equipment Modification

Recycle, Reuse, Reclamation $\otimes$ 


\section{Pollution Prevention Opportunity Assessment Option Description}

PPOA Title or PPOA ID Code: TSCA Site Operations

Option Name and Description

(Include input materials, products affected, and anticipated reduction quantity.)

Option No. 4 : Wood Exclusion Segregation- exclude wood/pallets, scaffolding, etc. from the contaminated zone. Remove packaging materials. Pricing considered in options 5,12,13, and 14 .

\begin{tabular}{|c|c|c|}
\hline Practices \& Procedure & $\square$ & Waste Segregation/Hazardous Reduction \\
\hline Material Substitution & $\square$ & Equipment Modification \\
\hline New Product \&/or Process & $\square$ & Recycle, Reuse, Reclamation \\
\hline
\end{tabular}

Option No. 5 : Pallets- use plastic pallets instead of wood. Make transfer upon entering the contaminated zone.

Consider Option Further $\square$ Yes $\square$ No Consider Option Further $\quad$ Yes $\square$ No

Practices \& Procedure

Material Substitution 囚

-New Product \&/or Process
Waste Segregation/Hazardous Reduction

Equipment Modification

Recycle, Reuse, Reclamation

Option No. 6 : Coordinate maintenance efforts to save reusable equipment, such as pump seal replacement. Pricing considered in option 1.

Practices \& Procedure 囚

Material Substitution

New Product \&/or Process

\author{
Consider Option Further $\square$ Yes $\square_{\text {No }}$ \\ Waste Segregation/Hazardous Reduction \\ Equipment Modification \\ Recycle, Reuse, Reclamation $\square$
}




\section{Pollution Prevention Opportunity Assessment}

\section{Option Description}

\section{PPOA Title or PPOA ID Code: TSCA Site Operations}

Option Name and Description

(Include input materials, products affected, and anticipated reduction quantity.)

Option No. $7 \quad$ : Rags/diapers- clean and reuse rags and diapers within the contaminated zone. Not considered good industrial hygiene practice.

$$
\text { Consider Option Further } \square \text { Yes } \square \text { No }
$$

Practices \& Procedure

Material Substitution

New Product \&/or Process
Waste Segregation/Hazardous Reduction

Equipment Modification

Recycle, Reuse, Reclamation $\square$

Option No. 8 : Use of control pallets- use plastic wrap when using process pallets in clean area from empty drum pickup. Not considered for recommendation.

Consider Option Further $\square$ Yes $\quad$ No

Practices \& Procedure 区

Material Substitution

New Product \&/or Process $\bigotimes$
Waste Segregation/Hazardous Reduction

Equipment Modification

Recycle, Reuse, Reclamation

Option No. $9 \quad$ : PPE, G-Flex, and plastics shredder- reduce plastic to powder, since powder sampling can be assumed representative. Use processed powder for B-25 waterproofing, secondary containment building materials, and loose item contamination bags. Operation success is doubtful.

$$
\text { Consider Option Further } \square \text { Yes } \square_{\text {No }}
$$

Practices \& Procedure 囚

Material Substitution

New Product \&/or Process $\bigotimes$
Waste Segregation/Hazardous Reduction

Equipment Modification

Recycle, Reuse, Reclamation 


\section{Pollution Prevention Opportunity Assessment Option Description}

PPOA Title or PPOA ID Code: TSCA Site Operations

Option Name and Description

(Include input materials, products affected, and anticipated reduction quantity.)

Option No. 10 : Decontaminate Equipment -- (pallets, scaffolds, shields, and container). Benefits allow (1) extended use of products inside and out of the control zone and (2) reduced contamination. Not priced; included in Option 12.

$\begin{array}{llrl} & & \text { Consider Option Further } \quad \square \text { Yes } \quad \text { No } \\ \text { Practices \& Procedure } & \bigotimes & \text { Waste Segregation/Hazardous Reduction } & \square \\ \text { Material Substitution } & \square & \text { Equipment Modification } & \square \\ \text { New Product \&/or Process } & \bigotimes & \text { Recycle, Reuse, Reclamation } & \square\end{array}$

Option No. 11 : Extended transition zone- in courtyard, establish transition zone to transfer material from clean only carriers to process carriers. This will reduce introduction of packaging materials into control zones. Current practice addresses this.

$\begin{array}{lrrr} & & \text { Consider Option Further } \quad \square \text { Yes } \quad \square \text { No } \\ \text { Practices \& Procedure } & \bigotimes & \text { Waste Segregation/Hazardous Reduction } \quad \square \\ \text { Material Substitution } & \square & \text { Equipment Modification } & \square \\ \text { New Product \&/or Process } & \square & \text { Recycle, Reuse, Reclamation } & \square\end{array}$

Option No. 12 : Metal scaffolding- purchase metal scaffolding instead of wood. Can be purchased and constructed so as to be decontaminated and assembled as needed.

Practices \& Procedure $\quad$ Q

Material Substitution $\quad \square$

New Product \&/or Process
Consider Option Further $\quad \square$ Yes $\square$ No Waste Segregation/Hazardous Reduction

Equipment Modification Recycle, Reuse, Reclamation 


\section{Pollution Prevention Opportunity Assessment Option Description}

PPOA Title or PPOA ID Code: TSCA Site Operations

Option Name and Description

(Include input materials, products-affected, and anticipated reduction quantity.)

Option No. 13 : Metal pallets -- replace wooden pallets with metal pallets.

Consider Option Further $\otimes$ Yes $\square$ No

Practices \& Procedure Waste Segregation/Hazardous Reduction

Material Substitution $\quad$ \ Equipment Modification

New Product \&/or Process Recycle, Reuse, Reclamation

Option No. 14 : Rent metal scaffolding. Supplier will deliver and decontaminate.

$$
\text { Consider Option Further } \quad \text { Yes } \square \text { No }
$$

Practices \& Procedure $\quad$ Waste Segregation/Hazardous Reduction

Material Substitution

New Product \&/or Process
Equipment Modification

Recycle, Reuse, Reclamation 


\title{
Pollution Prevention Opportunity Assessment
}

\author{
Options Cost Evaluation
}

\section{PPOA Title or PPOA ID Code(s): TSCA Site Operations}

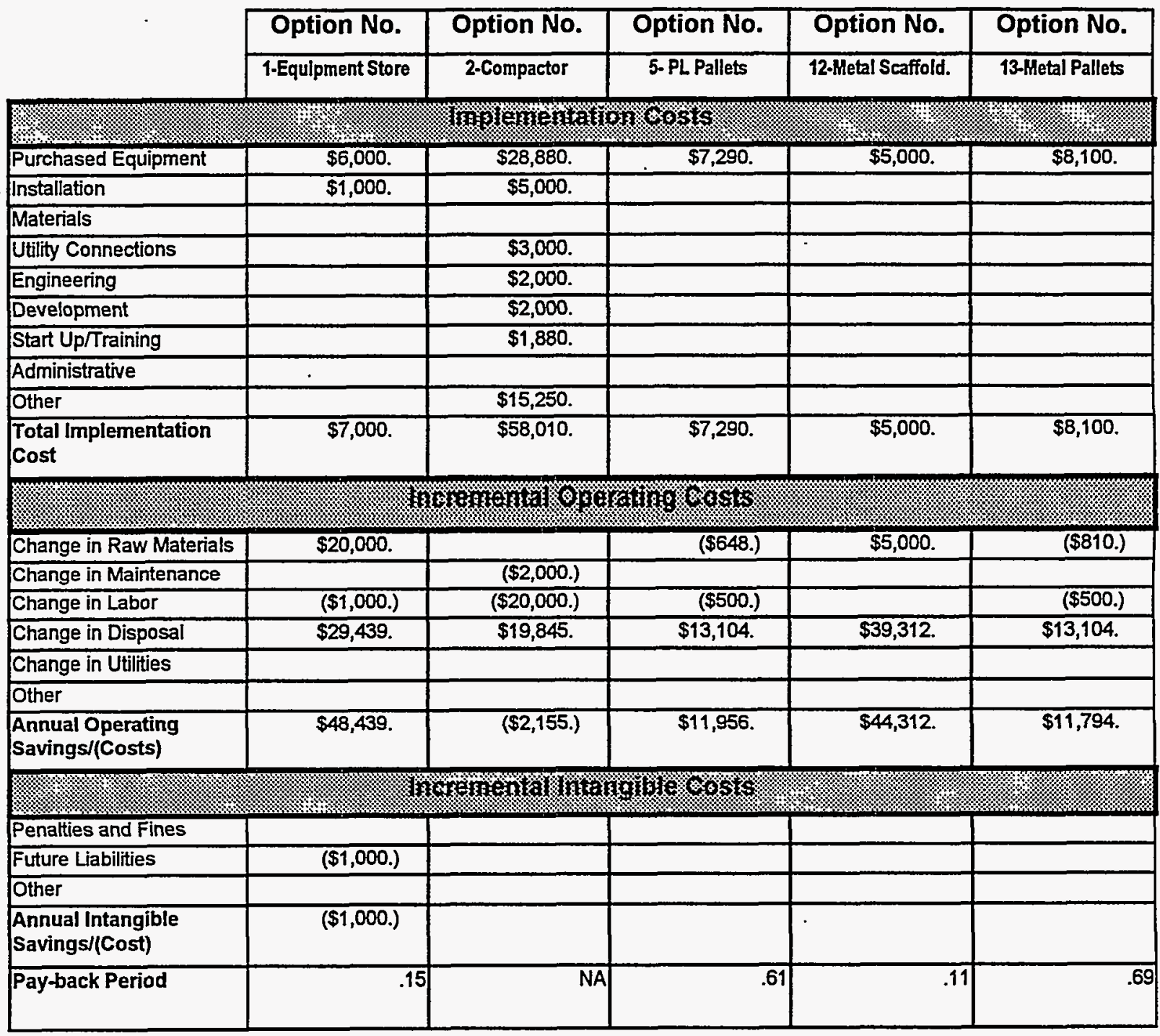




\begin{tabular}{|c|c|}
\hline \multirow[t]{5}{*}{000} & 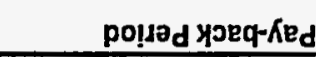 \\
\hline & 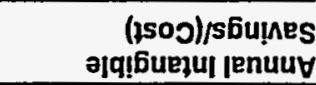 \\
\hline & ग2410 \\
\hline & 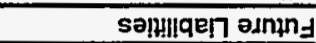 \\
\hline & sau!y pue senjeuad \\
\hline \multicolumn{2}{|c|}{ 多 } \\
\hline ZIE'gZ\$ & $\begin{array}{l}\text { (sisoj)/sbugnes } \\
\text { 6unpedodo jenuut }\end{array}$ \\
\hline \multirow[t]{2}{*}{$\left(000^{\circ} \angle S\right)$} & dayto \\
\hline & 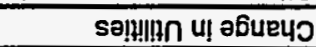 \\
\hline 乙டع'6E\$ & |esods!a u| abิueu० \\
\hline \multirow[t]{3}{*}{$\left(000^{\prime}+\$\right)$} & Joqe7 u! abueपว \\
\hline & 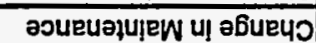 \\
\hline & 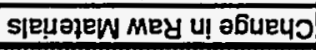 \\
\hline \multicolumn{2}{|c|}{ 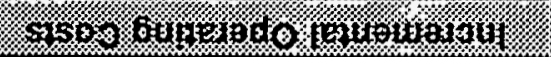 } \\
\hline & 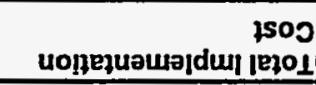 \\
\hline & da410 \\
\hline & 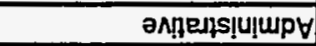 \\
\hline & Gu!u!edydก भels \\
\hline & 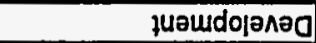 \\
\hline & 6นบขอลน!6u \\
\hline & suoppouuos Ku!!!n \\
\hline & S|리러 \\
\hline & 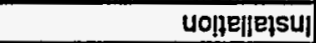 \\
\hline & quaudu!nby paseyound \\
\hline \multicolumn{2}{|c|}{ 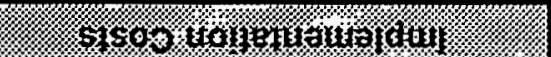 } \\
\hline 'Ploypess zuayth & \\
\hline -ON uO!̨do & \\
\hline
\end{tabular}

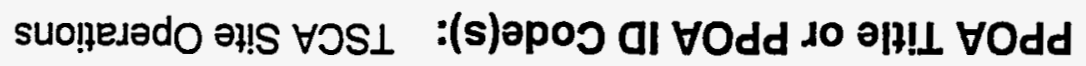
uo!̣en|е^ヨ ısoว suo!̣do

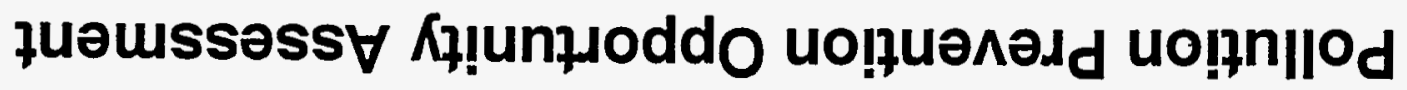
$\zeta$ to $\zeta$ ә6е d \$6/8/6 :ajeQ uolsinay III 1әләך

$\tau$ :ON UOIS!nay 


\section{Pollution Prevention Opportunity Assessment \\ Weighted Sums Options Evaluation}

PPOA Title or PPOA ID Code(s): TSCA Site Operations

\begin{tabular}{|l|r|r|r|r|r|r|r|r|r|}
\hline \multicolumn{1}{|c|}{ Criteria } & \multicolumn{2}{c|}{ Optlon 1 } & \multicolumn{2}{c|}{ Option 2 } & \multicolumn{2}{c|}{ Option 5 } & \multicolumn{2}{|c|}{ Optlon 12 } \\
\hline
\end{tabular}




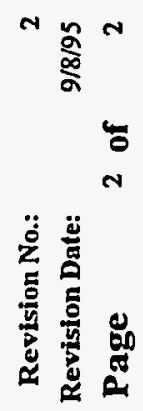

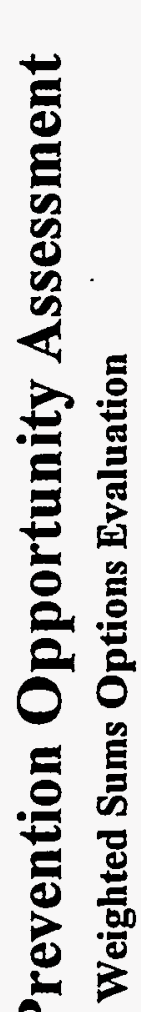

包

.气

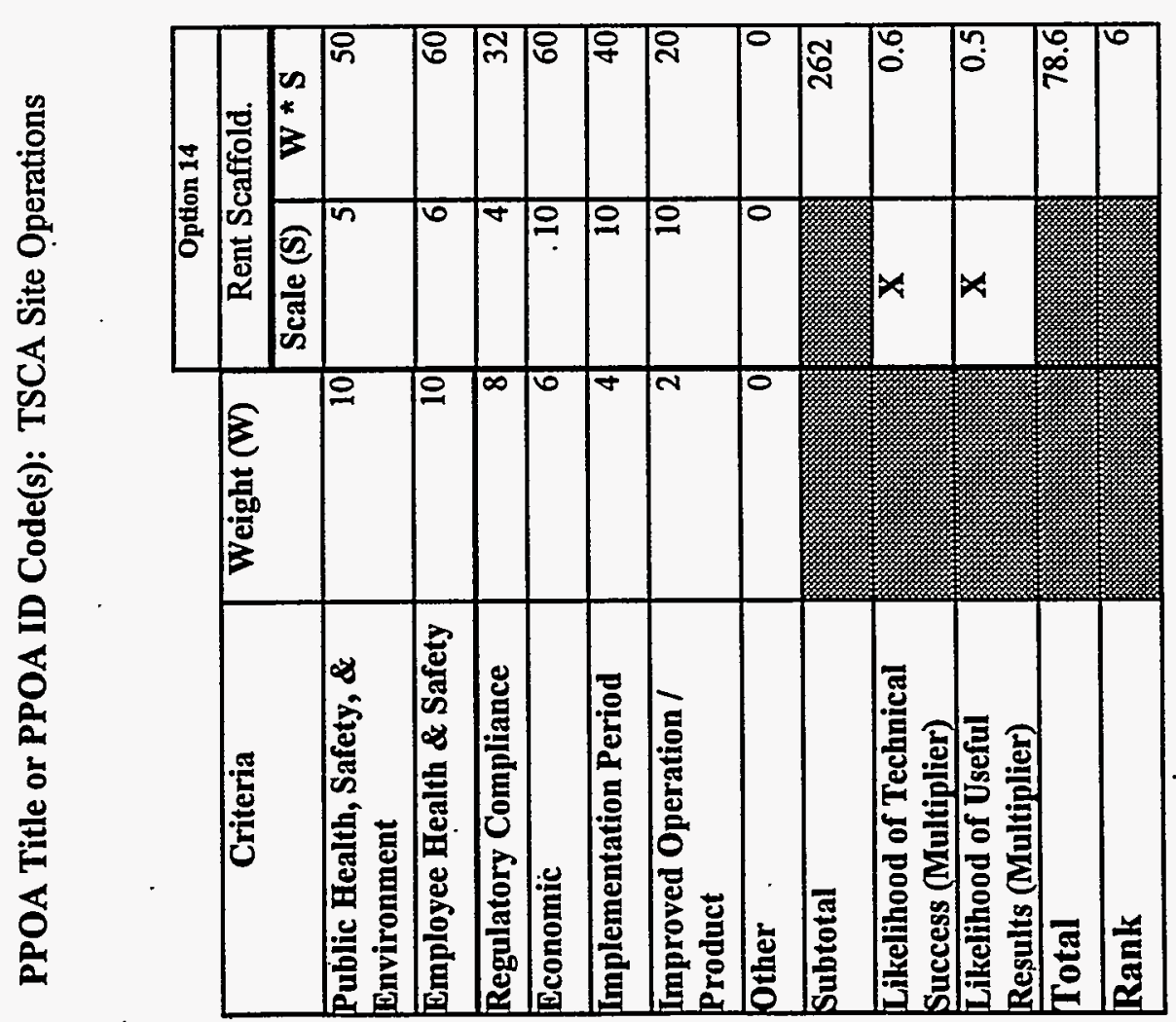

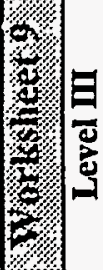




\title{
Pollution Prevention Opportunity Assessment Final Report Check Sheet
}

\author{
PPOA Title: TSCA Incinerator \\ PPOA ID Code: TSCA Site Operations
}

\section{Requirement}

Title Page

PPOA Title

PPOA Id Code

Team Members

Issure date/revision date/revision no.

Executive Summary

Process Description

Process Assessment

Option Summary and analysis

Conclusions

Recommendations

Introduction

Background of evaluation

Process Description

Associated Equipment

Process Flow Diagram

Process Assessment

Methodology

Material Balance

Unusual Occurrences

Option Summary and Analysis

Option Description and rank

Upstream/Downstream impacts

Material usage

Anticipated reduction

Estimated costs

Estimated benefits

Feasibility

Waste streams affected

Conclusion

Concluding evaluation

Option analysis decisions

Concerns

Options already implemented

Lessons learned

Recommendations

Future work

New Equipment

Implementation strategies

\section{Completed}

$\mathrm{x}$

$x$

$x$

$\mathrm{X}$

$x$

$\mathbf{x}$

X

$\mathbf{x}$

$x$ 
Appendix E

Cost Estimate and Calculations 
-

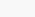

$$
\text { , }
$$




\section{CAMERA COOLING WATER TSCA-PPOA COST ESTIMATE SUMMARY}

LMES Maintenance

Escalation at $5 \%$

SUBTOTAL

$\$ 21,000$

Assumptions:

- Work to be performed by TSCA Incinerator site maintenance personnel.

- Very preliminary "order of magnitude" estimate, because no detail design was available. Based on preliminary process flow sketch.

- Construction performed during shutdown-no overtime included.

- Level D PPE required-no respirators, etc.

- A minimum 4-week incinerator shutdown would be required to implement the project, perhaps during the annual TSCA Incinerator shutdown each October. 
JOB NAME Camera Cooling Water/TSCA PPOA

JOB NO.

$1001-516$

BUILDING

CONST. BY LMES Maintenance

DATE $\underline{6 / 30 / 95}$

\begin{tabular}{|c|c|c|c|c|c|c|c|c|c|}
\hline $\begin{array}{l}\text { ITEM } \\
\text { NO. }\end{array}$ & 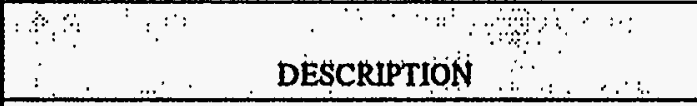 & QUAX & unit & $\begin{array}{l}\text { MATERAAL } \\
\text { PRACE }\end{array}$ & $\begin{array}{l}\text { MATERAAL } \\
\text { TOTAL }\end{array}$ & $\begin{array}{l}\text { Utivit } \\
\text { MHiRs } \\
\end{array}$ & Mings & $\begin{array}{l}\text { CRAFT } \\
\text { RATE } \\
\end{array}$ & $\begin{array}{l}\text { LAB̈OÄ } \\
\text { TOTAL }\end{array}$ \\
\hline 1 & Modify existing cameras to provide new connections & 2 & Each & 200.00 & 400 & & 16 & & \\
\hline 2 & New 1-in. galvanized pipe with fittings & 40 & LF & 5.00 & 200 & & 24 & & \\
\hline 3 & New valves & 2 & Each & 300.00 & 600 & & 6 & & \\
\hline 4 & Pipe insulation & 40 & LF & 2.50 & 100 & & 8 & & \\
\hline \multirow[t]{2}{*}{5} & Testing of piping system & 1 & Lot & 100.00 & 100 & & 12 & & \\
\hline & Subtotal & & & & $\$ 1,400$ & & 66 & 51.00 & $\$ 3,366$ \\
\hline 6 & Support craft to above (20\%) & 1 & Lot & & & & & & 673 \\
\hline 7 & Testing, tags, identification & 1 & Lot & & 100 & & $8 \mathrm{hrs}$ & 51.00 & 408 \\
\hline 8 & PPE @ \$3.00/hr. & 1 & Lot & & 450 & & 24 hrs & 51.00 & 1,224 \\
\hline \multirow[t]{2}{*}{9} & HP/IH & 1 & Lot & & & & $12 \mathrm{hrs}$ & 51.00 & 612 \\
\hline & Subtotal & & & & $\$ 1,950$ & & & & $\$ 6,283$ \\
\hline
\end{tabular}

Summary:

Material

Labor

$\$ 1,950$

Subtotal

LMES K-25 Overhead @ 38\%

6,283

$\$ 8,233$

Subtotal

3,129

$\$ 11,362 \approx \$ 12,000$ 


\section{E-5 \\ QUENCH REROUTING \\ TSCA-PPOA \\ COST ESTIMATE SUMMARY}

LMES Maintenance

$\$ 38,000$

LMES - Title I \& II Engineering

$(80 \mathrm{hrs} \times \$ 80.00 / \mathrm{hr})$

LMES - Title III Engineering

$(40 \mathrm{hrs} \times \$ 70.00 / \mathrm{hr})$

LMES - Construction Support/Project Management

$(90 \mathrm{hrs} \times \$ 70.00 / \mathrm{hr})$

SUBTOTAL

$\$ 53,500$

Contingency at $30 \%$

$\$ 16,000$

SUBTOTAL

$\$ 69,500$

Escalation at 5\%

$\$ 3,500$

PROJECT TOTAL

$\$ 73,000$

Assumptions:

- Work to be performed by TSCA site maintenance personnel.

- Very preliminary "order of magnitude" estimate, because no detail design was available. Based on preliminary process flow sketch.

- Construction performed during shutdown-no overtime included.

- Level D PPE required-no respirators, etc.

- Estimate does not include costs associated with modifying the RCRA Part B permit.

- A minimum 4-week incinerator shutdown would be required to implement project, perhaps during the annual TSCA Incinerator shutdown each October. 
JOB NAME Quench Rerouting/TSCA PPOA

JOB NO.

$1001-516$

BUILDING

CONST. BY LMES Maintenance

DATE $\underline{6 / 30 / 95}$

\begin{tabular}{|c|c|c|c|c|c|c|c|c|c|}
\hline $\begin{array}{l}\text { TTEM } \\
\text { NO }\end{array}$ & DESCRTPTION & QUAN & onix & $\begin{array}{l}\text { MATERtAL } \\
\text { ARICE }\end{array}$ & $\begin{array}{l}\text { MATERIAL } \\
\text { TOTAL }\end{array}$ & $\begin{array}{l}\text { UNivit } \\
\text { MitiRs }\end{array}$ & MHRs & $\begin{array}{l}\text { CCRAFT } \\
\text { RATE }\end{array}$ & $\begin{array}{l}\text { ABBOR } \\
\text { TOTÁ }\end{array}$ \\
\hline 1 & Remove existing piping & 1 & Lot & 100 & 100 & & 16 & & \\
\hline 2 & Modify existing piping to provide new connections & 1 & Lot & 150 & 150 & & 16 & & \\
\hline 3 & New 3-in. S.S. pipe with fittings & 60 & LF & 30 & 1,800 & & 120 & & \\
\hline 4 & New valve & 1 & Each & 650 & 650 & & 4 & & \\
\hline 5 & New flow meter & 1 & Each & 5,000 & 5,000 & & 12 & & \\
\hline 6. & Electrical/instrumentation & 1 & Lot & $\cdot 500$ & 500 & & 24 & & \\
\hline 7 & Weld Inspection & 1 & Lot & 100 & 100 & & 16 & & \\
\hline 8 & Testing of piping systems & 1 & Lot & 100 & 100 & & 16 & & \\
\hline 9 & Scaffolding & 1 & Lot & 400 & 400 & & 16 & & \\
\hline & Subtotal & & & & $\$ 8,800$ & & 240 & 51.00 & $\$ 12,240$ \\
\hline 10 & Support craft to above (20\%) & 1 & Lot & & & & & & 2,450 \\
\hline 11 & Tags, identification & 1 & Lot & 100 & 100 & & $16 \mathrm{hrs}$ & 51.00 & 800 \\
\hline 12 & PPE at $3.00 / \mathrm{hr}$ & 1 & Lot & 500 & 500 & & 40 hrs & 51.00 & 2,040 \\
\hline 13 & HP/IH & 1 & Lot & & & & $16 \mathrm{hrs}$ & 51.00 & 820 \\
\hline & Subtotal & & & & $\$ 9,400$ & & & & $\$ 18,350$ \\
\hline
\end{tabular}

Summary:

Material

$\$ 9,400$

Labor

18,350

Subtotal

$\$ 27,750$

LMES K-25 Overhead @ 38\%

10,545

Subtotal

$\$ 38,295 \approx \$ 38,000$ 
A/E - Title I \& II Engineering

$(480 \mathrm{hrs} \times \$ 65 / \mathrm{hr})$

LMES - Title III Engineering

LMES - Construction Support/Project Management

$(500 \mathrm{hrs} \times 70.00 / \mathrm{hr})$

Contingency at $20 \%$

SUBTOTAL

Escalation at $5 \%$

SUBTOTAL

$\$ 320,000$

$\$ 16,000$

PROJECT TOTAL

Assumptions:

- Capital Funding -no plant overhead included.

- Very preliminary "order of magnitude" estimate, because no detail design was available. Based on preliminary process flow sketch.

- Construction performed during shutdown-no overtime included.

- Level D PPE required-no respirators, etc.

- Estimate does not include costs associated with modifying the RCRA Part B permit.

- A minimum four 4-week incinerator shutdown would be required to implement project, perhaps during the annual TSCA Incinerator shutdown each October.

- Work to be done in non-contaminated area. 


\begin{tabular}{|c|c|c|c|c|c|c|c|c|c|}
\hline $000^{6} I$ & $00^{\circ} 0 S$ & $0 Z$ & & & & 107 & l & HI/dH & Iz \\
\hline $0 t Z^{\prime} I$ & $00^{\circ}$ IE & ob & & $00 z^{\prime} z$ & & 107 & I & Iq/00'E Idd & 02 \\
\hline $0+Z^{t} I$ & $00^{\circ} I E$ & ot & & 009 & & 107 & I & 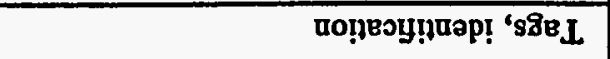 & $6 I$ \\
\hline $0 Z L^{\prime} \mathfrak{E}$ & $00^{\circ} I \varepsilon$ & OZI & & 009 & & 107 & $\mathfrak{I}$ & səD!AJas KreIodura $L$ & $8 I$ \\
\hline $0 t t^{\prime} t$ & & & & & & 107 & $\mathbf{I}$ & 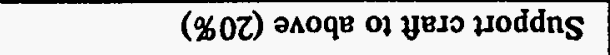 & $\angle I$ \\
\hline \multirow[t]{17}{*}{$00 z^{6} z z$} & & $9 I L$ & & $028^{4} 69$ & & & & jopotqns & \\
\hline & & 9l & & $00 t$ & $0 S 2$ & $\mathbf{d T}$ & OLI & uo!̣e[nsul əd!d & 91 \\
\hline & & $b \tau$ & & $000^{\prime} 1$ & $00^{\circ} 000^{4} 1$ & 207 & I & 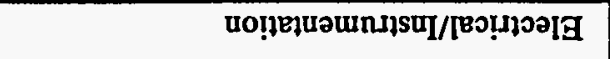 & SI \\
\hline & & 8 & & 008 & $00^{\circ} 008$ & प०ё & I & dunnd $_{d}$ & tI \\
\hline & & & & $008^{\circ} t$ & 00.008 & sא́R & 9 & 8u!peয়8 sof juourd!̣nbg & $\varepsilon l$ \\
\hline & & $0 t$ & & 002 & 00.002 & 107 & I & surels א́s guṭd!̣ jsa $\mathrm{J}$ & $Z I$ \\
\hline & & 86 & & $00 \varepsilon$ & $00^{\circ} 00 \varepsilon$ & 207 & I & uo!̣oədsu! plaM & II \\
\hline & & 9I & & $008^{\prime} \tau$ & $00^{\circ} 00 \mathrm{~L}$ & प०в马 & $t$ & $\operatorname{san}[E \Lambda$ & ol \\
\hline & & $00 \mathrm{I}$ & & $00 L^{\prime} r$ & $00^{\circ} s b$ & $\Delta T$ & 09 & 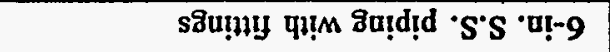 & 6 \\
\hline & & 08 & & ozt'Z & $00 \cdot 22$ & $A T$ & OII & 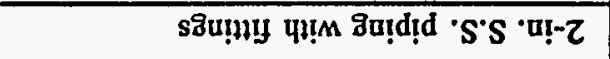 & 8 \\
\hline & & 79 & & $000^{\prime} 0 S$ & $00^{\circ} 000^{\prime} 0 \mathrm{~S}$ & q०Bg & $\mathfrak{I}$ & গUe' $\cdot S^{\circ} S$ & $L$ \\
\hline & & t9 & & $00 s$ & 00.005 & 101 & $\mathfrak{I}$ & 8u!d!̣d 8u!̣s!xə yномәу & 9 \\
\hline & & 69 & & $00 Z^{\prime} \varepsilon$ & $00^{\circ} 00 t$ & Xo & 8 & 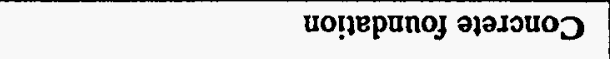 & $s$ \\
\hline & & 79 & & & & 107 & $\mathfrak{I}$ & 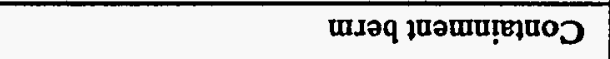 & $b$ \\
\hline & & $z \varepsilon$ & & $00 S$ & $00^{\circ} \mathrm{S}$ & $\$ T$ & 00I & 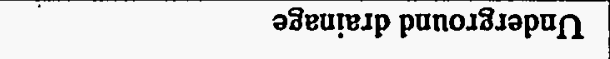 & $\varepsilon$ \\
\hline & & $z \varepsilon$ & & 002 & $00^{\circ} 0 \mathrm{I}$ & noL & $0 z$ & sqв[S sәpun әuо)S & $\tau$ \\
\hline & & $\forall 9$ & & & & 101 & I & पо!!вАвอХด & I \\
\hline $\begin{array}{l}\text { TV101 } \\
\text { yogyt }\end{array}$ & arvis & syin & sxikn & $\begin{array}{l}\text { TVLOL } \\
\text { TVISTHW }\end{array}$ & 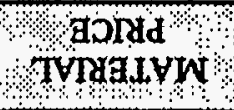 & IINO & NYחD & ২ি NoL & ON \\
\hline
\end{tabular}




\begin{tabular}{|c|c|c|c|c|c|c|c|c|c|}
\hline TTEM & 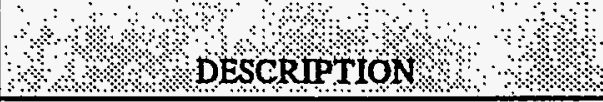 & Qüâ: & UniT: & $\begin{array}{l}\text { MATERIAL } \\
\text { PRTCE }\end{array}$ & $\begin{array}{l}\text { MATERIAL } \\
\text { TOTALS }\end{array}$ & UMNIT & MiHRs & ( $\mathrm{CRAFT}$ & \%? 1 TOBOR \\
\hline \multirow[t]{6}{*}{22} & Productivity Loss - Rad Area, Travel & 1 & Lot & & & & 120 & 31.00 & 3,720 \\
\hline & Subtotal & & & & 73,220 & & & & 37,560 \\
\hline & Shop support/misc. 3.2\%/6.3\% of labor & & & & 2,340 & & & & 2,400 \\
\hline & Cleanup at $6 \%$ & & & & & & & & 2,300 \\
\hline & Vehicle charge & & & & 1,200 & & & $\div$ & \\
\hline & Subtotal & $\therefore$ & & & 76,760 & & & & 42,260 \\
\hline
\end{tabular}

$\begin{array}{lr}\text { Summary: } & \\ \text { Material } & \$ 77,000 \\ \text { Labor } & 43,000 \\ \text { Subtotal } & \$ 120,000 \\ \text { Administrative Support } & 30,000 \\ \text { Subtotal } & \$ 150,000 \\ \text { Indirects @ 24\% } & 36,000 \\ \text { Total MKF - Direct Hire } & \$ 186,000\end{array}$




\section{Kiln Operations Cost Estimates}

\section{Option No. 1-Kiln Temperature Reduction}

Change in Raw Materials

$1994+1995$ brick waste total $=44,000 \mathrm{~kg}$

Assume annual brick waste $=44,000 \mathrm{~kg} \div 2=22,00 \mathrm{~kg} /$ year

A reduction in the operating temperature is assumed to extend the brick life one year. The new annual brick waste $=44,000 / 3=15,000 \mathrm{~kg} /$ year. The brick waste reduction from this option is: $22,000-15,000=7,000 \mathrm{~kg} /$ year.

The material cost for rebricking the kiln in 1995 was $\$ 20,071$. The brick removed and replaced weighed $32,000 \mathrm{~kg}$ and the estimated brick cost is: $\frac{\$ 20,071}{32,000 \mathrm{~kg}}=\$ 0.62 / \mathrm{kg}$

The material cost for $7,000 \mathrm{~kg}$ is: $\$ 7,000 \mathrm{~kg} \times \frac{\$ 0.62}{\mathrm{~kg}}=\$ 4,390$

\section{Change in Maintenance}

The maintenance cost for rebricking the kiln in 1995 was $\$ 226,575$. Assuming a one-year extension in the brick life, the labor cost per year is: $\frac{\$ 226,575}{3 \text { years }}=\$ 75,525 /$ year

\section{Change in Disposal}

As stated above, the expected reduction in brick waste is $7,000 \mathrm{~kg} /$ year. Based on CY 1994 data, a drum of bricks weighs about $238 \mathrm{~kg}$. Disposal cost is assumed to be $\$ 441 / \mathrm{drum}$.

Disposal savings is:

$$
\frac{7000 \mathrm{~kg}}{\text { year }} \times \frac{d r u m}{238 \mathrm{~kg}} \times \frac{\$ 441}{d r u m}=\$ 12,970 / \mathrm{yr}
$$

\section{Change in Utilities}

The utility savings is estimated assuming that a $1 \times 10^{6} \mathrm{Btu} / \mathrm{hr}$ loss from the kiln and mix chamber (at a lower kiln temperature) results in a firing rate of $10 \times 10^{6} \mathrm{Btu} / \mathrm{hr}$ at 1 million Btu per $1,000 \mathrm{scfm}$ natural gas, the cost of this rate is $=10 \times 10^{3}$ SCFM $\times \frac{\$ 4.06}{10^{3} \text { SCFM }}=\$ 40 / \mathrm{hr}$ Assume the kiln is operated at temperature (when waste is fed) $66 \%$ of the year: 


$$
\frac{\$ 40}{h r} \times \frac{365 \text { days }}{\text { year }} \times \frac{24 h r}{d a y} \times 66 \%=\$ 231,264 / y r
$$

Total savings $=\$ 4,390+\$ 75,525+\$ 12,970+\$ 231,264=\$ 324,149 /$ year .

\section{Option No. 2-Drum Reuse}

\section{Change in Raw Material}

This option proposes reusing the drums that waste feed was stored in for ash and/or waste storage. Because the ash from soil has nearly the same bulk density as the soil, the ash will require as many drums. This option reduces the disposal of the 1,735 drums. The purchase savings is estimated to be:

$$
\frac{1735 \text { drums }}{\text { year }} \times \frac{\$ 30.75}{\text { drum }}=\frac{\$ 53,351}{\text { year }} \text { (savings in new drum purchase) }
$$

The total number of drums estimated from the incineration of TSCA generated waste for 1994 was 235 drums (see discussion in Section 4.1.2). The estimated number of drums from new FY 1996 solid waste feeds based on the solid waste feed target is 1,000,000 lbs for FY 1996, and assuming an average bulk density of $90 \mathrm{lb} / \mathrm{ft}^{3}$ and $7.35 \mathrm{ft}^{3}$ per 55 gal drum, the number of drums is:

$$
\frac{1,000,000 \mathrm{lb}}{\text { year }} \times \frac{f t 3}{90 \mathrm{lb}} \times \frac{d r u m}{7.35 f t 3}=1,511 \text { drums, say } 1,500 / \text { year }
$$

The total drums for FY 1996 is estimated to be: 235 from incineration of TSCA waste plus 1,500 empty drums from new solid waste feeds $=1,735$ drums.

\section{Change in Disposal}

$$
\frac{1735 \text { drums }}{\text { year }} \times \frac{18 \mathrm{~kg}}{\text { drum }}=\frac{31,230 \mathrm{~kg}}{\text { year }} \text { (mass reduction) }
$$

Based on a disposal cost of $\$ 4.85 / \mathrm{kg}$ at SEG,

$$
\frac{31,230 \mathrm{~kg}}{\text { year }} \times \$ 4.85 / \mathrm{kg}=\$ 151,465 / \text { year }
$$

Total savings $=\$ 53,351+\$ 151,465=\$ 204,816 /$ year. No cost for washing the drums for reuse was available. 


\section{E-12}

\section{Option No. 3-Carbon Recycle}

Assume carbon regenerated in TSCA incinerator

Annual generation rate: $5,452 \mathrm{~kg} /$ year (1994)

Reuse carbon four times before disposal

Virgin carbon cost $=\$ 2.20 / \mathrm{kg}$

Disposal cost (Envirocare): $\$ 6 / \mathrm{kg}$

Average mass of waste drums at TSCA Incinerator in 1994: $73 \mathrm{~kg} / \mathrm{drum}$

$$
\frac{\$ 60}{f^{3}} \times \frac{7.35 f^{3}}{d r u m} \times \frac{1 d r u m}{73 \mathrm{~kg}}=\$ 6 / \mathrm{kg}
$$

Development cost: $\$ 20,000$ (recycle plan, etc.)

Change in raw materials:

$$
5,452 \mathrm{~kg} \times 80 \% \text { reduction } \times \frac{\$ 2.20}{\mathrm{~kg}}=\$ 9,596 \text { annual savings }
$$

Change in disposal:

$$
4,362 \mathrm{~kg} \times \$ 6 / \mathrm{kg}=\$ 26,170 \text { annual savings }
$$

Reduction in reportable waste $=4,362 \mathrm{~kg} /$ year ( $80 \%$ of annual total)

Total savings $=\$ 9,596+\$ 26,170=\$ 35,766 /$ year . 
E-13

\section{Sump Operations Cost Estimates}

\section{Option No, 1-Kiln and SCC Camera Water}

Implementation Costs:

Purchased Equipment

$\$ 1,950$ from page A-2 Material Total cost

Installation

$\$ 6,283$ from page A-2 Labor Total cost

Engineering

$\$ 3,129$ from page A-2 LMES K-25 Engineering

Development

Balance of $\$ 12,000$ cost $=\$ 12,000-\$ 1,950-\$ 6,283-\$ 3,129=\$ 638$

\section{Operating Cost}

Assume 3 gpm savings in TSCA wastewater

$$
3 \mathrm{gal} / \mathrm{min} \times \frac{60 \mathrm{~min}}{\mathrm{hr}} \times \frac{8000 \mathrm{hrs}}{y e a r}=\frac{1,440,000 \mathrm{gal}}{y e a r}=\frac{5,452,363 \mathrm{~kg}}{\text { year }}=\frac{5,452,000 \mathrm{~kg}}{\text { year }}
$$

Analytical cost for TSCA wastewater $=\$ 1$ per 30 gallons

Analytical cost savings $=1,440,000$ gallons/year $\div 30$ gallons $=\$ 48,000 /$ year

Make-Up Water saving of $\$ 2.43 / 1000$ gallon is:

$=1,440,000$ gallons $\times \frac{\$ 2.43}{1000 \text { gallon }}=3499 \approx \frac{\$ 3500}{\text { year }}$

Disposal savings $\$ .048 \mathrm{~kg} \times 5,452,000 \mathrm{~kg}=\$ 261,696$

Total savings $=\$ 48,000+\$ 3,500+\$ 261,696=\$ 313,196$

Option No. 2-Ouench Make-Up Water

Implementation Costs:

Installation

Implementation cost based on program change to control logic set point for interlock of allowable natural gas flow rate from 6,000 acfm to a higher value (e.g., 12,000 acfm). 


$$
8 \mathrm{hrs} \times \frac{\$ 50}{\mathrm{hr}}=\$ 400
$$

\section{Development}

Development cost based on field test to jumper current interlock set point and to determine allowable higher nataral gas firing rate that result in a higher quench outlet gas temperature (e.g., $\left.190^{\circ} \mathrm{F}\right)$ at a $35 \mathrm{gpm}$ quench make up water rate.

$$
16 \text { hrs } \times \frac{\$ 50}{h r}=\$ 800
$$

\section{Estimated Waste Reduction}

Estimate waste reduction based on reducing the quench make-up water from $60 \mathrm{gpm}$ to $35 \mathrm{gpm}$ during standby operations when waste is not being incinerated. The estimated standby time is based on two months' scheduled maintenance per year and waste feed during $66 \%$ of the year:

$$
\frac{8760 \mathrm{hr}}{y e a r}-\frac{2 \times 720 \mathrm{hr}}{\text { month }}-0.66\left(\frac{8,760 \mathrm{hr}}{\text { year }}\right)=1,538 \mathrm{hrs} / \mathrm{year} \text { standby }
$$

Estimated wastewater reduction is:

$$
\frac{(60-35) \mathrm{gal}}{\min } \times \frac{60 \mathrm{~min} .}{\mathrm{hr}} \times \frac{1,538 \mathrm{hr}}{\text { year }}=\frac{2,307,000 \mathrm{gal}}{\text { year }}=\frac{8,697,000 \mathrm{~kg}}{\text { year }}
$$

Change in Raw Materials

$$
2,307,000 \text { gallons } \times \frac{\$ 2.43}{1000 \text { gallon }}=\$ 5,606 \text { savings per year }
$$

Change in Disposal

$$
8,697,000 \mathrm{~kg} \times \frac{\$ 0.048}{\mathrm{~kg}}=\$ 417,475 \text { savings per year }
$$

\section{Analytical Cost Savings}

$$
2,307,000 \text { gallons } \times \frac{\$ 1.00}{30 \text { gallon }}=\$ 76,900 \text { analytical savings per year }
$$

Total savings $=\$ 5,606+\$ 417,475+\$ 76,900=\$ 499,981 /$ year 


\section{Option No. 4-Reroute Quench Purge to IWS Sump*}

Installation

Purchase Equipment

From page $A-4$, material cost estimate total $=\$ 9,400$

Installation

From page $A-4$, labor total $=\$ 18,350$ LMES overhead $=\frac{\$ 10,545}{\$ 28,895}$

Engineering

From page A-3, engineering = $\$ 6,400$

$\$ 2,800$

$\$ 9,200$

Administrative

From page A-3, Project Management = $\$ 6,300$

Qther

$\begin{array}{lll}\text { From page A-3, } & \text { Contingency } \\ \text { Escalation } & =\$ 16,000 \\ & =\$ 3,500\end{array}$

$\$ 19,500$

Assume IWS make-up approximately 5-8 gpm during water feeds (66\% of the year) $=5780$ hours/year; at a 5 gpm saving,

$$
\frac{5 \mathrm{gal}}{\min } \times \frac{60 \mathrm{~min}}{\mathrm{hr}} \times \frac{5780 \mathrm{hrs}}{y e a r}=\frac{1,734,000 \mathrm{gal}}{\text { year }}=\frac{6,565,554 \mathrm{~kg}}{\text { year }}
$$

Disposal savings $=6,565,554 \mathrm{~kg} /$ year $\times \$ .048$ per $\mathrm{kg} \quad=\$ 315,147$

Analytical cost savings $=1,734,000 \mathrm{gal} /$ year $\times \$ 1 / 30 \mathrm{gal}=\$ 57,800$

Make-up water savings $=1,734,000 \mathrm{gal} /$ year $\times \$ 2.43 / 1000$ gallons $=\$ 4,214$

Total savings

$=\$ 377,161 /$ year

*Not a recommended option because of expected regulatory delay. 
Option No. 6-Control Algae

Implementation Costs

Purchased equipment (frame plus tarp) $\$ \$ 10,000$

Installation, including anchors

$\$ 5,000$

Engineering

$\$ 5,000$

Development

$\$ 1,000$

Total Implementation

$\$ 21,000$

Operating Costs

Changes in Raw Material

$5,047 \mathrm{~kg}$ carbon generated from firewater sump in 1994.

Assume that reducing algae increases carbon life by $25 \%$.

$5,047 \mathrm{~kg} \times 0.25=1,262 \mathrm{~kg}$ carbon saved

$1,262 \mathrm{~kg} \times \$ 2.20 / \mathrm{kg}=\$ 2,776 /$ year raw material savings

Change in Maintenance

$\$ 1,000 /$ year additional labor

Change in Disposal

$1,262 \mathrm{~kg} \times \$ 6 / \mathrm{kg}=\$ 7,572 /$ year disposal savings

Total Savings: $\$ 2,776-\$ 1,000+\$ 7,572=\$ 9,348 /$ year 


\section{E-17}

\section{Tank/Tanker Operations Cost Estimates}

\section{Option No. 1-Pneumatic Testing}

This option can be accomplished with a vendor coming on site to test tankers.

Assumptions: Three tankers total 14,000 gallons

\section{Testing done once per.year}

Administrative cost to let purchase order: $\$ 1,000$

Change in raw materials (i.e., potable water):

$$
\frac{14,000 \text { gallons }}{\text { year }} \times \frac{\$ 2.43}{1000 \text { gallons }}=\frac{\$ 34.02}{\text { year }}
$$

Change in labor:

$$
\text { Three tests/year } \times \frac{\$ 400}{\text { test }}=\frac{\$ 1200}{\text { year }} \text { (testing vendor) }
$$

Reduction in waste:

$$
\frac{14,000 \mathrm{gal}}{y e a r} \times \frac{4 \mathrm{~kg}}{\text { gal }}=\frac{56,000 \mathrm{~kg}}{\text { year }}
$$

Change in disposal cost: $\frac{56,000 \mathrm{~kg}}{\text { year }} \times \frac{\$ 11.00}{\mathrm{~kg}}=\frac{\$ 616,000}{\text { year }}$

Total savings $=\$ 34.02-\$ 1,200+\$ 616,000=\$ 614,834 /$ year

\section{Option No. 2-Hydrostatic Testing with Waste}

Perform hydrostatic leak/pressure test with waste instead of water. Vendor can provide services on site.

Administrative cost to let purchase order: $\$ 1,000$

Change in raw materials (i.e., potable water):

$$
\frac{14,000 \text { gallons }}{\text { year }} \times \frac{\$ 2.43}{1000 \text { gallons }}=\frac{\$ 34.02}{\text { year }}
$$

Change in labor:

$$
\text { Three tests/year } \times \frac{\$ 400}{\text { test }}=\frac{\$ 1200}{\text { year }} \text { (testing vendor) }
$$

Reduction in waste:

$$
\frac{14,000 \text { gallons }}{\text { year }} \times \frac{4 \mathrm{~kg}}{8 a \mathrm{l}}=\frac{56,000 \mathrm{~kg}}{\text { year }}
$$




\section{E-18}

Change in disposal cost: $\frac{56,000 \mathrm{~kg}}{\text { year }} \times \frac{\$ 11.00}{\mathrm{~kg}}=\frac{\$ 616,000}{\text { year }}$

Total savings $=\$ 34.02-\$ 1,200+\$ 616,000=\$ 614,834 /$ year

\section{Qption No. 3-Decontamination Procedure}

Assume that pressure washing and hydrostatic leak/pressure testing with waste are also implemented.

Administrative cost to let contract: $\$ 1,000$

Change in raw materials (i.e., diesel fuel):

$$
\frac{3 \text { rinses }}{\text { tanker }} \times \frac{600 \mathrm{gal}}{\text { rinse }} \times 3 \text { tankers } \times \frac{4 \mathrm{~kg}}{8 a l}=\frac{21,600 \mathrm{~kg}}{\text { year }}
$$

Cost of diesel fuel: $\$ 0.25 / \mathrm{kg}$

$$
\frac{21,600 \mathrm{~kg}}{\text { year }} \times \frac{0.25}{\mathrm{~kg} .}=\frac{\$ 5400}{\text { year }}
$$

Reportable waste reduction: $21,600 \mathrm{~kg} /$ year (diesel fuel)

Savings in waste disposal: $\frac{21,600}{\text { year }} \mathrm{kg} \times \frac{\$ 11.00}{\mathrm{~kg}}=\frac{\$ 237,600}{\text { year }}$

Total savings $=\$ 5,400+\$ 237,600=\$ 243,000 /$ year

\section{Option No. 7-Pressure Cleaning of Tankers}

Pressure cleaning equipment to be purchased and installed on site: two 600-gallon recirculating tanks

Purchase equipment: $\$ 28,000$ (Tank Cleaning Consultants)

Installation: $\$ 5,000$ (set up equipment)

Materials: $\$ 10,000$

Utility connections (includes electric, firewater): $\$ 30,000$

Engineering: $\$ 30,000$ (design of roof for the unit)

Start-up/Training: $\$ 2,600$

Administrative cost for purchase: $\$ 440$ 


\section{E-19}

Other (testing for $\mathrm{PCB})$ : $\$ 2,700$

Change in utilities: $\$ 10,000 /$ year (rinsewater, electric)

Reportable waste reduction:

Assume 5 (washes and decontaminations)/year/tanker

Assume $66 \%$ reduction in waste (i.e., from 1800 to 600 gallons/event)

$$
\frac{600 \mathrm{gal}}{\text { rinse }} \times \frac{3 \text { rinsies }}{\text { tanker }} \times \frac{3 \text { tankers }}{\text { event }} \times \frac{5 \text { events }}{\text { year }} \times \frac{4 \mathrm{~kg}}{\mathrm{gal}} \times 0.66=\frac{71,280 \mathrm{~kg}}{\text { year }}
$$

Savings in waste disposal: $\frac{71,280 \mathrm{~kg}}{\text { year }} \times \frac{\$ 11.00}{\mathrm{~kg}}=\frac{\$ 784,080}{\text { year }}$

Total savings $=\$ 10,000+\$ 784,080=\$ 794,080 /$ year 


\section{E-20}

\section{TSCA Incinerator Site Operations Cost Estimates}

\section{Option No. 1-Provide Used Equipment Storage}

Purchased Equipment: $\quad 6$ operator boxes $\times \frac{\$ 1,000}{b 0 x}=\$ 6,000$

Installation costs: Assume $\$ 1,000$

Change in Raw Materials: Assume $\$ 20,000$ savings in equipment purchase per year

Change in Labor: Assume increase of $\$ 1,000$ in labor cost each year for equipment handling

Change in disposal:

Assume 33\% reduction in scrap metal generation.

$14,734 \mathrm{~kg}$ metal $/$ year $\times 0.33=4,906 \mathrm{~kg} /$ year reduction in metal.

$4,906 \mathrm{~kg} /$ year $\times \$ 6.00 / \mathrm{kg}=\$ 29,439 /$ year disposal savings.

Future Liabilities: Assume $\$ 1,000$ per year in additional liability.

Total savings $=\$ 20,000-\$ 1,000+\$ 29,439=\$ 48,439 /$ year

\section{Option No. 2-Compactor}

Implementation cost

Purchased Equipment: $\$ 28,880$ Ram Flat 55 with car filter

Installation costs: Assume $\$ 5,000$ to reinforce pad

Utility Connections: Assume \$3,000 for electrical upgrade

Engineering: $\$ 2,000$ LMES

Development: $\$ 2,000$ oversight

Training: Two persons, three days, $\$ 1,880$

Other: Contingency $30 \%, \$ 12,800$

Escalation, $\$ 2,450$

Total estimated implementation cost: $\$ 58,010$

Operating Cost

Change in maintenance: $\$ 2,000 /$ year increase 
Change in labor: 10 weeks; $\$ 20,000 /$ year increase

Reduction in waste:

Assume 10:1 compaction for laboratory waste 50 drums reduced to 5 drums, saving 45 drums/year

$$
\frac{45 \text { drums }}{\text { year. }} \times \frac{18 \mathrm{~kg}}{\text { drum }}=\frac{810 \mathrm{~kg}}{\text { year }}(30 \% \text { reduction in mass of uncompacted waste) }
$$

Cost savings:

$\frac{45 \text { drums }}{\text { year }} \times \frac{\$ 441}{\text { drum }}=\frac{\$ 19,845}{\text { year }}$

Total cost $=\$ 2,000+\$ 20,000-\$ 19,845=\$ 2,155 /$ year

\section{Option No. 5-Plastic Pallets}

Implementation Cost

Purchased Equipment:

Pallets represented 25\% of discarded wood in 1993

Generation of wood in 1994 was $8,736 \mathrm{~kg}$

Assume each pallet weighs $27 \mathrm{~kg}$

$0.25 \times 8,736 \mathrm{~kg} \times \frac{1 \text { pallet }}{27 \mathrm{~kg}}=81$ pallets

81 pallets $\times \frac{\$ 90}{\text { pallet }}=\$ 7,290$ for plastic pallets

\section{Operating Cost}

Change in raw materials:

$$
81 \text { wood palless } \times \frac{\$ 10}{\text { pallet }}=\frac{\$ 810}{y \text { ear }} \text { savings }
$$

Replace $20 \%$ of plastic pallets each year: $\$ 1,458$ cost

Total change in raw materials: $\$ 648$ cost

Change in labor: Assume $\$ 500 /$ year for sorting pallets

Change in disposal: $\quad 2,184 \mathrm{~kg}$ wood $\times \frac{\$ 6}{\mathrm{~kg}}=\$ 13,104$ savings in disposal

Total savings $=\$ 13,104-\$ 648-\$ 500=\$ 11,956 /$ year 


\section{Option No. 12-Purchase Scaffolding}

Implementation Cost

Purchased Equipment: 3 scaffolds, $\$ 5,000$

Operating Cost:

Change in raw materials: Assume cost of wood $\$ 5,000 /$ year savings

Change in disposal:

Assume $75 \%$ of wood discarded is from scaffolding

$$
0.75 \times \frac{8,736 \mathrm{~kg}}{\text { year }} \times \frac{\$ 6}{\mathrm{~kg}}=\frac{\$ 39,312}{\text { year }}
$$

Total savings $=\$ 5,000+\$ 39,312=44,312 /$ year

\section{Option No. 13-Metal Pallets}

Implementation Cost

Purchased Equipment:

Pallets represented 25\% of discarded wood in 1993

Generation of wood in 1994 was $8,736 \mathrm{~kg}$

Assume each pallet weighs $27 \mathrm{~kg}$

$$
0.25 \times 8,736 \mathrm{~kg} \times \frac{1 \text { pallet }}{27 \mathrm{~kg}}=81 \text { pallets }
$$

81 pallets $\times \frac{\$ 100}{\text { pallet }}=\$ 8,100$ for metal pallets

\section{Operating Cost}

Change in raw materials:

$$
81 \text { wood pallets } \times \frac{\$ 10}{\text { pallet }}=\$ 810 / \text { year savings }
$$

Replace $20 \%$ of metal pallets each year: $\$ 1,620$ cost

Total change in raw materials: $\$ 810$ cost

Change in labor: Assume $\$ 500 /$ year for sorting pallets

Change in disposal: $\quad 2,184 \mathrm{~kg}$ wood $\times \frac{\$ 6}{k_{g}}=\$ 13,104$ savings in disposal 


\section{E-23}

Total savings $=\$ 13,104-\$ 810-\$ 500=\$ 11,794 /$ year

\section{Option No, 14-Rental Scaffolds}

Change in labor: $\$ 4,000 /$ year assembly and decontamination reduction cost

Change in Disposal: $6,552 \mathrm{~kg} /$ year wood scaffolding $\times \$ 6 / \mathrm{kg}=\$ 39,312 /$ year savings

Change in raw materials:

$\$ 7,000 /$ year additional cost of renting scaffolds over purchasing wood

Total savings $=\$ 39,312+\$ 4,000-\$ 7,000=\$ 36,312 /$ year 


\section{Distribution}

1. K. E. Amburn

2-5. B. D. Barkenbus

6. J. F. Betschart

7. H. T, Conner, Jr.

8. A. H. Cromwell

9. K. M. Downer

10. J. E. Dunn

11. C. E. Frye

12. W. G. Melton

13. D. R. Moser

14. S. W. Nelson

15. F. Perez

16. J. S. Suffern

17. E. F. Thomas

18. A. E. Walzer

19. H. D. Whitehead, Jr.

20. J. H. Wright

21. WMD Document Center-RC 